\title{
Characterization of olfactory receptor gene expression in the olfactory epithelium of larval Xenopus laevis
}

\author{
PhD Thesis \\ in partial fulfillment of the requirements for the degree \\ "Doctor of Philosophy (PhD)/Dr. rer. nat." \\ in the Neuroscience Program \\ at the Georg August University Göttingen, Faculty of Biology
}

\author{
submitted by \\ Sebastian Gliem \\ born in \\ Rotenburg a.d. Fulda, \\ Germany
}

September

2010 
Herewith I declare that I prepared the PhD Thesis "Characterization of olfactory receptor gene expression in the olfactory epithelium of larval Xenopus laevis" on my own and with no other sources and aids than quoted.

Göttingen, September $20^{\text {th }}, 2010$

Advisor, first member of PhD committee: Prof. Dr. Dr. Detlev Schild Second member of PhD committee: Prof. Dr. Ralf Heinrich Third member of $\mathrm{PhD}$ committee: $\quad$ Prof. Dr. Jürgen Wienands

Date of submission of the PhD thesis: September $20^{\text {th }}, 2010$ 
Für meine Familie 


\section{TABLE OF CONTENTS}

TABLE OF CONTENTS

LIST OF FIGURES

LIST OF TABLES $\quad$ xi

LIST OF ABBREVIATIONS Xiii

ABSTRACT $\quad x v$

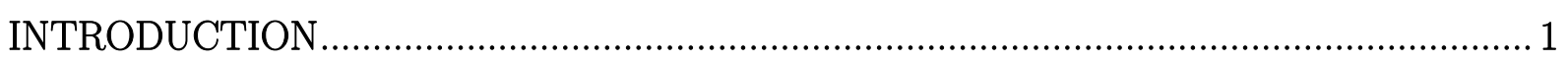

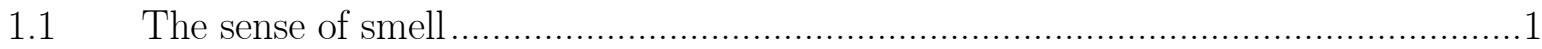

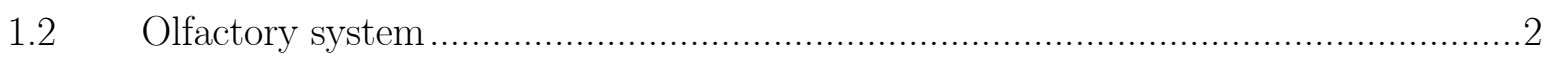

1.2.1 Functional organisation of the main olfactory system ….................................2

1.2.2 Signal transduction mechanisms in ORNs.....................................................

1.2.3 Transformation of receptor potentials .............................................................

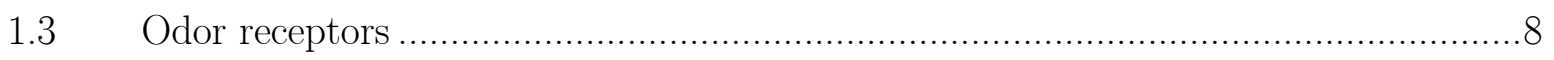

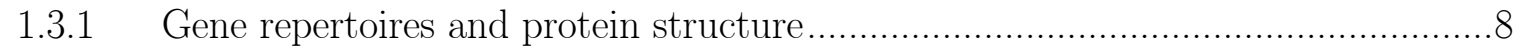

1.3.2 Genomic organisation of OR genes ...................................................... 10

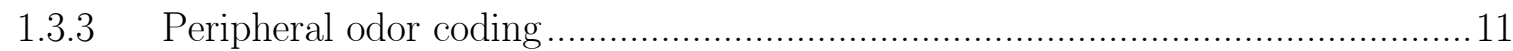

1.4 The one receptor-one neuron hypothesis revisited ........................................... 13

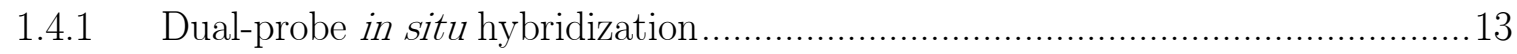

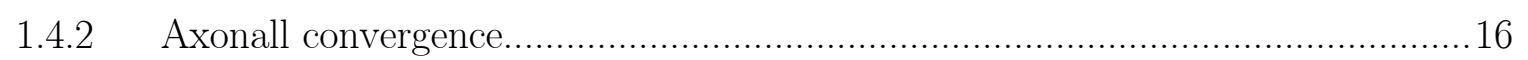

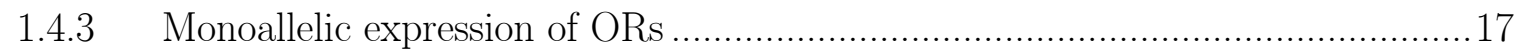

1.4.4 Positive and Negative feedback regulation of OR gene expression .....................18

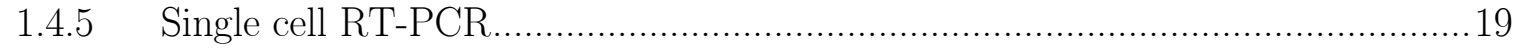

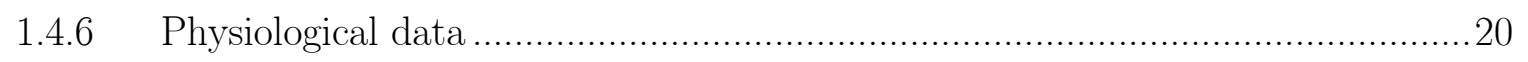

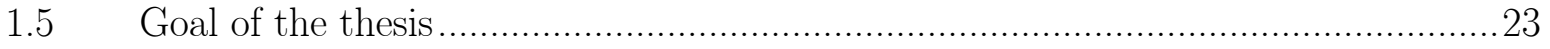

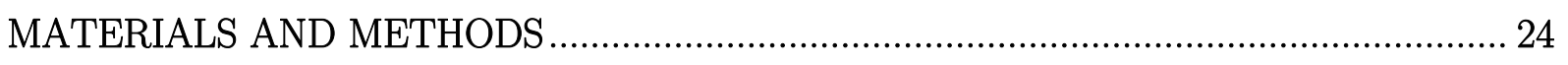

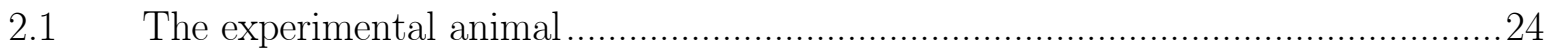

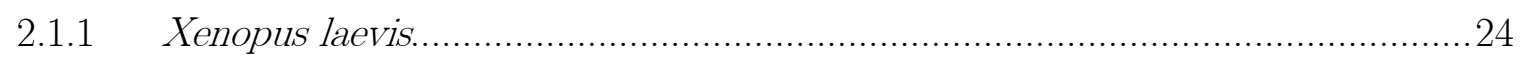


2.1.2 Organisation and development of the olfactory system in Xenopus

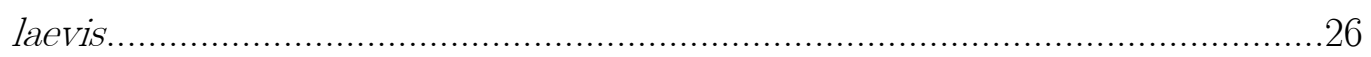

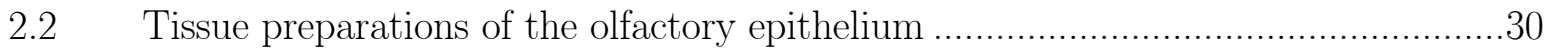

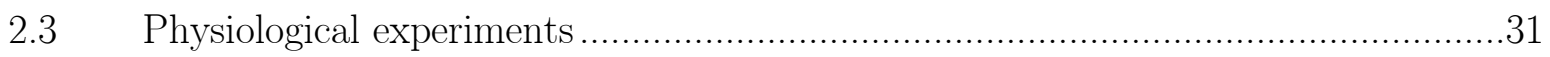

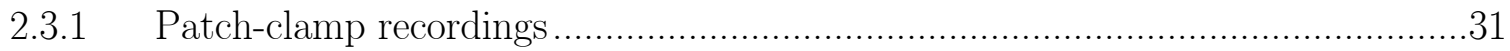

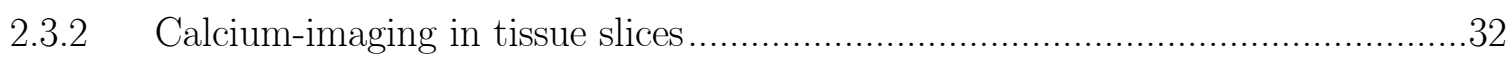

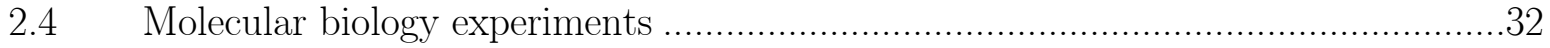

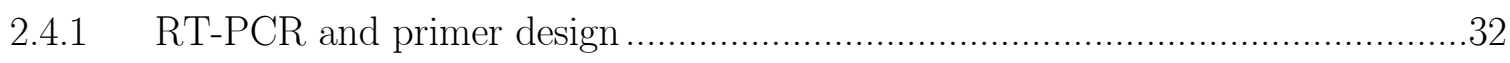

2.4.2 RT-PCR assay using tissue of the olfactory organ ........................................

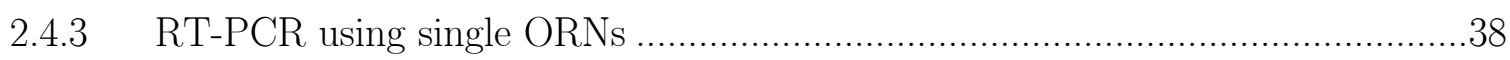

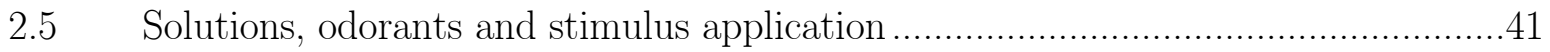

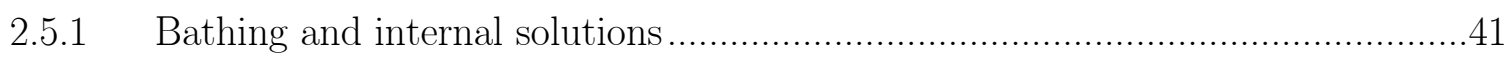

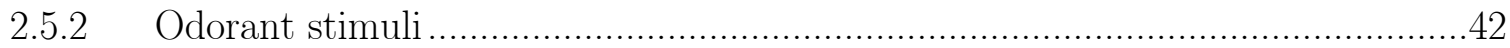

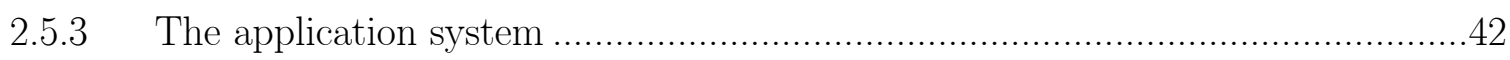

2.6 Immunostaining of the olfactory epithelium and olfactory bulb .........................44

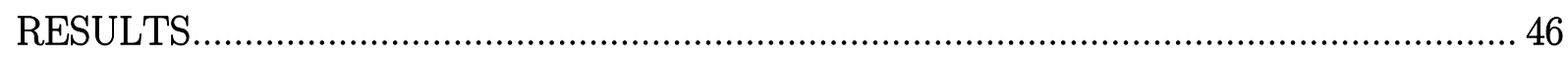

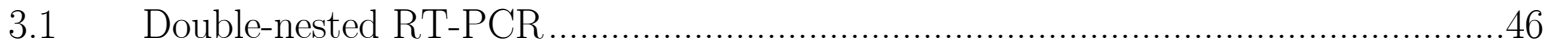

3.2 Expression of chemoreceptors in the olfactory epithelium of Xenopus

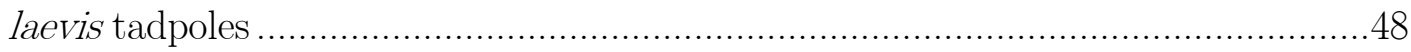

3.3 Expression of multiple receptors in single receptor neurons.................................49

3.3.1 Patch-clamp measurements of single ORNs ...................................................49

3.3.2 Simultaneous expression of multiple ORs in individual ORNs .........................50

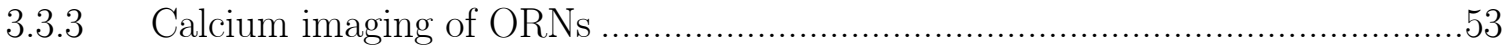

3.3.4 RT-PCR analysis of preimaged ORNs.................................................. 54

3.4 Deorphanisation of expressed chemoreceptors ..................................................5

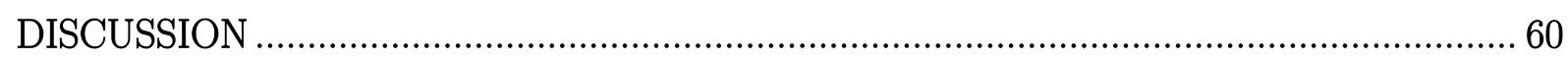

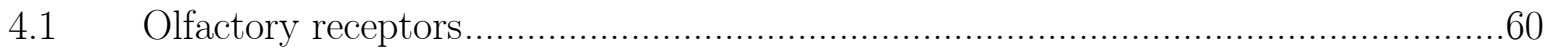

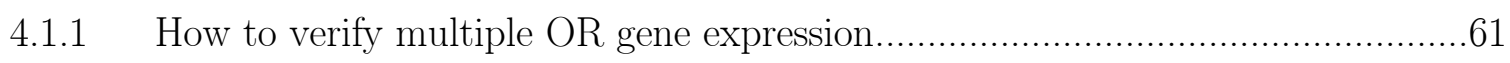

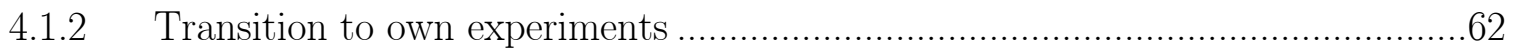


4.2 Evaluation of the applied method

4.3 Olfactory and vomeronasal receptors are expressed in larval olfactory tissue 66

4.4 Multiple receptors are expressed in single ORNs ................................................67

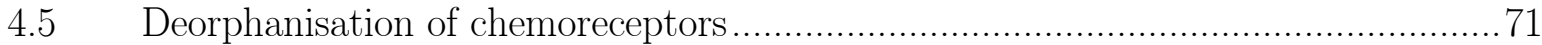

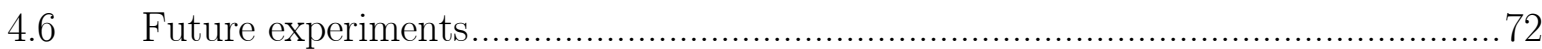

$\begin{array}{ll}\text { SUMMARY } & 74\end{array}$

$\begin{array}{ll}\text { REFERENCES } & 76\end{array}$

SUPPLEMENTARY FIGURES 94

ACKNOWLEDGEMENTS 98

$\begin{array}{ll}\text { CURRICULUM VITAE } & 100\end{array}$

LIST OF PUBLICATIONS 


\section{LIST OF FIGURES}

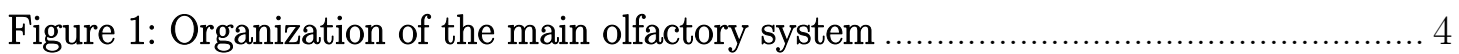

Figure 2: cAMP-dependent olfactory transduction in ORNs. ............................... 5

Figure 3: Predicted structure of an olfactory receptor ....................................... 9

Figure 4: Genomic organization of olfactory receptor genes................................... 11

Figure 5: The combinatorial code of olfaction ................................................... 12

Figure 6: Patterns of olfactory receptor expression in rat..................................... 14

Figure 7: Coexpression of multiple ORs in single ORNs of zebrafish ....................... 15

Figure 8: Bulbar patterns of olfactory receptor expression in rat ........................... 17

Figure 9: A model for OR gene expression. ....................................................... 19

Figure 10: Crossadaptation of amino acid-sensitive ORNs …................................ 22

Figure 11: Xenopus laevis tadpole (stage 52) ................................................... 25

Figure 12: Immunohistochemical staining of the OE of Xenopus laevis larvae. ......... 28

Figure 13: Immunohistochemical staining of the OB of Xenopus laevis larvae. ......... 29

Figure 14: Chemical structure of Fluo-4/AM........................................................ 30

Figure 15: Schematic drawing of the application system ......................................... 43

Figure 16: Reverse transcription and double nested PCR ...................................... 47

Figure 17: Identification of OR and V1R mRNA in the olfactory organ .................. 48

Figure 18: Patch-clamp recordings from a single ORN ........................................... 49

Figure 19: Expression of multiple ORs per single ORN ........................................ 51

Figure 20: Frequency of OR-expression in single ORNs......................................... 52

Figure 21: Rate of expressed OR per ORN. ....................................................... 52

Figure 22: Calcium imaging and cell harvesting.................................................. 53

Figure 23: Frequency of OR-expression in preimaged ORNs …............................. 55

Figure 24: Rate of expressed ORs per preimaged ORN …................................. 56

Figure 25: Expression of multiple ORs in a preimaged ORN ................................ 57

Figure 26: Model of OR-expression in Xenopus laevis .......................................... 70 


\section{LIST OF TABLES}

Table 1: List of all chemoreceptors tested in this study .................................... 34

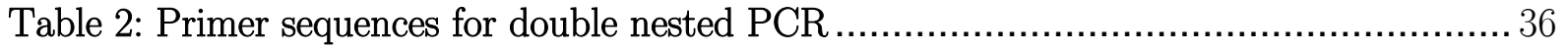

Table 3: Composition of bath and internal solutions ......................................... 41

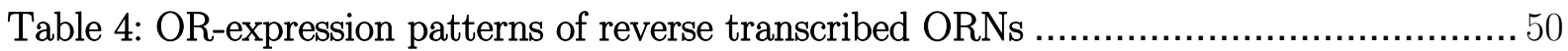

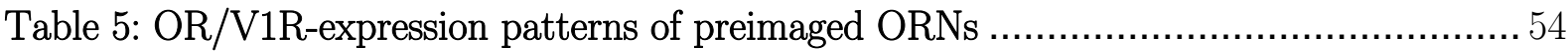

Table 6: Response profiles of expressed chemoreceptors......................................59 


\section{LIST OF ABBREVIATIONS}

$\begin{array}{ll}\text { ATP } & \text { Adenosine triphosphate } \\ {\left[\mathrm{Ca}^{2+}\right]_{i}} & \text { Intracellular } \mathrm{Ca}^{2+} \text { concentration } \\ \text { cAMP } & \text { Cyclic adenosine monophosphate } \\ \text { cDNA } & \text { complementary DNA } \\ \text { cGMP } & \text { Cyclic guanosine monophosphate } \\ \text { CNG } & \text { Cyclic nucleotide-gated } \\ \text { Deg. } & \text { Degenerate } \\ \text { DMSO } & \text { Dimethyl sulfoxide } \\ \text { EGTA } & \text { Ethylene glycol tetraacetic acid } \\ \text { gDNA } & \text { genomic DNA } \\ \text { Golf } & \text { Olfactory-specific guanosine triphosphate (GTP)-binding protein } \\ \text { GTP } & \text { Guanosine triphosphate } \\ \text { HEPES } & \text { 4-(2-hydroxyethyl)-1-piperazineethanesulfonic acid } \\ \text { NGS } & \text { Normal goat serum } \\ \text { OE } & \text { Olfactory epithelium } \\ \text { ON } & \text { Olfactory nerve } \\ \text { OR } & \text { Olfactory receptor } \\ \text { ORN } & \text { Olfactory receptor neuron } \\ \text { PBS } & \text { Phosphate-buffered saline } \\ \text { PBST } & \text { PBS containing 0.2\% Triton X-100 } \\ \text { PCR } & \text { Polymerase chain reaction } \\ \text { PFA } & \text { Paraformaldehyde } \\ \text { RT } & \text { Reverse transcription } \\ \text { RT-PCR } & \text { Reverse transcription polymerase chain reaction } \\ \text { V1R } & \text { Vomeronasal receptor type 1 } \\ \text { VNO } & \text { Vomeronasal organ } \\ \text { X.l. } & \text { Xenopus laevis } \\ \text { X.t. } & \text { Xenopus tropicalis } \\ & \end{array}$

Abbreviations exclusively used in figures are explained in the respective figure legends. 


\begin{abstract}
Olfactory receptors comprise the largest multigene family of $\mathrm{G}$ protein-coupled receptors in organisms ranging from fish to primates and are the detectors of thousands of odorant molecules. As they are crucial elements for odor recognition, much effort was put into the analysis of how olfactory receptor neurons express olfactory receptor genes and how odorant information is encoded by the receptor proteins. It is nowadays expected that each olfactory receptor neuron expresses only a single odorant receptor gene and that each receptor can be activated by multiple stimuli. According to this, a combinatorial code for odor detection was proposed to explain peripheral coding of odorant stimuli in the olfactory system. However, some mostly recent studies point towards a revision of this scheme, especially with regard to the one receptor-one neuron hypothesis. Consequently, this thesis aims to investigate this discrepancy. In order to answer whether a single or multiple olfactory receptors are expressed in single olfactory receptor neurons of Xenopus larvae, a single cell reverse transcription PCR protocol was developed. The obtained data propose, that, at least during the developmental phase of Xenopus, a subset of olfactory receptor neurons exists exhibiting oligogenic expression of olfactory receptors. In addition to this straight expression assay, ligand-sensitivities of olfactory receptors were characterized. In order to retrospectively identify receptors that recognize a particular odorant of interest, an assay was established that combined $\mathrm{Ca}^{2+}$ imaging and single cell reverse transcription PCR. Expressed transcripts of olfactory receptor genes were thereby amplified from those olfactory neurons that showed odorant responsiveness to certain amino acids. This functional strategy led to the finding of one candidate receptor that may be sensitive to these stimuli.
\end{abstract}





\section{1 \\ INTRODUCTION}

\subsection{The sense of smell}

"Jemand der den Duft einer Rose nicht riecht wird doch nicht darueber kritisieren duerfen; und riecht er ihn, à la bonne heure!

Dann wird ihm die Lust vergehen zu kritisieren.”

Friedrich Nietzsche (1844-1900)

If humans were asked to rank the five sensory senses according to today's relevance, the sense of smell would probably finish last or at most second to last. This is understable since today's society is strongly conditioned on visual and auditory attractions. However, olfactory cues are nowadays still significant sensory input signals and are not solely used for the appreciation of food platability and initiation of food intake (Rolls, 2005; Yeomans, 2006). Odors also interfere or even manipulate emotional responses, e.g. joy and fear, and social behaviors, e.g. recognition of conspecifics and mating partners (Schultz and Tapp, 1973; Nimmermark, 2004; Takahashi et al., 2005).

The influence of scents is often not realized until the absence of olfaction. Patients with impairments in odor recognition suffer because of a decrease in their life quality. They eventually perceive personal isolation or simply feel a lack of interest in things they enjoyed before. Next to studies which showed that depression is associated to disorders in olfaction (Toller, 1999; Lombion-Pouthier et al., 2006; Nordin and Brämerson, 2008), recent publications pointed out that a dysfunction of olfaction can be regarded as one of the first symptoms of neurodegenerative and cognitive diseases like Parkinsons, Alzheimers or Huntingtons disease (Lazic et al., 2007; Doty, 2008; Doty, 2009).

All these examples illustrate the often unnoticed and unacknowledged importance of the sense of smell. 


\subsection{Olfactory system}

"The most beautiful thing we can experience is the mysterious.

It is the source of all true art and all science."

Albert Einstein (1879-1955)

Olfaction is one of the most ancient senses of organisms and aims to detect and discriminate between a huge variety of odorant molecules with a great sensitivity. However, only little research was conducted in this field until the last quarter of the $20^{\text {th }}$ century. But when a large family of olfactory receptor proteins was discovered at the beginning of the 90ths, research became more and more popular. Investigations were eventually rewarded by the nobel-prize in Physiology or Medicine, which was given to Linda Buck and Richard Axel in 2001. Although quite some progress was made until now, the olfactory system is probably still the least understood sensory system.

\subsubsection{Functional organisation of the main olfactory system}

In vertebrates the main olfactory system (see Figure 1) can roughly be divided into three major parts, namely the olfactory epithelium (OE), the olfactory bulb (OB) and higher brain centers. The OE is located in the nasal cavity and covered by a layer of mucus, which is produced and secreted by sustentacular cells and by the bowman's glands (Getchell, 1986; Schild and Restrepo, 1998; Gold, 1999; Schwob, 2002). It consists of three basic kinds of cells, olfactory receptor neurons (ORNs), sustentacular cells and basal cells.

Olfactory receptor neurons are bipolar neurons that transduce and transform olfactory information. Their single dendrites extend to the nasal cavity and end in knobs bearing cilia or microvilli on which olfactory receptors are located. These detect odorant molecules which are either present in the terrestrial or aquatic environment of the species. At the basal side of the soma an unbranched, unmyelinated axon originates and projects via the olfactory nerve to the olfactory bulb (Getchell, 1986; Schild and Restrepo, 1998; Gold, 1999). The olfactory information is thereby transmitted by a sequence of action potentials. 
Sustentacular cells are supportive cells and are either secretory or bear cilia. Their somata are located at the apical side of the OE. Sustentacular cells have multiple functions and share common features with glia. Their principal tasks are the electrical insulation between the ORNs (Breipohl et al., 1974; Getchell and Getchell, 1992) and the production as well as regulation of mucus secretion (Getchell and Getchell, 1992; Hansen et al., 1998). In addition it was suggested that they also play a role in detoxification processes as they contain detoxifying enzymes, like UDP glucuronosyl transferase (Lazard et al., 1991). Recent studies reported a role of sustentacular cells in purinergic signaling within the OE (Hegg and Lucero, 2006; Hassenklöver et al., 2008; Hassenklöver et al., 2009) and showed that these cells are involved in the modulation of odor sensitivity by an endocannabinoid system (Breunig et al., 2010).

Basal cells are precursors of ORNs and supporting cells. Due to a constant exposure of the OE to a variety of cytotoxic substances in the environment and the resulting cellular damage, ORNs and SCs need to be replaced throughout lifetime. By their potential to differentiate into ORNs and sustentacular cells, basal cells are indispensible elements for the maintenance of the OE (Ronnett and Moon, 2002; Schwob, 2002). Recently purinergic signaling was shown to be a triggering mechanism for the activation and proliferation of basal cells (Hassenklöver et al., 2009; Jia et al., 2009; Jia et al., 2010).

Odorant information is transmitted via the olfactory nerve to the $\mathrm{OB}$, which is the first relay station in the olfactory pathway (Figure 1). The nerve consists of axons from all, mostly mature, ORNs in the OE. After the axons have penetrated the cribiform plate of the skull, they form glutamatergic synapses with dendrites of mitral cells (Berkowicz et al., 1994; Firestein, 2001; Munger et al., 2009). These synapses are located in specialized structures called glomerula. The spatio-temporal patterns of glomerular activity represent the olfactory information (Wachowiak and Shipley, 2006; Junek et al., 2010). On the level of mitral cells two types of interneurons, namely periglomerular and granule cells, are involved in the odor processing, which is modulated by local inhibitory circuits (Nezlin and Schild, 2000). The axons of the mitral cells leave the $\mathrm{OB}$ via the lateral olfactory tract and convey the output signals to higher cerebral structures, mainly to the olfactory cortex and associated fields (Mori et al., 1999; Nezlin and Schild, 2000; Lledo et al., 2005; Wilson and Mainen, 2006). 


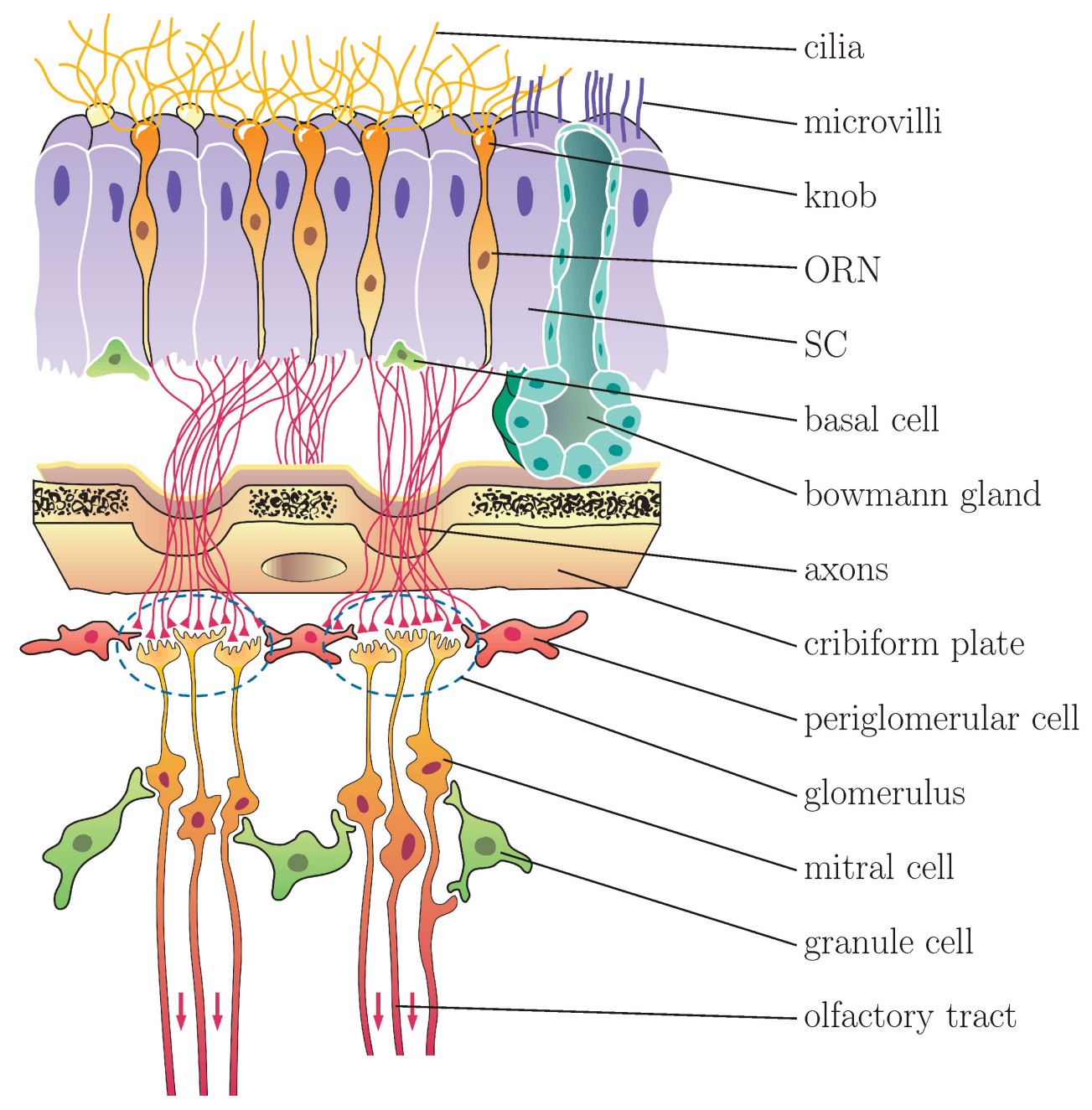

Figure 1: Organization of the main olfactory system. The sketch illustrates the morphology of the olfactory system. Abbreviations: ORN, olfactory receptor neuron; SC, sustentacular cell. Figure modified after Lang and Lang (2007); In "Basiswissen Physiologie", page 429; $2^{\text {nd }}$ edition; Springer Berlin Verlag.

\subsubsection{Signal transduction mechanisms in ORNs}

Once an odorant molecule has bound to an olfactory receptor a cascade of intracellular events is initiated (Figure 2). First, odorant-bound ORs activate a G protein, which is an olfactory-specific subtype, $\mathrm{G}_{\text {olf }}$ (Jones and Reed, 1989). The GTPbound $\alpha$-subunit dissociates from the $\beta \gamma$-subunits and leads to the activation of 
adenylyl cyclase type III. The enzyme in turn converts intracellular ATP into cyclic AMP (cAMP), which directly gates an ion channel (cyclic nucleotide-gated (CNG) channel; Nakamura and Gold, 1987; Dhallan et al., 1990; Frings et al., 1992) permeable for cations including $\mathrm{Ca}^{2+}$ and $\mathrm{Na}^{+}$(Firestein et al., 1991). The rise in intracellular $\mathrm{Ca}^{2+}$ subsequently opens $\mathrm{Ca}^{2+}$-activated $\mathrm{Cl}^{-}$channels leading to a $\mathrm{Cl}^{-}$ efflux as ORNs maintain a high intracellular $\mathrm{Cl}^{-}$concentration (Kleene and Gesteland, 1991; Kleene, 1993; Firestein and Shepard, 1995; Kleene, 2008). The odor-induced electrical response can thereby be distinguished into an initial compound by cationic influx and into the $\mathrm{Cl}^{-}$efflux, which further depolarizes the cell by adding to the excitatory response magnitude. The direct actions of the second messenger cascade and of $\mathrm{Ca}^{2+}$-ions are therefore both providing amplification and eventually integration of the odor information. Following membrane depolarization the receptor potential electrotonically propagates to the axon hillock and eventually initiates a sequence of action potentials.

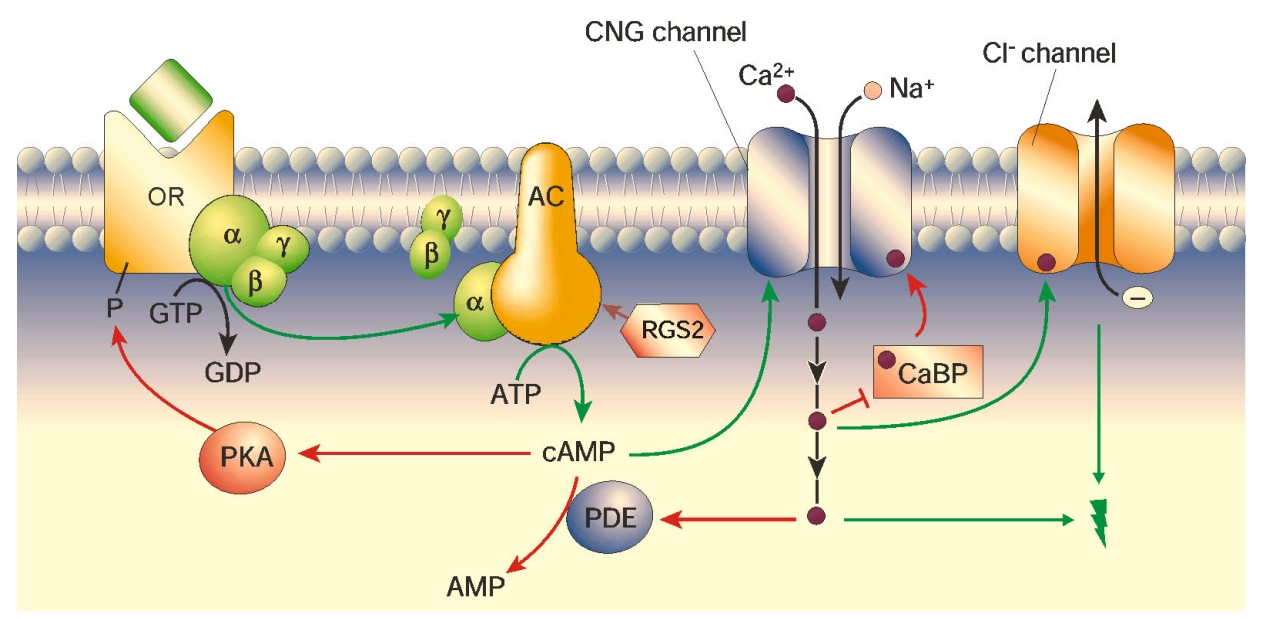

Figure 2: cAMP-dependent olfactory transduction in ORNs. Following the detection of an odorant molecule (green square) by an olfactory receptor (OR) on the cilia, a G-protein mediated transduction cascade is iniated. This leads to a gating of CNG channels by cAMP and subsequently to an opening of $\mathrm{Ca}^{2+}$-dependent $\mathrm{Cl}^{-}$channels. Influx of $\mathrm{Na}^{+}$and $\mathrm{Ca}^{2+}$ as well as efflux of $\mathrm{Cl}^{-}$ions are the final steps for the depolarization of the membrane (green arrows). To (re-) adjust their sensitivity ORNs use several mechanisms (red arrows) that involve $\mathrm{Ca}^{2+}$-binding proteins $(\mathrm{CaBP})$, phosphodiesterases (PDE) and protein kinases. Further abbreviations: protein kinase A (PKA); adenylyl cyclase (AC); regulator of Gprotein signaling type 2 (RGS2). Figure modified after Firestein (2001). 
In addition to the depolarizing effect, $\mathrm{Ca}^{2+}$-ions were reported to have the reverse effect on the $\mathrm{CNG}$ channels, probably in combination with $\mathrm{Ca}^{2+}$-binding proteins like calmodulin (Kurahashi and Menini, 1997; Trudeau and Zagotta, 2003; Bradley et al., 2004). Thereby $\mathrm{Ca}^{2+}$ causes a decrease in CNG channel sensitivity to cAMP. By this, stronger odor stimuli are required to produce sufficient cAMP to (re-) open the channel (Kramer and Siegelbaum, 1992; Chen and Yau, 1994; Liu et al., 1994). This adaptation response is necessary as ORNs would otherwise only be able to respond over a narrow dynamic range.

Next to this mechanism ORNs use other negative feedback pathways for adjusting their odor sensitivity. $\mathrm{Ca}^{2+}$, for instance, also activates a cyclic nucleotide phosphodiesterase that degrades the phosphodiester bond in the cAMP molecule thereby creating AMP (Borisy et al., 1992; Yan et al., 1995). In addition $\mathrm{Ca}^{2+}$ was also shown to attenuate adenylyl cyclase activity (Shirley et al., 1986; Leinders-Zufall et al., 1999). Furthermore a regulator of $G$ protein signaling, the protein RGS2, was shown to act on the adenylyl cyclase and decreased its activity (Sinnarajah et al., 2001). Regarding protein kinases it was found that protein kinase A (PKA; Boeckhoff et al., 1992; Boeckhoff and Breer, 1992) and a $\beta$-adrenergic receptor kinase are able to desensitize activated olfactory receptors (Dawson et al., 1993; Schleicher et al., 1993).

Although the described cAMP-dependent transduction cascade appears to be predominant for odorant detection in many species and is well described today, there are also other non-cAMP dependent transduction mechanisms existing (Michel and Ache, 1994; Meyer et al., 2000; Manzini et al., 2002). Previous reports have suggested inositol trisphosphate ( $\mathrm{IP}_{3}$; Fadool and Ache, 1992; Schild et al., 1995; Bruch, 1996; Krieger et al., 1997; Kaur et al., 2001), cyclic GMP (cGMP; Fülle et al., 1995; Juilfs et al., 1997; Zufall and Leinders-Zufall, 1998; Leinders-Zufall et al., 2007), nitric oxide and carbon monoxide (Breer and Shepherd, 1993; Leinders-Zufall et al., 1995; Broillet and Firestein, 1996; Morales and Bacigalupo, 1996; Schild and Restrepo, 1998) being involved in these pathways as second messenger molecules.

In addition to depolarization of ORNs certain odors can however also elicit a hyperpolarizing receptor potential followed by a decrease in action potential frequency (Michel and Ache, 1994; Morales et al., 1994; Morales et al., 1995; Kang and Caprio, 1995; Morales et al., 1997; Vogler and Schild, 1999). Furthermore the possibility of ORNs possessing more than just one transduction pathway should not be excluded. It was shown in lobsters that odorant stimulation can result in either excitatory or inhibitory responses of individual ORNs (Michel and Ache, 1994). Other observations 
reported a cross-talk between the cAMP and $\mathrm{IP}_{3}$ pathway in single ORNs (Chen et al., 2000; Vogl et al., 2000; Ko and Park, 2006).

In summary, the examples present evidence for the existence of a diversity of transduction mechanisms and signaling messengers, which may not only work in parallel but may also work in concert to process complex odorant signals. This indicates that the olfactory system most probably contains numerous subsystems that can be distinguished by the chemostimuli to which they respond, and the chemosensory receptors and other signaling proteins that they express (Ma, 2007; Munger et al., 2009).

\subsubsection{Transformation of receptor potentials}

Owing to the physical properties of being small cells with a high membrane resistance, a long time constant, but a small membrane capacitance (Schild and Restrepo, 1998; Imanaka and Takeuchi, 2001), ORNs can be excited by relatively small currents and are therefore highly sensitive to odorant stimulation. Once the membrane is depolarized, the generated receptor potential electrotonically propagates to the soma of the ORNs. The amplitude of the receptor potential correlates to the number of molecules that have bound to the olfactory receptors. If such a potential causes the membrane potential to become about $20 \mathrm{mV}$ less negative than the resting potential, the cell will reach threshold. Voltage-gated $\mathrm{Na}^{+}$channels are activated and open at the site of the axon hillock, thereby initiating action potentials (Schild, 1989). These are then conveyed towards the $\mathrm{OB}$ via the axon. Subsequently this strong depolarization electrotonically propagates back from the axon hillock to the soma and the proximal dendrite. There it will activate voltage-gated $\mathrm{Ca}^{2+}$ channels. The following $\mathrm{Ca}^{2+}$ influx causes $\mathrm{Ca}^{2+}$-dependent $\mathrm{K}^{+}$channels to open. Together with activated voltage-gated $\mathrm{K}^{+}$channels at the axon hillock, the total $\mathrm{K}^{+}$efflux serves to repolarise the cell membrane and leads to a termination of action potential initiation (Schild, 1989; Schild et al., 1994). 


\subsection{Odor receptors}

"A man of genius makes no mistakes. His errors

are volitional and are the portals of discovery."

James Joyce (1882-1941)

Odor receptors are proteins that are located on cilia/microvilli of olfactory receptor neurons. Activation of these proteins is induced upon odorant binding and determines which cells become excited and which activity patterns are generated in the olfactory bulb. In addition to this class of receptors another class of chemoreceptors was shown to be expressed by olfactory receptor neurons of human, goat and frog: vomeronasal receptors type 1 (Rodriguez et al., 2000; Rodriguez and Mombaerts, 2002; Wakabayashi et al., 2002; Date-Ito et al., 2008). Since vomeronasal receptors respresent their own and complex topic, they are not dealt with more in greater detail here (for reviews see Brennan, 2001; Zufall et al., 2002; Niimura and Nei, 2006; Zufall and Leiders-Zufall, 2007).

\subsubsection{Gene repertoires and protein structure}

Almost two decades ago the discovery of the mammalian family of olfactory receptors (ORs; Buck and Axel, 1991) produced an astonishing result. The identification of as many as 1000 OR genes made this multigene receptor family the largest family of G protein-coupled receptors (GPCRs) and eventually even the largest gene family in the whole genome. It is proposed that mice have about 1000 different functional ORs (Young et al., 2002; Zhang and Firestein, 2002; Godfrey et al., 2004; Zhang et al., 2004; Niimura and Nei, 2005b) and that humans have about 350 (Glusman et al., 2001; Zozulya et al., 2001; Malnic et al., 2004; Niimura and Nei, 2005b). In frogs the existence of about 400 functional OR genes was predicted (Niimura and Nei, 2005a) while in fish only about 50-100 functional OR genes were proposed (Ngai et al., 1993; Barth et al., 1996; Weth et al., 1996; Niimura and Nei, 2005a). For fish it was hypothesized that the rather low amount of OR genes is probably due to a relatively limited number of water-soluble molecules which the animals can sense (Freitag et al., 1998). This hypothesis could be supported by the fact that the fish OR gene family is much more diverse than in the other species (Niimura and Nei, 2005a), which may 
imply that fish rather sense groups of odors but can probably not so intensively differentiate between the specific compounds compared to other species.

Regarding the total number of OR genes in the genomes of the mentioned species it was found that there are 25-60\% pseudogenes (Niimura and Nei, 2005a,b) which are defunctional relatives of known OR genes that have lost their proteincoding ability. Nonetheless this finding appears to be remarkable as it opens a discussion about the evolution and relevance of ORs in the different species (Niimura and Nei, 2005b).

The coding region of vertebrate ORs is intronless, a structure that predicts seven $\alpha$-helical membrane-spanning domains, which are connected by intra- and extracellular loops (Figure 3). According to the variability within the transmembrane domains (TMDs), especially in the third, fourth and fifth, it was proposed that they might function as the ligand-binding site, similar to other GPCRs (Ngai et al., 1993; Pilpel and Lancet, 1999; Singer et al., 1995; Singer, 2000; Firestein, 2001). However more recent studies predicted that amino acids of TMD 3, TMD 5 and TMD 6 form the pocket for odor binding (Katada et al., 2005; Abaffy et al., 2007). Despite the depicted variability there are also certain conserved characteristics, such as a long second extracellular loop and a short third intracellular one (Figure 3). Regarding the helical structure of the intracellular C-terminal domain it was suggested that this is essential for the interaction between ORs and G proteins (Katada et al., 2005; Kato et al., 2008).
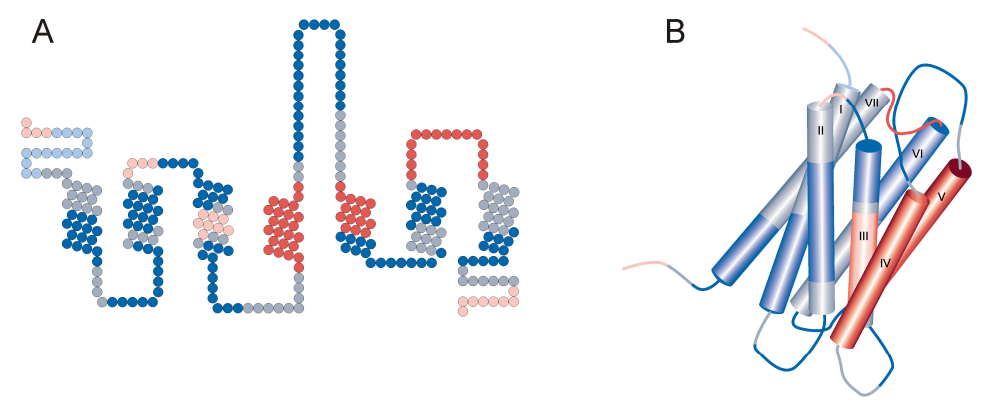

Figure 3: Predicted structure of an olfactory receptor. Comparison of OR sequences across mammalian odor receptors revealed many conserved but also variable regions. Conserved amino acid residues are shown in shades of blue, variable ones in shades of red. (A) The diagram of the mouse odorant receptor M71 shows the seven $\alpha$-helical regions, which are connected by intra- and extracellular loops. (B) Based on the structure of the G proteincoupled receptor rhodopsin this schematic view represents a proposed three-dimensional structure of the M71 receptor. Figure modified after Firestein 2001. 


\subsubsection{Genomic organisation of OR genes}

On average OR genes are about 310 codons long and reside in genomic clusters that seem to be scattered throughout the genome. Regarding these clusters it was found that up to 100 OR genes can be contained in one gene locus with up to 100 clusters dispersed in the genome (Figure 4; Glusman, 2001; Young et al., 2002; Zhang and Firestein, 2002; Godfrey et al., 2004; Zhang et al., 2004). It is noteworthy that nonOR genes are usually excluded from these clusters (Glusman et al., 2001). Altogether, OR clusters may occupy 1-3\% of the mammalian genome, which is a large territory for just one gene family (Glusman, 2001; Firestein, 2004).

For each species the OR gene family is considered to reflect the species-specific ability to detect scents of the respective terrestrial or aquatic environment. More than a decade ago it was shown and also accepted that vertebrate ORs can be classified into two different groups, namely class I and class II genes (Freitag et al., 1995; Glusman et al., 2000). From the observation that Xenoups laevis expresses class I genes exclusively in the water-filled lateral diverticulum and class II genes in the airfilled medial diverticulum of the nasal cavities it has been concluded that class I ORs are specialized for the detection of water-soluble odorants whereas class II ORs detect airborne odors (Freitag et al., 1995; Mezler et al., 2001). Accordingly, class I genes were referred to as 'aquatic-like' genes while 'terrestrial-like' ones are believed to belong to class II genes. However, following research on the mouse and human genome revealed the existence of several functional class I OR genes, which illustrates that the functional difference between both receptor classes is still unclear (Glusman et al., 2001; Zozulya et al., 2001; Zhang and Firestein, 2002; Malnic et al., 2004). Moreover, recent studies in mice showed that class I and class II expressing neurons determine glomerular mapping in the dorsal olfactory bulb (Tsuboi et al., 2006; Kobayakawa et al., 2007) and that these class-specific anatomical domains correlate with known functional odorant response domains (Bozza et al., 2009). An explanation might be that odorants being present in water or in air are both recognized by the class I receptors (Kratz et al., 2002). 


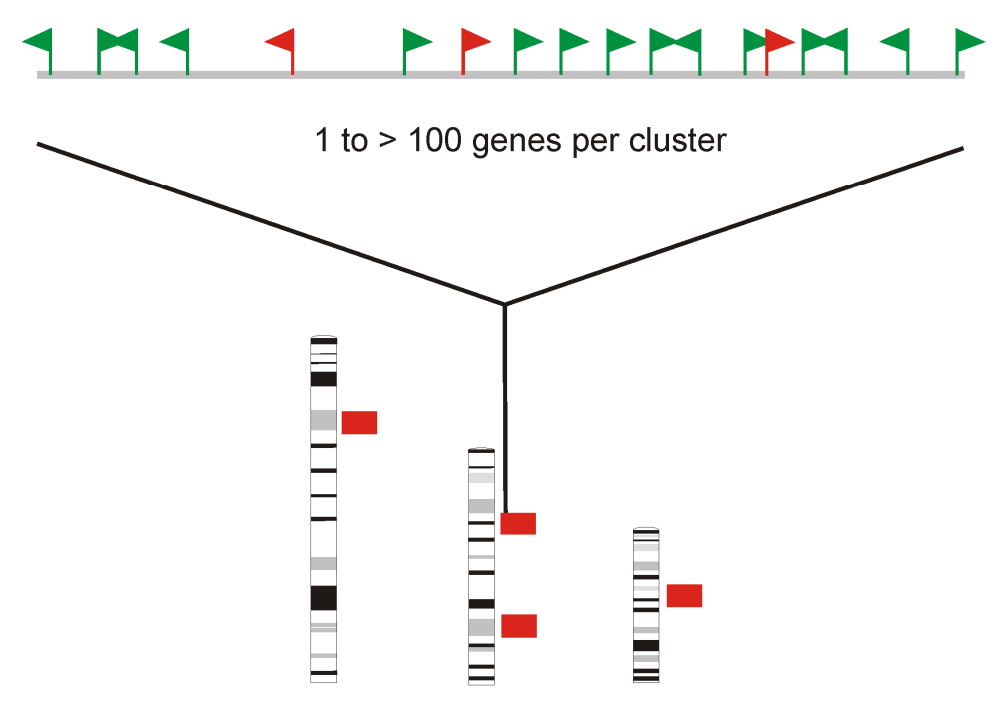

Figure 4: Schematic representation showing genomic organization of olfactory receptor genes. Functional OR genes (green arrows) and pseudogenes (red arrows) are clustered in both transcriptional orientations. Several OR clusters (red squares) can be found on the chromosomes of each species, each containing up to 100 OR genes. Figure modified after Young and Trask, 2002.

\subsubsection{Peripheral odor coding}

A large number of olfactory receptors appears necessary when it comes to encoding the olfactory information from a huge variety of scents. For humans it is estimated that their OR gene repertoire is able to detect from 10000 to over 100000 different volatile compounds (Buck and Axel, 1991; Buck, 2004; Firestein, 2004). But as there are by far more odorant substances than ORs, conclusive theories are needed to explain how odorants are perceived.

Much effort was invested and a theory, which is nowadays the most accepted one, was presented. The theory incorporates that there is exclusively one kind of OR expressed per ORN, which was suggested by in situ and single cell RT-PCR studies (Ressler et al., 1993; Vassar et al., 1993; Malnic et al., 1999; Touhara et al., 1999; Kajiya et al., 2001; Hamana et al., 2003). It further assumes that one type of OR can bind several odor molecules and that one odor molecule can activate multiple ORs. 
Both was demonstrated by heterologous OR gene expression assays (Raming et al., 1993; Kiefer et al., 1996; Krautwurst et al., 1998; Speca et al., 1999; Hatt et al., 2001; Kajiya et al., 2001; Liberles and Buck, 2006). As certain scents vary greatly in their action at different receptors, responsive cells are excited to different degrees. This leads to odorant-specific activation patterns of glomerula in the olfactory bulb (Manzini et al., 2007; Oka et al., 2009; Junek et al., 2010).

In summary the current hypothesis suggest that the olfactory system relies on a combinatorial code where each ORN expresses one OR gene and in which the odor compounds serve as ligands at multiple receptors (Figure 5).

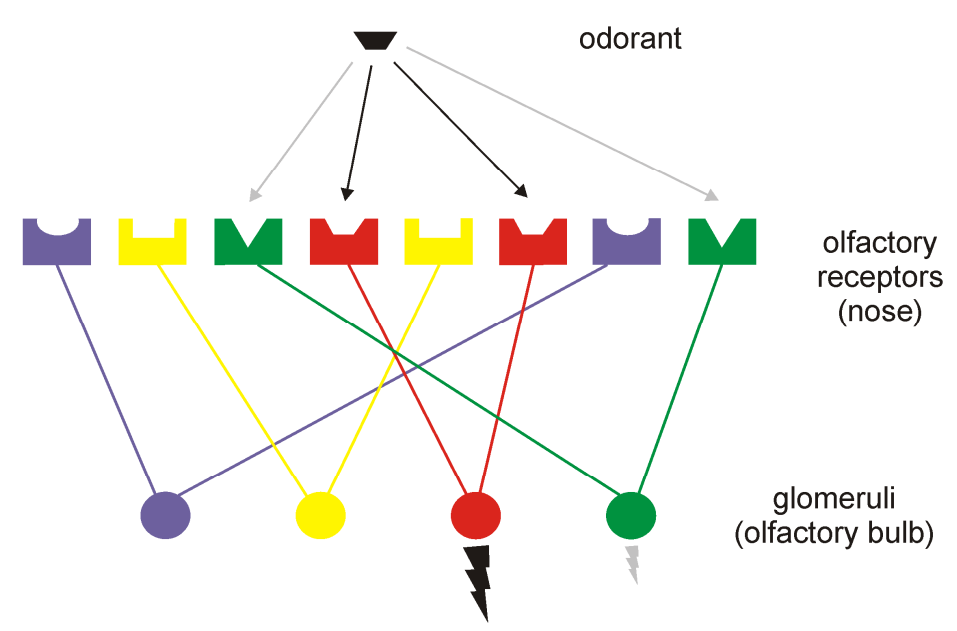

Figure 5: The combinatorial code of olfaction. ORNs expressing a given OR can respond to more than one type of odorant molecule. Each substance may elicit responses at several receptors, perhaps with different response amplitudes. Figure modified after Young and Trask, 2002.

However, recent studies challenge this model, mainly by demonstrating that coexpression of more than one OR per ORN does indeed occur (Rawson et al., 2000; Sato et al., 2007; Tian and Ma, 2008). These findings support a more recent hypothesis which proposes a developmental phase of oligogenic OR expression in ORNs (Mombaerts, 2004). In addition, other studies also suggested a revision of the rather dogmatic view on OR expression. They investigated odorant antagonism and reported that an odor code is not simply a particular combination of activated ORs but is also influenced by antagonistic effects (Spehr et al., 2003; Oka et al., 2004; 
Shirokova et al., 2005). One study even suggested an extended combinatorial receptor code where the possibility of at least some ORNs expressing more than one OR is integrated (Oka et al., 2004). Concluding from these studies it becomes disputable whether the predicted one receptor-one neuron model can still hold true or whether a more complex coding process is at work, i.e. subsets of activated ORs may not only work in parallel but also interact or are co-activated.

Subsequently I want to demonstrate in more detail why the one receptor-one neuron hypothesis became a widely accepted model but also why it is far from being proven.

\subsection{The one receptor-one neuron hypothesis revisited}

"The opposite of a fact is falsehood, but the opposite of one profound truth may very well be another profound truth."

Niels Bohr (1885-1962)

In this chapter evidence supporting the one receptor-one neuron hypothesis is presented and critically examined. In addition, converse studies are shown that produced evidence against this theorie. First, results are analyzed that were obtained from in situ hybridization experiments. Subsequently data from genetic manipulation experiments are shown that investigated axonal projections of ORNs and mechanisms underlying OR expression. The section will close with the presentation of results from single cell RT-PCR approaches and physiological experiments.

\subsubsection{Dual-probe in situ hybridization}

The idea of ORNs expressing only one OR was already established in the early 90ths, when in situ hybridization studies in mouse and rat claimed that the olfactory epithelium is organized in several spatial zones expressing non-overlapping sets of ORs (Figure 6; Ressler et al. 1993; Vassar et al., 1993). Those studies did not find any evidence for ORs being coexpressed in ORNs (Figure 6, B). Furthermore it was demonstrated by in situ hybridization experiments that individual OR gene probes 
hybridize to only about $0.1 \%$ of ORNs (Nef et al., 1992; Stromann et al., 1992), which was, considering a total amount of 1000 ORs, assumed as another indication for the one receptor-one neuron hypothesis (Malnic et al., 1999). In addition, experiments using two-color in situ hybridization for three mouse OR genes (Tsuboi et al., 1999) and dual labeling with genetic markers in gene-targeted mice (Strotmann et al., 2000) also excluded coexpression. A more recent study characterizing expression of several ORs simultaneaously also showed that co-localization of ORs does not occur but that OR expression patterns occupy multiple zones in the OE that overlap with each other (Iwema et al., 2004).

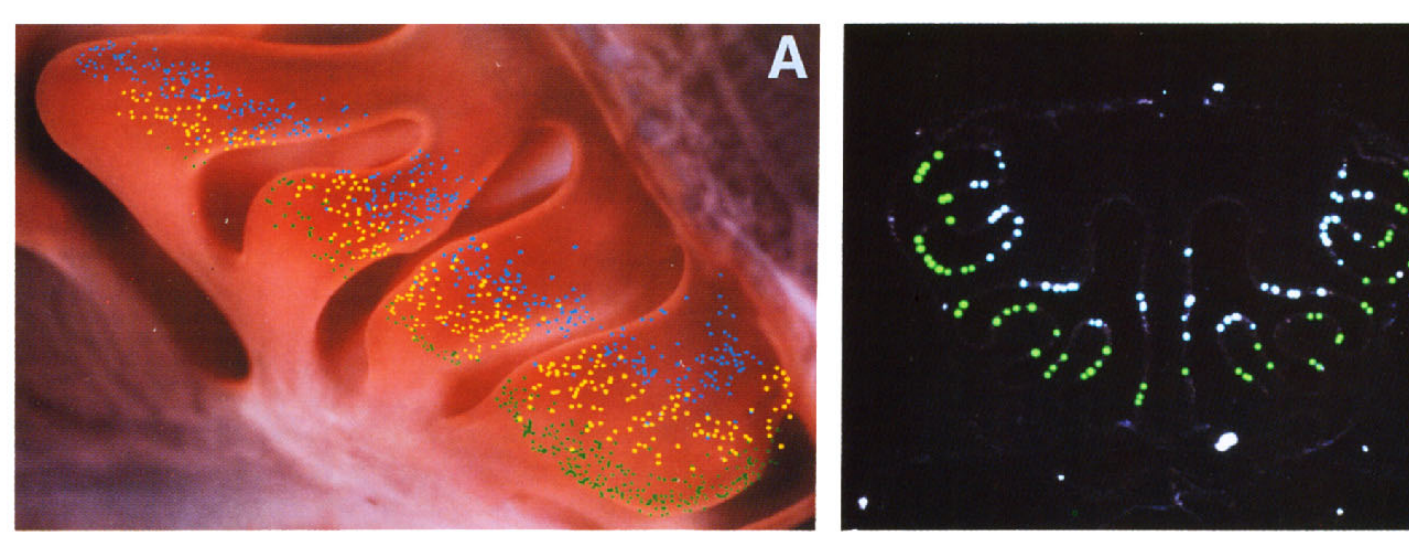

Figure 6: Patterns of olfactory receptor expression in rat. (A) Representation of the turbinate system of the nasal cavitiy illustrating three distinct zones in which three different receptor subfamilies are expressed (green; yellow; blue). (B) Signals in a frontal section of the olfactory tissue showing non-overlapping radial zones of two ORs (green and white). Figure modified after Vassar et al., 1993.

Although those results seem to be convincing at first glance, some of the conclusions drawn from these studies have to be seen critically. The results undeniably did not show co-localization among the tested receptors. But as there are up to 1000 OR genes, there are also 1.000.000 combinations possible, with some dual probes that could produce a different result. So evidence supporting the idea of one ORN expressing just one OR can logically only be drawn from in situ studies as long as no converse results come up.

However, three in situ studies revealed that coexpression of ORs does occur in rodent and zebrafish olfactory tissue (Rawson et al., 2000; Sato et al., 2007; Tian and Ma, 2008). For rat ORNs it was found that two OR genes are often coexpressed 
(Rawson et al., 2000), whereas ORNs in the septal organ of mice were also shown to co-express ORs, but only at a low frequency (Tian and Ma, 2008). In wildtype and transgenic zebrafish, up to $5 \%$ of ORNs that express two given ORs were shown to co-express both receptors (Figure 7; Sato et al., 2007).

However, whether these findings can conclusively disprove the dogma of one neuron possessing only one kind of OR protein remains unclear. One main unresolved caveat is that of all ORs expressed only one may be functional. Despite the intact and full-length open reading frame, the protein may miss certain residues or features that are essential to function in the olfactory signal transduction pathway (Mombaerts, 2004).

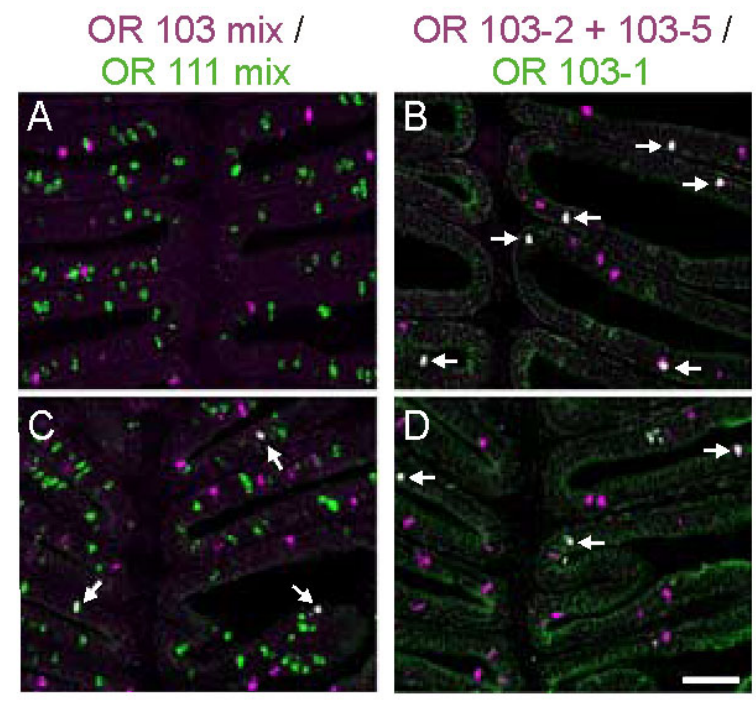

Figure 7: Coexpression of multiple ORs in single ORNs of zebrafish. Double in situ hybridization was perfomed on $\mathrm{OE}$ sections from wild-type and transgenic animals. (A,C) Expression of ORs belonging to the OR103 (magenta) and OR111 (green) subfamilies in a wild-type (A) and a genetically manipulated animal (C). Overlapping signals are only detected for the transgenic line (arrows). (B,D) Coexpression of OR103-1 (green) with OR103-2 and/or OR103-5 (magenta) in both wild-type (B) and transgenic fish (D). Scale bar, $50 \mu \mathrm{m}$. Figure modified after Sato et al., 2007. 


\subsubsection{Axonal convergence}

Further evidence of the stated one receptor-one neuron hypothesis is also produced by studies which investigated axonal projections to glomerula. The differentiation of ORN subtypes according to OR expression was made possible by genetic manipulation (Mombaerts et al., 1996; Feinstein and Mombaerts, 2004; Grosmaitre et al., 2006). It was found that axons of all ORNs that express a given OR coalesce into a single glomerulum per half-bulb, sometimes to a few (Figure 8; Ressler et al., 1994; Vassar et al., 1994; Mombaerts et al., 1996; Vassalli et al., 2002; Feinstein and Mombaerts, 2004). Conversely, electron microscopy revealed that all axons which innvervate a particular glomerulum originate from ORNs that express a given OR (Treloar et al., 2002). Adressing the question of how the axons are directed to their specific glomerula, different approaches were accomplished. First, OR mRNA was detected at a few discrete sites per OB (Vassar et al., 1994; Ressler et al., 1994). Immunostainings with antibodies against specific OR epitopes visualized that OR proteins are also present in the axonal processes and nerve terminals of ORNs (Strotmann et al., 2004). Furthermore, genetic experiments implicated that ORs are critical determinants by which glomerula are formed and innervated (Mombaerts et al., 1996; Mombaerts, 1996; Wang et al., 1998; Treloar et al., 2002; Bozza et al., 2002). However, colocalization of ORs was never observed in these reports. From the studies it was concluded that ORs most likely participate in the targeting of olfactory axons to glomerula and that probably just a single OR is involved in this process.

Although literature makes a strong intuitive and persuasive argument in favor of the one receptor-one neuron hypothesis there is some discrepancy. Regarding the total number of functional OR genes and glomerula in mouse, it becomes obvious that the numbers do not add up. There were 1068 OR genes found (Zhang et al., 2004) but just about 900 glomerula per bulb (Royet et al., 1988; Mori et al., 2006; Wilson and Mainen, 2006), which is $20 \%$ less than expected. However, a new investigation which would confirm the number of glomerula is needed to make a more reliable statement on the observed discrepancy. Eventually this deficit of glomerula may be compensated by axonal coalescence into more than two glomerula, which actually was already shown in early studies (Vassar et al., 1994; Ressler et al., 1994). Another objection on previous conclusions deals with the following thoughts. If two or even more OR genes were consistently coexpressed in one kind of ORNs, only one OR could be used for axon targeting into glomerula. In contrast, axonal projections into just two glomerula per bulb should not be excluded automatically if ORNs were 
expressing few ORs simultaneously. Unfortunately these ideas were not followed up yet as there were not enough double labeling experiments done to either exlude or validate these theories (Mombaerts, 2004).

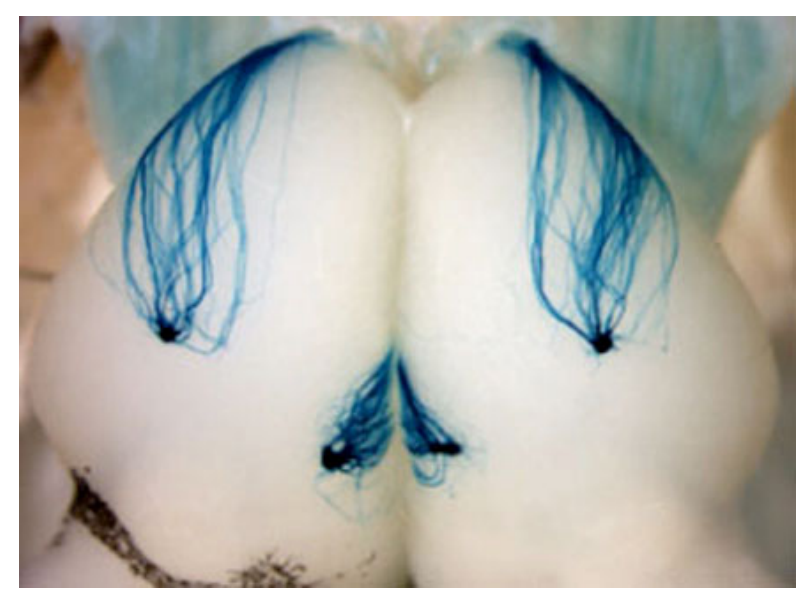

Figure 8: Bulbar patterns of olfactory receptor expression in rat. Dorsal view on both OBs. Each of the two bulbs is internally symmetrical, with glomeruli for a particular OR typically residing in both halves of the bulb. The image shows four genetically labeled glomeruli of a M72-IRES-taulacZ-mouse. Axons of all ORNs that express the mouse OR M72 coalesce into the depicted glomeruli. Figure taken from Max-Planck-Institute for Biophysics/Mombaerts (unpublished).

http://www.mpg.de/bilderBerichteDokumente/dokumentation/jahrbuch/2009/biophysik/forschungsSchwerpunkt/index.html

\subsubsection{Monoallelic expression of ORs}

A typical gene is normally expressed biallelically. Surprisingly several studies found that OR genes are subject to random monoallelic expression (Chess et al., 1994; Mombaerts et al., 1996; Serizawa et al., 2000; Ishii et al., 2001; Li et al., 2004; Gimelbrant et al., 2007). Different techniques were thereby employed which involved single-cell reverse transcription polymerase chain reaction (RT-PCR; Chess et al., 1994), genetic manipulations (Mombaerts et al., 1996) and dual genetic marker analysis (Strotmann et al., 2000). One quite conclusive study demonstrated the exquisite fidelity of monoallelic expression by a combined RNA/DNA in situ hybridization (Ishii et al., 2001). The authors showed that a single RNA signal corresponds to just one of the two DNA signals in a single cell. But what happened to 
the silenced allel? An irreversible silencing of the corresponding OR allel was demonstrated to be unlikely since both alleles can be expressed if one allele fails to produce a functional OR protein (Serizawa et al., 2003; Feinstein et al., 2004; Lewcock and Reed, 2004; Shykind et al., 2004).

However, one interesting question arises now from these results. Does monoallelic expression imply monogenic expression as well? If an OR choice mechanism treated both allelels independently from each other, monoallelic and monogenic expression would be directly linked (Fuss and Ray, 2009). But as long as no proposed mechanism is experimentally shown and as long as studies show coexpression of ORs in single ORNs (see 1.4.1) the findings of monoallelic expression should not necessarily imply a monogenic expression of OR genes.

\subsubsection{Positive and Negative feedback regulation of OR gene expression}

If a choice-mechanism led to the selection of only one particular OR, a subsequent signaling pathway would have to be implemented to stabilize this choice and prevent random switching of OR expression. It has been proposed that negative feedback signals prevent continuation of OR gene choice once a functional OR protein is made (Serizawa et al., 2003; Lewcock and Reed, 2004; Shykind et al., 2004). The feedback signals are suggested to target regulatory elements that control expression of ORs, namely factors at the locus control region (LCR). LCRs are DNA elements which promote the binding of a protein activation complex that is able to activate and enhance the expression of genes to which they are linked to. With regard to OR gene expression, it was shown that a few kb-long region far upstream of a gene cluster is positively regulating gene expression (Nagawa et al., 2002; Serizawa et al., 2003). Once the activation complex has initiated the expression of a particular OR gene, the functional OR protein is suggested to inhibit further activation of additional OR genes (Figure 9; Serizawa et al., 2003; Serizawa et al., 2004; Lewcock and Reed, 2004; Shykind et al., 2004; Nguyen et al., 2007; Fleischmann et al., 2008).

However, an irreversible silencing process does not seem probable as it was found in immature ORNs that switching of ORs can occur (Shykind et al., 2004). Therefore, conclusions aiming on only one kind of OR being expressed in ORNs should be treated with caution, especially as some studies can not test on multiple OR transcripts simultaneously. 


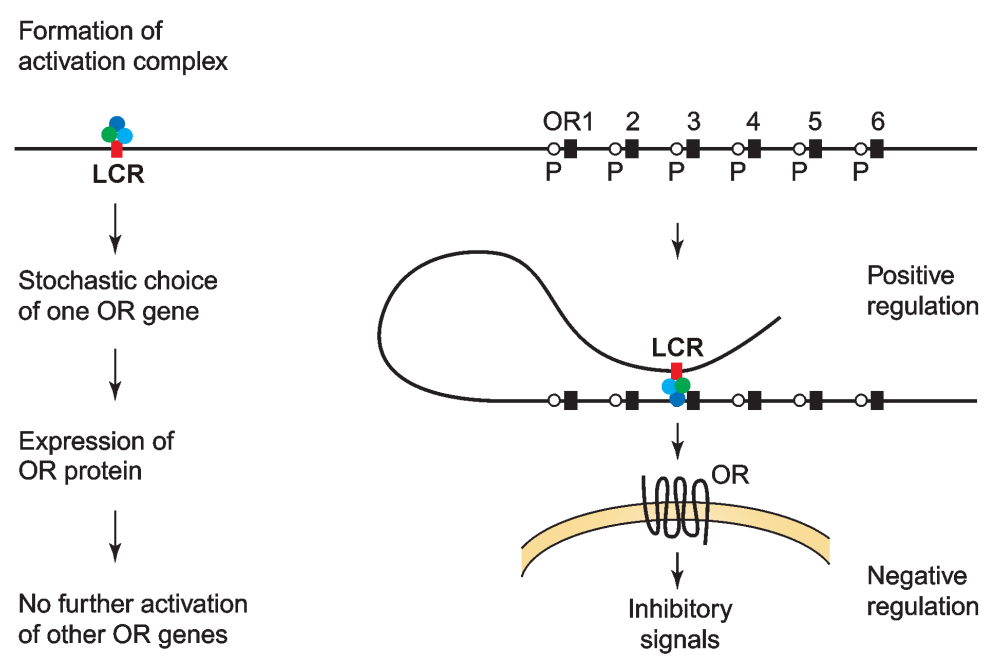

Figure 9: A model for OR gene expression. An activation clomplex bound to a locus control region (LCR, red rectangle) stochastically chooses one promoter site and thereby activates the expression of one particular OR gene. Once the functional OR molecule has been synthesized it transmits inhibitory signals to block further activation of additional OR genes. Figure modified after Serizawa et al., 2004.

\subsubsection{Single cell RT-PCR}

In order to test multiple OR expression directly, sets of expressed ORs can be simultaneously examined in single ORNs using single cell reverse transcription-PCR (RT-PCR. Although the huge OR repertoire poses technical obstacles, a few studies managed to obtain results from single cells, some even in conjunction with calcium imaging of the responses to applied odorants (Malnic et al., 1999; Touhara et al., 1999; Kajiya et al., 2001; Hamana et al., 2003). To date all of these studies reported that among the tested ORs no colocalization was observed. These findings were interpreted as a proof of the assumption that single ORNs exclusively express one OR gene.

Striking arguments will thus illustrate the limitations of such conclusions. First, in up to $70 \%$ of all single cells no OR gene was able to be amplified. On the one hand this most probably comes from the small selection of PCR primers of the huge OR 
superfamily. On the other hand it may come from the technical difficulty of isolating sufficient amounts of mRNA from just a single cell. Second, even when RT-PCR was successful, the minute amounts of mRNA could result in a non-representative amplification of just one OR mRNA species and the primer bias may leave certain OR genes undetectable (Mombaerts, 2004).

However, if not few but just one kind of OR was found in RT-PCR studies, the receptors response pattern would still have to be verified to be the same as the one of the observed and harvested ORN. Therefore the OR would have to be expressed heterologously in order to corroborate whether this isolated receptor is indeed the (only) one being responsible for the observed sensitivity pattern to certain odorants. Although some studies succeeded to express ORs in a heterlogous system (Krautwurst et al., 1998; Speca et al., 1999; Kajiya et al., 2001; Liberles and Buck, 2006), the technique is not appropriate for ORs (McClintock and Sammeta, 2003). It needs quite some expertise to be handled as several co-factors are required for proper translocation and functioning of the receptors (Katada et al., 2004, Saito et al., 2004; Von Dannecker et al., 2006). Maybe the adenovirus-mediated gene transfer of ORs will turn out to be a more successful technique in the future (Zhao et al., 1998; Touhara et al., 1999; Ivic et al., 2000; Touhara, 2001).

Nonetheless, concluding from the technique itself, single cell RT-PCR has a big advantage compared to other methods. If some ORNs indeed express multiple OR genes simultaneously, even small amounts of mRNA will be detected by appropriate amplification protocols. Anyhow, the question whether multiple expressed ORs are also functional will remain unsolved using this technique.

\subsubsection{Physiological data}

All the reports and results that were presented so far did not contain physiological data. However, results from physiological experiments may potentially show that multiple expressed ORs are indeed functional and that they encode odorant information.

It was shown for a variety of vertebrate species that individual receptor cells can be activated by odorants which greatly differ in structural or perceptual qualities (Revial et al., 1982; Firestein et al., 1993). Using functional $\mathrm{Ca}^{2+}$-imaging, it was observed that responses to diverse odorant mixtures were differentially affected by pharmacological agents (Restrepo et al., 1993; Tareilus et al., 1995; Rawson et al., 
1997). In addition, patch clamp measurements recorded either depolarizing or hyperpolarizing cellular responses upon application of certain odorants (Boekhoff et al., 1994; Morales et al., 1994). These results may support the idea of a multiple mediation of olfactory transduction within the same cell, depending on the odorant molecule. But then the question arises how different transduction pathways can be activated if it is assumed that there is just one kind of OR present. The most parsimonious explanation for these observations is that multiple ORs are present and that they are linked to different transduction pathways (Rawson et al., 2000).

A model which also predicts a coexistence of several transduction mechanisms in single ORNs was recently presented (Oka et al., 2004). The authors evaluated an older study where many instances of suppression or synergism in the perception of odor mixtures were observed (Laing et al., 1989). According to the findings that cellular responses to mixtures of odorant compounds are often greater or less than the additive sum of the responses to the individual substances, the authors reasoned that ORs, like other GPCRs, are susceptible to antagonism. They further demonstrated the proposed antagonism between odorants by calcium-imaging experiments and developed a concept of antagonism-based modulation of receptor codes for odorants (Oka et al., 2004). This new model suggests an extended combinatorial receptor code in which the possibility of at least some ORNs expressing more than one OR is integrated.

Further indications pointing towards a scheme where at least some individual ORNs express multiple types of ORs came from calcium-imaging experiments in our lab. One work evaluated the activation pattern of ORNs applying 19 single amino acids. Thereby a huge number of response patterns was observed (Manzini and Schild, 2004; Schild and Manzini, 2004). A recent study characterizing aminergic stimuli also found a great number of different response profiles (Gliem et al., 2009). To explain the diversity of the observed response patterns two options are now conceivable. It is either feasible that a large repertoire of amino acid- and amine-binding ORs exist in the Xenopus genome or that at least some ORNs express more than one OR gene simultaneously.

Another striking study supporting the latter assumption showed results of crossadaptation experiments of individual cells to three highly effective amino acids, arginine, methionine and lysine (Gutermann, 2006). The experimental calciumimaging protocol was as follows: At first, ORN responses were recorded upon application of the three single amino acids. Subsequently bath solution was replaced by a solution, containing a high lysine concentration in order to saturate all lysine- 
sensitive receptors. If lysine-responsive ORNs expressed just one kind of OR gene, no odorant stimuli would then be able to trigger further responses in those cells. But surprisingly it turned out that this was not the case (Figure 10). For some cells it was shown that they still respond to at least either arginine or methionine, but not to lysine. This kind of study is worth being emphasized because it may demonstrate that multiple ORs are expressed in at least some ORNs and that they are indeed functional.

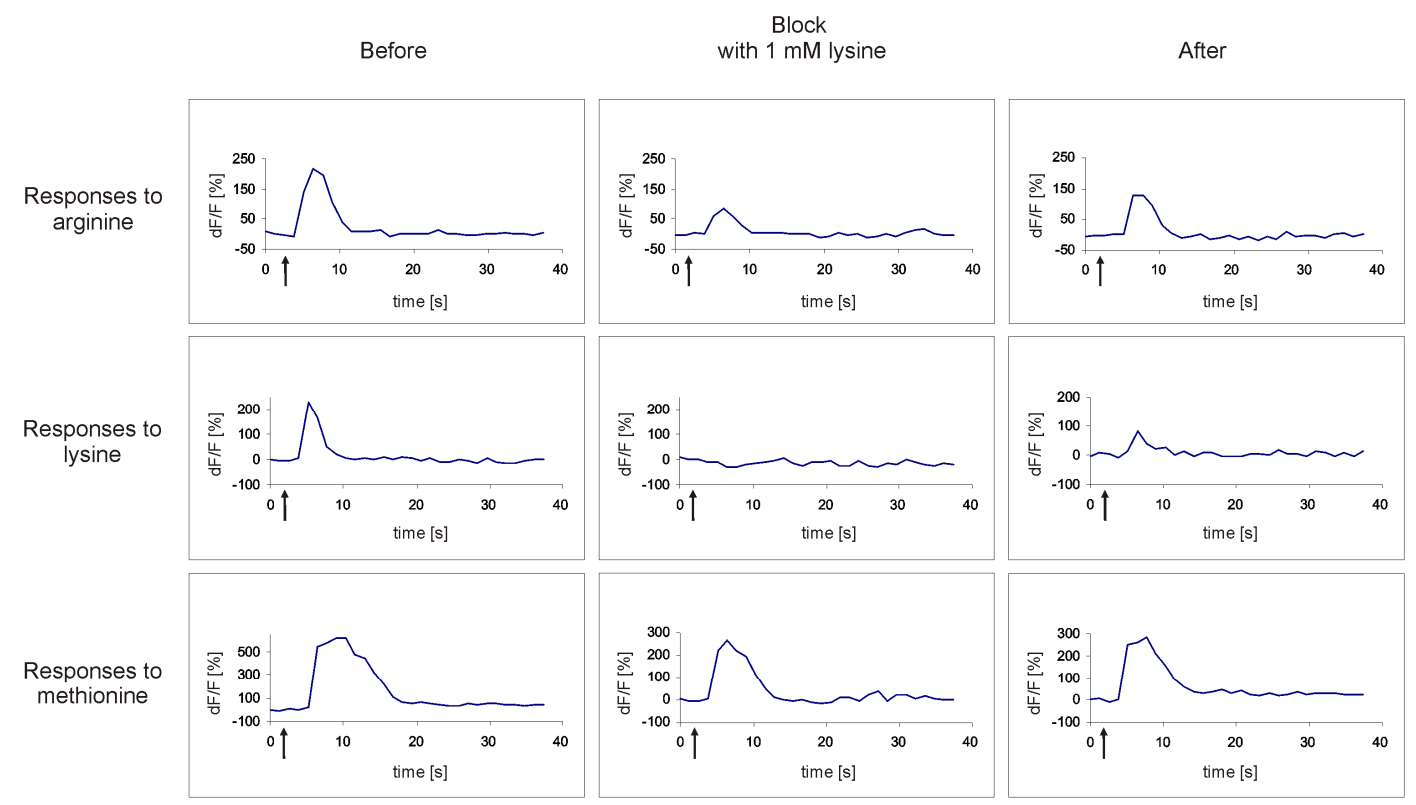

Figure 10: Crossadaptation of amino acid-sensitive ORNs. The diagram shows the intracellular $\mathrm{Ca}^{2+}$ transients for one individual ORN that was stimulated with arginine, lysine and methionine. The onset of stimulus application is indicated by an arrow. Responses are shown before, during and after the lysine-blockage. Figure modified after Gutermann, 2006. 


\subsection{Goal of the thesis}

In the introduction I demonstrated that olfactory receptors (ORs) are essential elements for odorant detection. They play a fundamental role in terms of encoding olfactory information. As certain odorants have different binding affinities at ORs, olfactory neurons become excited differently by certain stimuli. The differential response patterns subsequently determine odor-specific activity patterns in the olfactory bulb.

In order to explain peripheral odor coding, a widely accepted hypothesis assumes that each ORN expresses only one OR gene and that odor detection relies on a combinatorial coding scheme. However, with regard to the assumption of just one receptor gene being expressed, this theory is far from being proven, as I outlined above. The main point of criticism aims on the fact, that past studies did not satisfactorily prove that single ORNs do not express all other possible ORs except the one which was detected. Supporting a recent hypothesis of a developmental phase of oligogenic OR expression, few studies showed either directly or indirectly that subsets of single ORNs exist, which express more than one OR simultaneously.

Consequently, these findings motivated to examine OR gene expression and investigate which hypothesis can be approved. The purpose of this study was thereby to analyze how many chemoreceptor genes, namely olfactory and vomeronasal type 1 receptors, are simultaneously expressed in ORNs of larval Xenopus laevis. The following questions were addressed:

1. Which olfactory and vomeronasal receptors are expressed in the olfactory tissue at the investigated larval stages?

2. Do olfactory receptor neurons of larval Xenopus laevis express multiple receptors simultaneously?

3. Is one of the found receptors sensitive to certain applied ligands?

In order to answer the questions I developed a single cell RT-PCR approach, which I later combined with functional $\mathrm{Ca}^{2+}$ imaging. 


\section{2}

\section{MATERIALS AND METHODS}

\subsection{The experimental animal}

\subsubsection{Xenopus laevis}

The South African clawed frog, Xenopus laevis, is an amphibian which belongs to the family of Pipidae and to the order of Anura. The name is derived from the animal's three short claws on each hind foot. Members of the Pipidae family are toothless as well as tongueless and use their hands to push food in their mouths and down their throats. They are completely aquatic. Although they lack true ears they have a lateral line system by which the animals are able to sense vibrations in the water. For food detecton the animal relies on its sensitive fingers, the lateral line system but mostly on its sense of smell (Avila and Frye, 1978; Nieuwkoop and Faber, 1994). Adult animals of the Pipidae family are scavengers and will eat living, dying, dead or any pieces of biowaste. In contrast, animals of larval stages will consume food in form of small organic particles, such as algae.

The natural habitat of Xenopus laevis is south of the Sahara Desert along the western boundary of the Great African Rifts. The animal lives at the bottom of warm and stagnant water and is native to wetlands, ponds and lakes. As it is an invasive species and is moreover tremendously used as an experimental animal in scientific research and for education purposes, the animal now occupies several areas all over the world. Because of its genetic simplicity, Xenopus laevis, a tetraploid animal, is desired as a genetic model. Moreover it is an important model organism in developmental biology. Oocytes of this animal provide an excellent expression system in the field of molecular biology. The expression of membrane channels makes this system quite a powerful tool in electrophysiology.

Furthermore, Xenopus laevis, especially at its larval stages, is an excellent model system to study the olfactory system and offers several benefits. As the animal is poikilothermal all experiments can be done at room temperature. For olfactory 
research further advantages are that tadpoles do not have a lamina cribosa or any bony structure, which is in contact to compontents of the olfactory system. Therefore any kind of slice preparations can be carried out without particular difficulties or obstacles (see Figures 12, 13).

Adult frogs were purchased from commercial suppliers (Kaehler, Hamburg, Germany; Nasco, USA) and held in aquaria (water temperature $20^{\circ} \mathrm{C}$ ). The animals were fed with pondstick food (Tetra Pond, Melle, Germany). To initialize breeding, frogs were first separated by sex. Human chorionic gonadotropin (Sigma, Deisenhofen, Germany) was then repeatedly injected subcutaneously into the dorsal lymph sac. Subsequently, breeding pairs were housed together overnight, and the next day the embryos were collected and kept in separate aquaria (water temperature $20^{\circ} \mathrm{C}$ ). The tadpoles were fed with algae (Dose Aquaristik, Bonn, Germany). For all experiments tadpoles of developmental stages 52-54 (Figure 11; Nieuwkoop and Faber, 1994) were used. These stages were reached after approximately three weeks.

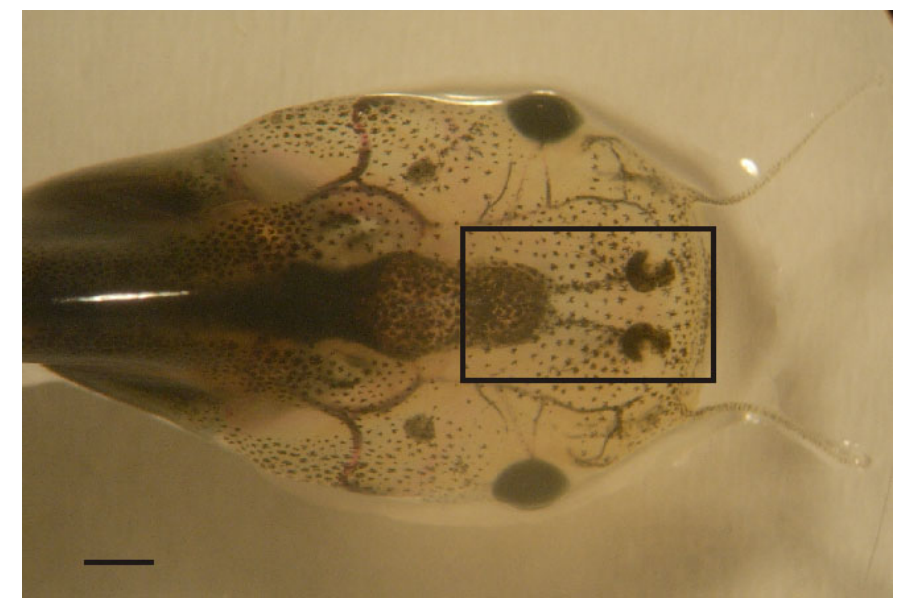

Figure 11: Xenopus laevis tadpole (stage 52). The olfactory system is marked by a black rectangle. It indicates the block of tissue that was used for the experiments.

Scale bar, 1 mm. Figure modified after Gliem et al., (2009). 


\subsubsection{Organisation and development of the olfactory system in Xenopus laevis}

\section{The olfactory epithelium}

The olfactory epithelia of Xenopus laevis originate from two olfactory placodes that become visible at stage 23 (Klein and Graziadei, 1983). The first axons reach the olfactory bulb at stage 30 and start to form synapses with mitral cells at stage 37-38 (Byrd and Burd, 1991). Anyhow, it was not yet possible to stain mature ORNs prior to stage 45 (Hansen et al., 1998). Expression of the first ORs is detectable from stage 32 onwards (Mezler et al., 1999). Around stage 40 the placodes start to segregate into the principal cavity and vomeronasal organ. It is assumed that around stage 47 the aquatic olfactory system is fully functional (Gaudin and Gascuel, 2005). Further segregation of the olfactory epithelium occurs from stage 51 until the end of metamorphosis, when the lateral cavitiy starts to form and expand. Simultaneously a remodeling of the larval principal cavity into the principal cavity of the adult animal is observed (Nieuwkoop and Faber, 1994; Hansen et al., 1998). In total, the nose of the adult frog is basically composed of three olfactory subsystems which are localized in three chambers (Altner, 1962; Hansen et al., 1998). They are interconnected and contain different epithelia for the detection of different odorant classes. The major chamber is called principal cavity or 'air-nose'. It is permanently filled with air and closed under water. In contrast the other two chambers, which are the lateral olfactory cavity ('water-nose') and the vomeronasal organ, are permanently filled with water. The detection of air-borne as well as water-borne odorants is therefore accomplished by the epithelia of the principal cavity and lateral cavity respectively (Freitag et al., 1998) whereas pheromone detection occurs in the vomeronasal organ (Halpern, 1987).

For stimuli detection it is known that ORNs of the water- and air-nose are endowed with class I and class II ORs respectively (Freitag et al., 1995) but also express vomeronasal receptors type 1 (V1Rs; Date-Ito et al., 2008). Class I receptors are also referred to as fish-like receptors and class II ones as mammalian-like receptors. For receptor neurons of the vomeronasal organ it was found that they predominately express genes of the Xenopus V2R receptor family (Hagino-Yamagishi et al., 2004). Regarding the distribution of ORs it was shown that from stage 49 to at least stage 55 receptors of class I and II are both expressed in cells of the principal cavity. However, after metamorphosis only class II receptors are detectable in the airfilled chamber of the adult frog whereas the lateral cavity only expresses class I receptors (Freitag et al., 1995). 
All three epithelia (principal and lateral cavity, vomeronasal organ) contain ORNs, sustentacular cells and basal cells. Xenopus laevis possesses two types of ORNs bearing either cilia or microvilli and two types of sustentacular cells, which are either secretory or ciliated (Hansen et al., 1998). The structure of the Xenopus OE (Figure 12 ) is basically organized as described in section 1.2.1. . ORNs lie in the middle layer of the epithelium and extend their dendrites to the apical surface with their cilia or microvilli lying in a mucus coat (Figure 12, D). However, sustentacular cells form a tightly packed columnar monolayer on the apical surface and extend their processes across the entire epithelium. At level of the basal lamina, these processes terminate in endfeet-like structures (Figure 12, E) that lie in immediate vicinity of the basal cells.

\section{The olfactory bulb}

As briefly mentioned above, the differentiation of the main OB starts once the first synapses were created between ORN axons and dendrites of mitral cells (stage 30). All layers of the $\mathrm{OB}$ which comprise the olfactory nerve layer, glomerular layer, mitral cell layer and granule cell layer, are observable from stage 44 and become indistinguishable from the adult pattern by stage 48 (Byrd and Burd, 1991). The basic structure of the $\mathrm{OB}$ can be subdived into the main $\mathrm{OB}$, the accessory $\mathrm{OB}$ and the mitral and granule cell layers (Figure 13). The main OB consists of the olfactory nerve and the glomerular layers. The glomerular layer contains about 350 glomerula (stages 51-56; Nezlin and Schild, 2000). These are aggregated spherical structures formed by ORN axon terminals and mitral cell neuropils. Within the glomerular layer periglomerular cells are found that exhibit extensive dendritic arborizations (Nezlin and Schild, 2005). Posterior of this layer the somata of the mitral cells are found which appear to be scattered between the glomerular and granule cell layers. The granule cells themselves form a compact group of cells near the parventricular ependyma (Byrd and Burd, 1991). Regarding neurotransmission ORN axons and mitral cells were identified as glutamatergic whereas periglomerular and granule cells were shown to be GABAergic (Nezlin and Schild, 2000). Laterally of the main olfactory bulb, the accessory olfactory bulb resides. It receives axonal inputs from vomeronasal receptor neurons of the vomeronasal organ. Thereby the axonal fibers run laterally in the olfactory nerve. Like the main olfactory bulb, the axonal inputs form synapses with mitral cells within spherical glomerular structures. 

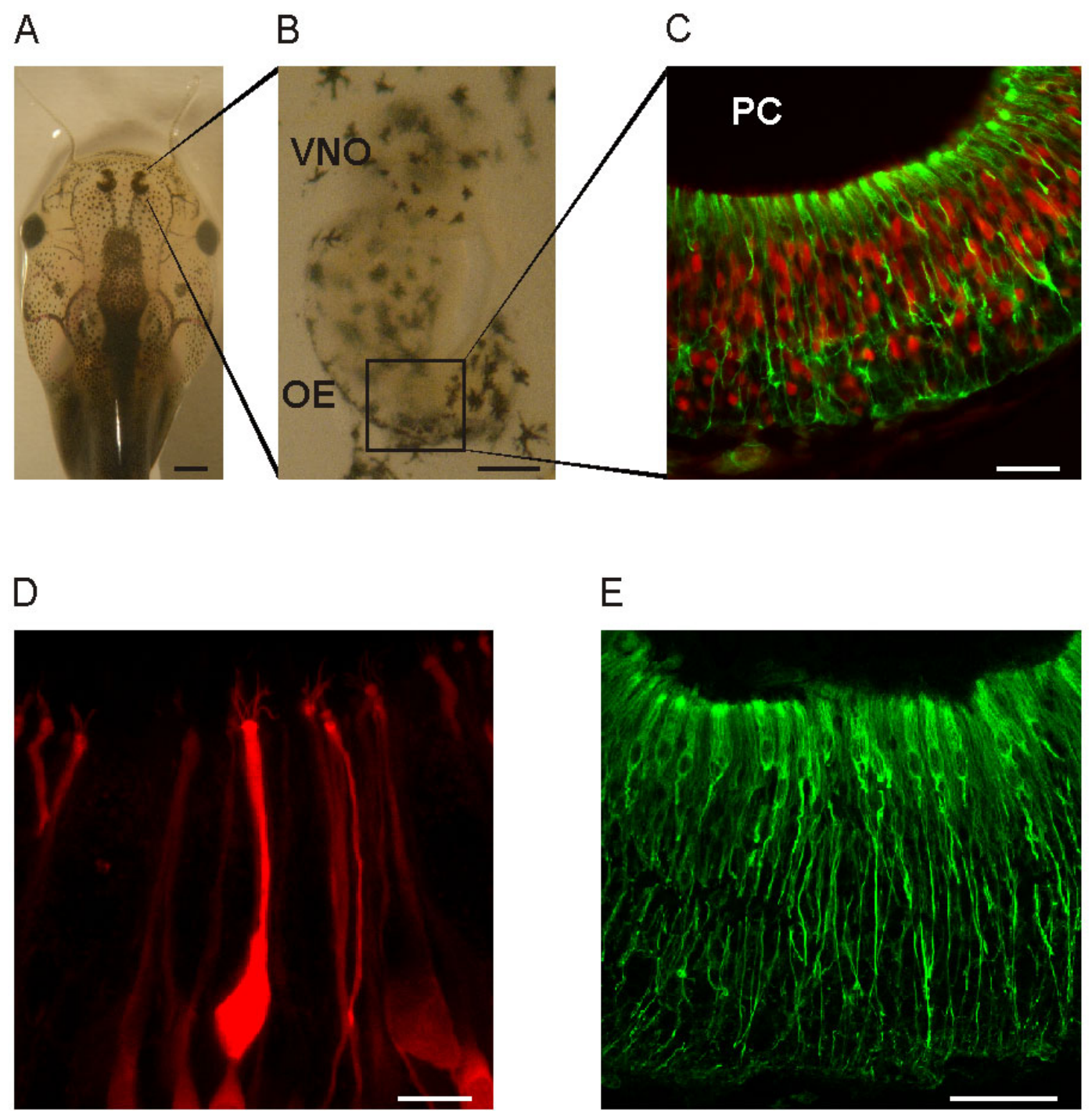

$\mathrm{E}$

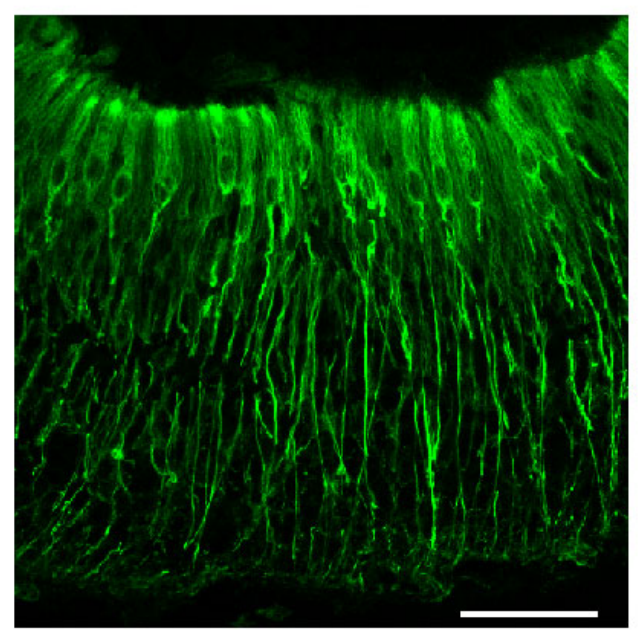

Figure 12: Immunohistochemical staining of the OE of Xenopus laevis larvae.

(A,B) Acute slice preparation of the olfactory epithelium of larval Xenopus laevis. (C) Olfactory receptor neurons in a slice of the OE were stained with a biocytin-streptavidin backtrace (red). Sustentacular cells are visualized by a cytokeratin type II immunostaining (green). (D) Olfactory receptor neurons extend a long dendrite to the principal cavity and end in a knob bearing cilia or microvilli. (E) Sustentacular cells form a tightly packed columnar monolayer on the apical side of the $\mathrm{OE}$ and extend their processes across the complete width of the OE. Scale bars: $1 \mathrm{~mm}$ (A); $200 \mu \mathrm{m}$ (B); $50 \mu \mathrm{m}(\mathrm{C}+\mathrm{E}) ; 10 \mu \mathrm{m}$ (D). Abbreviations: VNO, vomeronasal organ; OE, olfactory epithelium; PC, principal cavity. Figure modified after Gliem et al. (2009). 


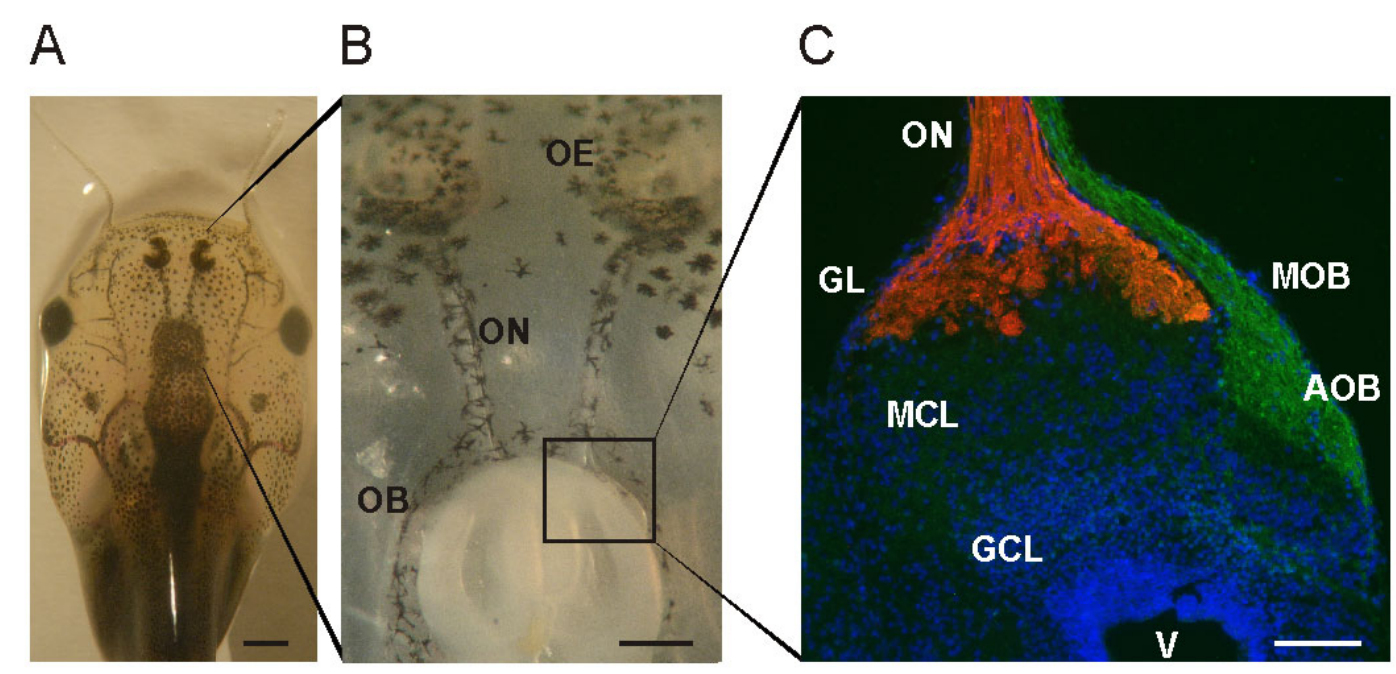

Figure 13: Immunohistochemical staining of the OB of Xenopus laevis larvae.

$(\mathrm{A}, \mathrm{B})$ Typical nose-brain preparation with two intact olfactory epithelia of larval Xenopus laevis. (C) The constitution of the olfactory bulb is shown by a triple labeling. Thereby incoming axons of ORNs (red) were labeled by biocytin electroporation in the principal cavity. Contrary, axonal fibers from the vomeronasal organ were stained with an antibody against calretinin (green). Nuclei of the OB were stained with DAPI (blue).

Scale bars: $1 \mathrm{~mm}(\mathrm{~A}) ; 500 \mu \mathrm{m}$ (B); $100 \mu \mathrm{m}$ (C). Abbreviations: OE, olfactory epithelium; ON, olfactory nerve; OB, olfactory bulb; GL, glomerular layer; MCL, mitral cell layer; GCL, granule cell layer; MOB, main olfactory bulb; AOB, accessory olfactory bulb.

Figure modified after Gliem et al. (2009). 


\subsection{Tissue preparations of the olfactory epithelium}

For slice preparation, tadpoles of Xenopus laevis were anesthetized in a mixture of ice and water and then killed by transaction of the brain at its transition to the spinal cord. All procedures for animal handling and tissue dissections were carried out according to the guidelines of the Göttingen University Committee for Ehics in Animal Experimentation. A block of tissue containing the olfactory epithelia, the olfactory nerves and the brain was cut out (see Figure 11) and kept in bath solution (see section 2.5.1). For the preparation of slices of the OE the tissue was glued onto the stage of a vibroslicer (VT 1200S; Leica Microsystems GmbH, Wetzlar, Germany) and cut horizontally into 140 to $150 \mu \mathrm{m}$ thick slices. The slices of the OE preparation were then transferred to a recording chamber which contained $200 \mu$ l of bath solution. For imaging soma $\left[\mathrm{Ca}^{2+}\right]_{\mathrm{i}}$ the bath solution additionally contained $50 \mu \mathrm{M}$ Fluo-4/AM (Molecular Probes, Leiden, The Netherlands). Thereby Fluo-4/AM was dissolved in DMSO (Sigma, Deisenhofen, Germany) and Pluronic F-127 (Molecular Probes). The final concentrations of DMSO and Pluronic F-127 did not exceed $0.5 \%$ and $0.1 \%$ respectively. ORNs of larval Xenopus laevis express multidrug resistance transporters with a wide substrate spectrum which also includes $\mathrm{Ca}^{2+}$-indicator dyes (Manzini and Schild, 2003b; Manzini et al., 2008). To avoid transporter-mediated destaining of the OE slices $50 \mu \mathrm{M}$ MK571 (Alexis Biochemicals, Grünberg, Göttingen Germany), an inhibitor of multidrug transporters, was added to the incubation solution. The tissue slices were then incubated on a shaker at room termperature for $35 \mathrm{~min}$.

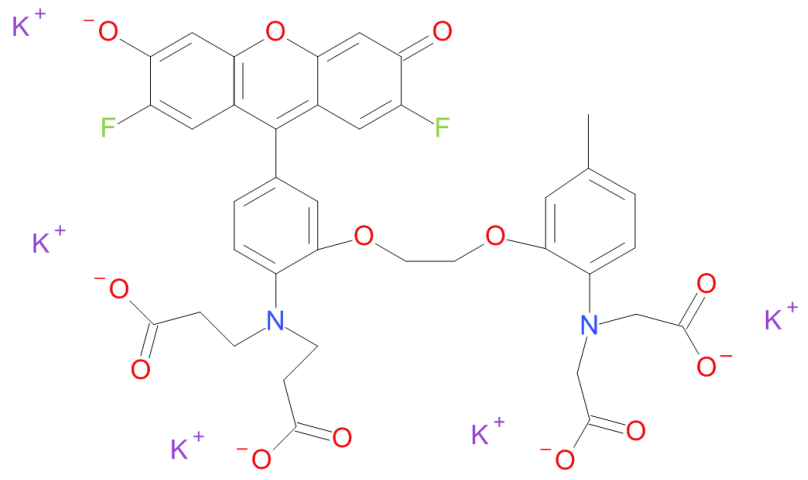

Figure 14: Chemical structure of Fluo-4/AM. 


\subsection{Physiological experiments}

Single ORNs that were supposed to be investigated for OR expression were either identified using patch-clamp or calcium-imaging. After a cell was selected it was collected from the olfactory epithelium. Thereby the single cell was accurately sucked into a patch pipette while simultaneously detaching it from neighbouring cells.

\subsubsection{Patch-clamp recordings}

For patch-clamp measurements the slices were fixed with a grid in the recording chamber and viewed through a 40x water immersion objective mounted to an Axioskop 2 microscope equipped with Nomarski optics (Zeiss, Göttingen, Germany). Olfactory receptor neurons could be easily recognized by their characteristic shape. Patch electrodes with a tip diameter of 1-2 $\mu \mathrm{m}$ and a tip resistance of approximately 7-11 $\mathrm{M} \Omega$ were pulled from borosilicate glass capillaries with $1.8 \mathrm{~mm}$ outer diameter (Hilgenberg, Malsfeld, Germany) using a two-stage pipette puller (PC-10, Narishige, Japan). The pipettes were then filled with $4 \mu \mathrm{l}$ of an internal solution (see section 2.5.1). Voltage pulses were delivered from a microcontroller (Schild et al., 1996) to a $\mathrm{D} / \mathrm{A}$ converter and then to the patch-clamp amplifier (EPC7, List, Darmstadt, Germany) in order to assess the impedance in the on-cell and whole-cell configurations. The holding potential in the on-cell configuration was set to $0 \mathrm{mV}$ whereas in the whole-cell configuration it was adjusted to $-80 \mathrm{mV}$. To verify whether a patch-clamped cell was indeed a receptor neuron and no sustentacular cell, membrane currents were recorded once a gigaseal had formed. Olfactory receptor neurons showed spontaneous spiking activity in the on-cell mode and typical voltagegated sodium and potassium currents in the whole cell configuration. Sustentacular cells showed no electric activity. Evaluation of the current traces was performed using Matlab (MathWorks, Natick, USA). After having established the whole-cell configuration by applying negative pressure to the pipette (Hamill et al., 1981), cytoplasm was allowed to diffuse into the pipette for about $1 \mathrm{~min}$ prior to cell harvesting. 


\subsubsection{Calcium-imaging in tissue slices}

In order to detect odorant-induced responses of ORNs, calcium imaging was perfomed prior to cell harvesting. Intracellular calcium concentrations were monitored using a custom-built upright confocal line scanning illumination microscope described by Junek et al. (2009). Fluorescence images (excitation at $488 \mathrm{~nm}$, emission 497-567 nm) of the olfactory epithelium were acquired at about $1 \mathrm{~Hz}$ per image with about 10 images taken as control images before the onset of stimulus delivery. Before starting the calcium imaging experiments, the slices were rinsed with bath solution for at least 5 min. Image analysis was performed using custom programs written in Matlab. Thereby fluorescence changes $\Delta \mathrm{F} / \mathrm{F}$ of Fluo- 4 were calculated for individual ORNs as $\Delta \mathrm{F} / \mathrm{F}=\left(\mathrm{F}_{1}-\mathrm{F}_{2}\right) / \mathrm{F}_{2}$, where $\mathrm{F}_{1}$ was the fluorescence averaged over the pixels of a cell, while $\mathrm{F}_{2}$ was the average fluorescence of the same pixels prior to stimulus application, averaged over five images. A response was assumed if the following two criteria were met: (i) the first two fluorescence intensity values after stimulus arrival at the $\mathrm{OE}, \Delta \mathrm{F} / \mathrm{F}\left(\mathrm{t}_{1}\right)$ and $\Delta \mathrm{F} / \mathrm{F}\left(\mathrm{t}_{2}\right)$, had to be larger than the maximum of the prestimulus intensities; and (ii) $\Delta \mathrm{F} / \mathrm{F}\left(\mathrm{t}_{2}\right)>\Delta \mathrm{F} / \mathrm{F}\left(\mathrm{t}_{1}\right)$ with $\mathrm{t}_{2}>\mathrm{t}_{1}$.

\subsection{Molecular biology experiments}

ORNs of Xenopus express olfactory and vomeronasal receptors (Freitag et al., 1995; Mezler et al., 1999; Date-Ito et al., 2008). Therefore molecular biology experiments aimed to detect expression of these kinds of chemoreceptors in ORNs of the investigated larval stages.

\subsubsection{RT-PCR and primer design}

\section{$R T-P C R$}

Genes of ORs and V1Rs are intronless genomic structures and therefore consist of only one exon. Accordingly, no intro-spanning primers can be designed for PCR. This knowledge is of crucial importance when it comes to reverse transcription PCR (RTPCR) investigating expression of these receptors. If genomic DNA (gDNA) material is not eliminated prior to a direct PCR, the amplification protocol will often incorporate 
a small but not unimportant risk of creating contaminating PCR products. These are derived from any residual gDNA, which can, as cDNA, serve as a template in the PCR reaction. Although many RNA purification protocols claim to eliminate most of the gDNA, some residual DNA molecules may stay in the RNA extract. To solve that problem two options are available. The first eliminates any residual gDNA by addition of a DNase. When relatively big amounts of mRNA material are available for RT-PCR, this alternative is the method of choice as it is fast and efficient. However, if RT-PCR shall be employed for single cells, the first option can often not be accomplished as reverse transcription protocols for single cells are quite susceptible for errors by any changes. This especially applies for the addition of a DNase with its own buffer system. Therefore, a second option is required. One possible alternative is a procedure at which gDNA is strongly diluted and mRNA material simultaneously amplified. By this the risk of false positive results is minimized (for more detail see section 4.2).

Regarding the detection of chemoreceptor mRNA in single ORNs, another obstacle has to be overcome. Genes of ORs/V1Rs are not as highly expressed as e.g. housekeeping genes. A direct PCR may therefore not be suitable to detect all of the expressed transcripts. This implies that appropriate amplification protocols have to (i) contain successive runs of PCR and (ii) thereby employ several sets of primers covering some receptor sequences simultaneously. A double-nested PCR protocol that considers all mentioned limitations and requirements for single ORN RT-PCR was developed and is presented in section 3.1. This protocol involves four steps: In addition to reverse transcription it contains three successive PCR rounds. The first two use degenerate primers whereas specific primers are used in the third PCR.

\section{Primer design}

Primer design was initiated by screening the databases of GenBank (NCBI) and Enseml for Xenopus OR and V1R genes. The search revealed annotations to 10 complete OR genes (4 of class I; 6 of class II), 18 partial OR sequences (4 of class I; 5 of class II; 9 with no class indication) and 21 putatively functional V1 receptors. All sequences were imported and aligned using CLC Free Workbench (version 4.0.2, CLC bio, Aarhus, Denmark). The sequences were aligned according to the degree of homology. With regard to the complete OR genes, the results were in accordance to the outcome of a previous study (Mezler et al., 2001). In order to design degenerate and specific primers for the double-nested PCR, suitable template sites were searched. 
Highly conserved regions were ideal for degenerate primers whereas less conserved ones were candidates for the design of chemoreceptor-specific primers. The main challenge was to find primer combinations where the template sites of the specific primers were contained within the PCR-amplicons of PCRs where the degenerated primers were used. Receptor genes for which primers could be successfully designed were then chosen for this study and defined into three subgroups. The class I subgroup contained 8 OR sequences, class II subgroup 5 OR genes and the V1R subgroup comprised 4 sequences (Table 1). For the majority of these receptors, specific primers were created (Table 2). However, for some receptors this could not be implemented due to a high homology between the sequences. Therefore 'overlapping' primers had to be created for Xb 238/239/107 and for XR 46/106/117 (all Class I). For the $4 \mathrm{~V} 1$ receptors only degenerate primers could be designed due to a very high degree of homology between these receptor sequences.

But regarding specificity of all designed primers one notice needs to be considered with respect to the outcome of the PCR experiments. As more than 350 other ORs seem to exist in Xenopus (Niimura and Nei, 2005a) and as ORs of subfamilies are known to have several homologous regions within their sequences, it may not be excluded per se that other ORs than the ones on which was tested are additionally amplified using the designed primers. The probability of amplifying unknown OR sequences is especially enhanced for the degenerate primers. The consequence of this could be that e.g. a degenerate PCR product is detected after the second PCR round of the double-nested PCR protocol (see section 3.1) but none using specific primers in the third run. This finding may indicate that at least one receptor is expressed on which was not tested and which has most likely an unknown sequence. Regarding single cell PCR, this conclusion implies that the amount of detected PCR products can only account for the minimal number of expressed receptors.

Table 1: List of all chemoreceptors tested in this study. All sequences of the selected receptors are available in the databases of GenBank or Ensembl respectively. For X.l. sequences the GenBank accession numbers are given whereas genomic positions are indicated for X.t. V1Rs. Abbreviations: N/A, not available. 


\begin{tabular}{|c|c|c|c|c|}
\hline $\begin{array}{c}\text { Receptors } \\
\text { (human homologue) }\end{array}$ & Database & Animal & $\begin{array}{c}\text { GenBank } \\
\text { Accession number }\end{array}$ & $\begin{array}{l}\text { Location in } \\
\text { genome }\end{array}$ \\
\hline \multicolumn{5}{|l|}{ Class I } \\
\hline XR 46 & Pubmed & X.l. & Y08345 & $\mathrm{N} / \mathrm{A}$ \\
\hline XR 106 & Pubmed & X.1. & Y08346 & $\mathrm{N} / \mathrm{A}$ \\
\hline XR 117 & Pubmed & X.l. & Y08348 & $\mathrm{N} / \mathrm{A}$ \\
\hline XR 116 & Pubmed & X.1. & Y08347 & $\mathrm{N} / \mathrm{A}$ \\
\hline $\mathrm{Xb} 238$ & Pubmed & X.l. & AJ250750 & $\mathrm{N} / \mathrm{A}$ \\
\hline $\begin{array}{l}\mathrm{Xb} 239 / 107 \\
\quad(\text { or } 52 \mathrm{~d} 1)\end{array}$ & Pubmed & X.l. & AJ250751 & $\mathrm{N} / \mathrm{A}$ \\
\hline $\begin{array}{l}\text { Xb } 242 \\
\text { (or1-a) }\end{array}$ & Pubmed & X.l. & AJ250752 & $\mathrm{N} / \mathrm{A}$ \\
\hline \multicolumn{5}{|l|}{ Class II } \\
\hline $\begin{array}{l}\mathrm{Xb} 178 \\
\text { (or2-a) }\end{array}$ & Pubmed & X.l. & AJ250755 & $\mathrm{N} / \mathrm{A}$ \\
\hline $\begin{array}{l}\text { Xb } 180 \\
\text { (or2-b) }\end{array}$ & Pubmed & X.1. & AJ250756 & $\mathrm{N} / \mathrm{A}$ \\
\hline $\begin{array}{l}\text { Xb } 177 \\
(B 177-a)\end{array}$ & Pubmed & X.1. & AJ250754 & $\mathrm{N} / \mathrm{A}$ \\
\hline $\mathrm{Xb} 350$ & Pubmed & X.l. & AJ 250757 & $\mathrm{~N} / \mathrm{A}$ \\
\hline $\begin{array}{l}\mathrm{Xb} 352 \\
\text { (or1s1) }\end{array}$ & Pubmed & X.l. & AJ250758 & $\mathrm{N} / \mathrm{A}$ \\
\hline \multicolumn{5}{|l|}{ V1Rs } \\
\hline V1R10 & Ensembl & X.t. & $\mathrm{N} / \mathrm{A}$ & $\begin{array}{c}\text { Scaffold } 61 \\
\text { 1011544-1012578 }\end{array}$ \\
\hline V1R11 & Ensembl & X.t. & $\mathrm{N} / \mathrm{A}$ & $\begin{array}{c}\text { Scaffold } 61 \\
\text { 1031341-1032462 }\end{array}$ \\
\hline V1R12 & Ensembl & X.t. & $\mathrm{N} / \mathrm{A}$ & $\begin{array}{c}\text { Scaffold } 61 \\
1041747-1042718\end{array}$ \\
\hline V1R23 & Ensembl & X.t. & $\mathrm{N} / \mathrm{A}$ & $\begin{array}{c}\text { Scaffold } 3471 \\
1631-2557\end{array}$ \\
\hline
\end{tabular}


Table 2: Primer sequences for double nested PCR. All listed sequences are written from $5^{6}$ to 3 . Some degenerate primer sequences contain nucleobasemodifications, which were made according to the Invitrogen Electronic Code for Nucleobasemodifications. The resulting lengths of the PCR products are indicated in base pairs (bp). ORs which are amplified with 'overlapping' primers are separated by a slash. First, second and third run correspond to steps 2, 3 and 4 in Figure 16 (section 3.1). All primers were purchased from Invitrogen. Abbreviations: ND, not determinable.

\begin{tabular}{|c|c|c|c|}
\hline & forward primer & reverse primer & $\begin{array}{c}\text { product } \\
\text { length } \\
\text { [bp] / } \\
\text { annealing } \\
\text { Temp } \\
{\left[{ }^{\circ} \mathrm{C}\right]}\end{array}$ \\
\hline \multicolumn{4}{|c|}{$\begin{array}{l}\text { First run } \\
\text { nested PCR }\end{array}$} \\
\hline $\begin{array}{l}\text { Class I } \\
\text { subgroup }\end{array}$ & CTGATTGCAAATAGCACAG & Oligo $(\mathrm{dT})_{40}$ & $\mathrm{ND} / 45$ \\
\hline $\begin{array}{l}\text { Class II } \\
\text { subgroup }\end{array}$ & CTYATCATRGKGTTGGTGT & Oligo $(d T)_{45}$ & $\mathrm{ND} / 46$ \\
\hline $\begin{array}{l}\text { V1R } \\
\text { subgroup }\end{array}$ & AАCTAACTCCATCCTGATG & Oligo $(\mathrm{dT})_{45}$ & $\mathrm{ND} / 46$ \\
\hline \multicolumn{4}{|c|}{$\begin{array}{l}\text { Second run } \\
\text { nested PCR }\end{array}$} \\
\hline $\begin{array}{l}\text { Class I } \\
\text { subgroup }\end{array}$ & GAYTCYTTCATCMTYATGCTGATG & CHAWTARRTGRGTGGTACAGGT & $408 / 51$ \\
\hline $\begin{array}{l}\text { Class II } \\
\text { subgroup }\end{array}$ & CAGTRATGTCCTWTGACAG & TCCCGGTATTGGACACTATC & $353 / 50$ \\
\hline $\begin{array}{l}\text { V1R } \\
\text { subgroup }\end{array}$ & GCCATTGGAGTAGAAAATTTCCTGG & GGTAGAGTATGAGGTTGRCT & $225 / 51$ \\
\hline
\end{tabular}

\section{Third run}

nested PCR

\section{Class I}

XR

46/106/117

ATCAGTGATGACTTACATGATCC

AGTTGTCCGAGTGTAACATG

$232 / 49$

XR 116 
$\mathrm{Xb}$

238/239/107

ATCTGCTACTTTTGCTTGGTA

CCAAAGAAACATCAACACATG

$153 / 48$

$\mathrm{Xb} 242$

TGTTGGTTTTGGTGGCTC

CAAGGTGATATCGGCACATG

$149 / 48$

Class II

Xb 178

CTCACTTGTTCATTGCGTCTC

GACTGTAAGGTAATAGTTATCTGC

$151 / 48$

$\mathrm{Xb} 180$

TTGCTTAGCCTCATTGGCGT

CATAATATTTATATGCACCAGGTAAgtG

$152 / 48$

Xb 177

TTCAGTGAATCCAATAACAATG

ATGACTGTATGATTGCTTGTATTTG

$146 / 47$

$\mathrm{Xb} 350$

CTGCTTGGTGTTATTATAACG

ACCGACGATAAAATTACTTC

$163 / 46$

$\mathrm{Xb} 352$

AGCAAATCTAATAGGAGCATTAG

CAATGACAAGTATGAATGGTAG

$169 / 46$

$\beta$-actin (I)

TACAGCTTCACCACCACAGC

ATACCGCAGGATTCCATACC

$229 / 50$

$\beta$-actin (II)

TACAGCTTCACCACCACAGC

CAATGGTGATGACTTGTCCG

$159 / 50$

\subsubsection{RT-PCR assay using tissue of the olfactory organ}

\section{RNA isolation and Reverse Transcription}

For RNA isolation 40 animals were sacrificed and tissue, containing the olfactory organ, was cut out and stored in liquid nitrogen. According to the manufacturer's protocols, total RNA was either isolated with the Trizol method (Invitrogen, San Diego, USA) or using the RNeasy Mini Kit (Qiagen, Hilden, Germany). To remove any DNA-contaminations a subsequent DNase treatment (DNase I recombinant, RNase-free, Roche) was applied (Trizol-method). When RNA was isolated using the Mini Kit, on-column DNAse digestion (RNAse-Free DNAse Set, Qiagen) was included in the purification protocol. The RNA quality and quantity was analyzed either with the microfluidics-based electrophoresis system Agilent 2100 Bioanalyzer (Agilent Technologies, Santa Clara, USA) or by spectrophotometric analysis using a diode array spectrophotometer (WPA biowave S2100, Biochrom, Cambridge, UK). Reverse transcription was performed from RNA templates with the Omniscript RT Kit (Qiagen). For RT, $2 \mu \mathrm{g}$ of RNA was mixed with 1x PCR buffer, $500 \mu \mathrm{M}$ nucleotide mix, $0.5 \mu \mathrm{M}$ random hexamer primers, $0.5 \mu \mathrm{M}$ oligo(dT) primers, $10 \mathrm{U}$ RNase inhibitor and $4 \mathrm{U}$ Omniscript Reverse Transcriptase. Primers and RNase inhibitor were purchased from Invitrogen and Promega respectively. 
PCR

To validate OR/V1R expression two approaches were conducted. In addition to a direct PCR, a nested PCR was employed in order to verify whether the combinations of the designed primers (degenerate and specific) really work, especially with respect to the upcoming single cell PCR.

When a nested PCR approach was employed, degenerate and specific primers were used as depicted in Figure 16 (section 3.1, see steps 3, 4). For the first PCR round, 150-200 ng of cDNA from the olfactory organ were mixed with 1x PCR buffer, $200 \mu \mathrm{M}$ nucleotide mix, $200 \mathrm{nM}$ degenerate forward and reverse primers and $2 \mathrm{U}$ FastStart Taq DNA Polymerase dissolved in nuclease-free water as described in the manual (FastStart Taq DNA Polymerase, dNTPack, Roche, Mannheim, Germany; Nuclease-Free Water, Qiagen). The samples were placed in a thermocycler (TPersonal and T-Professional Basic Gradient, Biometra, Göttingen) with the following PCR conditions: Activation of DNA Polymerase at $95^{\circ} \mathrm{C}$ for 5 min was followed by 28 cycles of denaturation at $95^{\circ} \mathrm{C}$ for $30 \mathrm{~s}$, annealing at primer-specific annealing temperature for $30 \mathrm{~s}$ and extension at $72^{\circ} \mathrm{C}$ for $1 \mathrm{~min}$. PCR ended with a final elongation at $72^{\circ} \mathrm{C}$ for $7 \mathrm{~min}$. For the subsequent second PCR, a $1.5 \mu$ l aliquot of the previous run product was mixed with 1x PCR buffer, $200 \mu \mathrm{M}$ nucleotide mix, $200 \mathrm{nM}$ specific forward and reverse primers and 2 U FastStart Taq DNA Polymerase dissolved in nuclease-free water. The PCR conditions were the same as in the first PCR round.

On the contrary when a direct PCR was employed, cDNA was directly mixed with specific primers. The other PCR conditions were the same as described above. After each PCR, the amplicons were run on an ethidium bromide-containing $2 \%$ agarose gel and visualized under UV light (UVsolo, Biometra, Göttingen).

\subsubsection{RT-PCR using single ORNs}

Single ORNs of larval Xenopus were tested on expression of the selected ORs and V1Rs employing a double-nested single cell RT-PCR protocol (see section 3.1). Thereby the mRNA material was collected from cells of two different sets of experiments:

In the first set, cells were electrophysiologically identified as ORNs (see section 2.3.1) and then harvested and subjected to RT-PCR. In this set of experiments ORNs were investigated on expression of all selected chemoreceptors except Xb 350/352 and 
the V1Rs. The reasons were that by the time the experiments were conducted, primerpairs were not yet created for Xb 350/352 and V1R sequences were not yet published. However, all of the mentioned primerpairs were available before the second set of experiments was conducted.

This second set of experiments was performed in order to find odor ligands of expressed receptors. Therefore single ORNs were first preimaged on their $\left[\mathrm{Ca}^{2+}\right]_{\mathrm{i}}$ responses to three single amino acids and to a mixture of all three (see section 2.3.2). If a cell responded to at least one single amino acid and the mixture, it was subjected to RT-PCR and used for further evaluation. In order to reliably compare the outcome between both groups, OE slices of both experimental groups were stained with Fluo4/AM.

The main difficulty of cDNA synthesis from single cells is the limited amount of available mRNA. Therefore it is essential to employ a reverse transcriptase that offers high sensitivity and efficiency. Finally the SuperScript ${ }^{\mathrm{TM}}$ III First-Strand Synthesis System for RT-PCR (Invitrogen) was chosen. In order to stabilize the low amount of collected mRNAs the addition of an RNase binding agent was incorporated in the manufacturer's protocol.

\section{Reverse Transcription}

After the cell and its mRNA material were collected by a patch pipette, the content of the pipette (internal solution + one individual cell) was expelled into a tube containing $50 \mu \mathrm{M}$ oligo $(\mathrm{dT})_{20}$ primer, $40 \mathrm{U}$ RNasin Plus RNase Inhibitor (Promega, Mannheim, Germany), $1 \mathrm{mM}$ dNTP mix and DEPC-treated water. The tube was incubated at $65^{\circ} \mathrm{C}$ for 5 minutes and then placed on ice for at least 1 minute. Before and during this heating process RNasin inactivated RNases and thereby protected the collected mRNA. Subsequently, reverse transcription was performed by adding $2 \mathrm{x}$ RT buffer, $10 \mathrm{mM} \mathrm{MgCl}$, $20 \mathrm{mM}$ DTT, $4 \mathrm{U}$ RNaseOUT, $20 \mathrm{U}$ SuperScript III reverse transcriptase and incubating the mixture in a thermocycler at $50^{\circ} \mathrm{C}(50 \mathrm{~min})$ and $85^{\circ} \mathrm{C}$ ( 5 min). The tubes were then chilled on ice for at least 2 min. Remaining RNA was degraded by adding $1 \mathrm{U}$ RNase $\mathrm{H}$ and incubating the tubes for $20 \mathrm{~min}$ at $37^{\circ} \mathrm{C}$. The total volume of each tube was $20 \mu \mathrm{l}$. Negative control reactions without reverse transcriptase were regularly performed. 


\section{Double-nested PCR}

For cDNA amplification (section 3.1, see Figure 16, step 2), $4 \mu$ of the reverse transcribed material were mixed with 1x PCR buffer, $200 \mu \mathrm{M}$ nucleotide mix, $200 \mathrm{nM}$ degenerate forward and oligo(dT) reverse primers and 2 U FastStart Taq DNA Polymerase dissolved in nuclease-free water as described in the manual (see above). The samples were placed in a thermocycler with the following PCR conditions: Activation of DNA Polymerase at $95^{\circ} \mathrm{C}$ for 5 min was followed by 40 cycles of denaturation at $95^{\circ} \mathrm{C}$ for $30 \mathrm{~s}$, annealing at primer-specific annealing temperature for $30 \mathrm{~s}$ and extension at $72^{\circ} \mathrm{C}$ for $3 \mathrm{~min}$. PCR ended with a final elongation at $72^{\circ} \mathrm{C}$ for 7 min. The total volume of each tube was $50 \mu \mathrm{l}$

For the following second PCR (Figure 16, step 3), a $4 \mu$ l aliquot of the previous run product was mixed with 1x PCR buffer, $200 \mu \mathrm{M}$ nucleotide mix, $200 \mathrm{nM}$ degenerate forward and reverse primers and 2 U FastStart Taq DNA Polymerase dissolved in nuclease-free water. The PCR conditions were the same as in the first PCR round, except the number of cycles, which was set to 42 and the extention time, which was reduced to $1 \mathrm{~min}$.

PCR products were then run on an ethidium bromide-containing $2 \%$ agarose gel and visualized under UV light. When a product was detected, $3 \mu \mathrm{l}$ of this PCR product were used for a third PCR (Figure 16, step 4). They were mixed with 1x PCR buffer, $200 \mu \mathrm{M}$ nucleotide mix, $200 \mathrm{nM}$ specific forward and reverse primers and $2 \mathrm{U}$ FastStart Taq DNA Polymerase dissolved in nuclease-free water. PCR cylces were reduced to 37 with the remaining conditions being not altered. The sequences of the degenerate and specific primers for each PCR run are depicted in Table 2.

In order to validate that mRNA of ORNs was indeed transcribed, intron-spanning primers of the housekeeping gene $\beta$-actin (Table 1; Hagino-Yamagishi, 2004) were tested. ORNs of the first set of experiments were thereby tested on $\beta$-actin by a direct PCR (see $\beta$-actin I primers, Table 2) whereas ORNs that were collected after calcium-imaging were subjected to a nested PCR approach ( $\beta$-actin I+II primers). This was done as nested $\beta$-actin primers were just found during the progress of this study and seemed to be more sensitive to detect the housekeeping gene. For PCR, 4 $\mu \mathrm{l}$ of the reverse transcribed material were subjected to the same condition as described above for the second and third PCR run. 


\subsection{Solutions, odorants and stimulus application}

\subsubsection{Bathing and internal solutions}

The compositions of the bath and internal solutions are listed in Table 3. All of the chemicals used for the preparation of both solutions were purchased from Merck (Darmstadt, Germany) or Sigma (St Louis, MO, USA). All solutions, including the HEPES buffer, were adjusted to $\mathrm{pH}$ 7.8. After the preparations, bath solution was stored in a fridge whereas internal solution was aliquoted and freezed at $-20^{\circ} \mathrm{C}$. Before use, both solutions were filtered using Sartolab RF 500 (bath solution) and Minisart RC 4 (internal solution) filter units (Sartorius, Göttingen, Germany).

Table 3: Composition of bath and internal solutions.

\begin{tabular}{|c|c|c|}
\hline \multirow[t]{2}{*}{ Substance } & \multicolumn{2}{|c|}{ Concentration } \\
\hline & Bathing solution & Intracellular solution \\
\hline $\mathrm{NaCl}$ & $98 \mathrm{mM}$ & $2 \mathrm{mM}$ \\
\hline $\mathrm{KCl}$ & $2 \mathrm{mM}$ & $11 \mathrm{mM}$ \\
\hline $\mathrm{CaCl}_{2}$ & $1 \mathrm{mM}$ & - \\
\hline $\mathrm{MgCl}_{2}$ & $2 \mathrm{mM}$ & - \\
\hline $\mathrm{MgSO}_{4}$ & - & $2 \mathrm{mM}$ \\
\hline K-gluconate & - & $80 \mathrm{mM}$ \\
\hline Na-pyruvate & $5 \mathrm{mM}$ & - \\
\hline Glucose & $5 \mathrm{mM}$ & - \\
\hline HEPES & $10 \mathrm{mM}$ & $10 \mathrm{mM}$ \\
\hline EGTA & - & $0.2 \mathrm{mM}$ \\
\hline $\mathrm{Na}_{2}-\mathrm{ATP}$ & - & $1 \mathrm{mM}$ \\
\hline $\mathrm{Na}_{2}-\mathrm{GTP}$ & - & $0.1 \mathrm{mM}$ \\
\hline \multicolumn{3}{|l|}{ Adjusted to } \\
\hline $\mathrm{X}$ mOsmol/l & 230 & 190 \\
\hline
\end{tabular}




\subsubsection{Odorant stimuli}

For odorants three amino acids (L-arginine, L-methionine, L-lysine; Sigma) were used and either applied as a mixture or as single stimuli. Amino acids are well known to be suitable odorants for aquatic species (Caprio and Byrd, 1984; Iida and Kashiwayanagi, 1999; Manzini et al., 2002). In every experiment the individual amino acids and the mixture were applied in random order. The amino acids were dissolved in bath solution (10 mM stock, each) and kept frozen until usage $\left(-20^{\circ} \mathrm{C}\right)$. In all of the experiments they were used at a final concentration of $200 \mu \mathrm{M}$ each. Amino acids were prepared immediately before use by dissolving the respective stock in bath solution.

\subsubsection{The application system}

In patch-clamp and calcium imaging experiments the bath solution and the odorant stimuli were both applied to the recording chamber by gravity feed from a storage syringe through a funnel drug applicator (Figure 15; Schild, 1985). Odorants were pipetted directly into the funnel without stopping the continuous flow of bath solution. Outflow was through the tip of the outlet tube, which was placed in close vicinity to the olfactory epithelium. The dilution of the stimulus within the funnel was less than 1\% (Manzini and Schild, 2003a). After each stimulus application the wall of the funnel was rinsed by washing with bath solution. By this application system numberless odorant stimuli can be applied and mechanosensitive responses of receptor neurons can be prevented. The minimum stimulus interval was 2 minutes. 


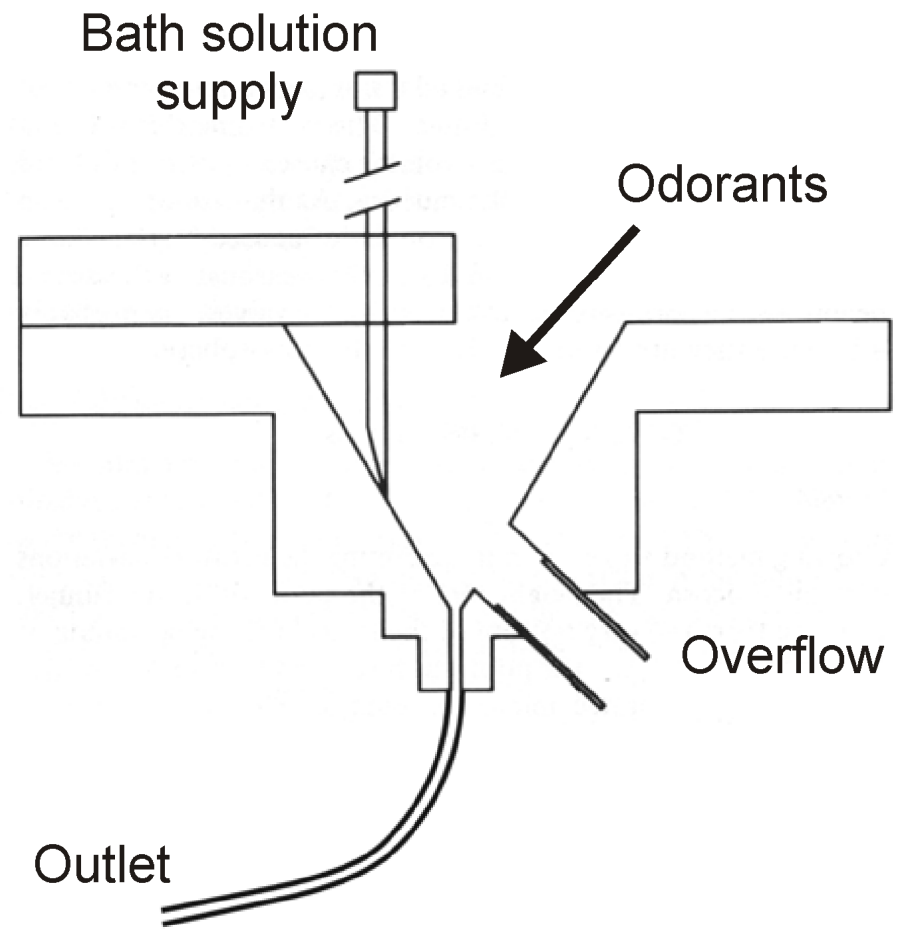

Figure 15: Schematic drawing of the application system. Bath solution and odorants are applied into the funnel with some solution exiting via the outlet to the recording chamber. Figure modified after Schild, 1985. 


\subsection{Biocytin/cytokeratin staining of the olfactory epithelium and biocytin/calretinin/DAPI staining of the olfactory bulb}

Xenopus laevis tadpoles were anaesthetized as described in section 2.2. For staining of the olfactory epithelia, the olfactory nerves were cut through and crystals of biocytin ( $\varepsilon$-biotinoyl- ${ }_{\mathrm{L}}$-lysine, Molecular Probes) were put into the lesioned site. The wound was closed by histoacryl glue (B. Braun Aesculap, Tuttlingen, Germany). To allow for nerve backfilling, the animals were put back in the water for at least 1.5 hours before they were sacrificed and a block of tissue containing the olfactory epithelia, the olfactory nerves and the anterior part of the brain was cut out. The blocks were fixed in $4 \%$ paraformaldehyde (PFA) for 2 hours at room temperature, which was followed by fixation in $30 \%$ saccharose for 3 days at $4^{\circ} \mathrm{C}$. Using a cryostat (SM 1850, Leica), sections were sliced at about $10 \mu \mathrm{m}$ and fixed on object slides. They were washed in PBS containing $0.2 \%$ Triton X-100 (PBST) and the tissue was incubated in ALEXA 546 conjugated streptavidin (Molecular Probes; 1:100 in PBST) over night at $4^{\circ} \mathrm{C}$. Slices were then washed in PBST and nonspecific binding was blocked with $2 \%$ normal goat serum (NGS; ICN, Aurora, Ohio, USA) for 1 hour at room temperature. Sections were then incubated overnight at $4^{\circ} \mathrm{C}$ with a primary monoclonal mouse antibody against Xenopus laevis cytokeratin II (Developmental Studies Hybridoma Bank, University of Iowa, USA; 1:2000 in 2\% NGS/PBST). The primary antibody was then washed off with PBS and ALEXA 488 conjugated anti-mouse antibody (Molecular Probes; 1:250 in 1\% NGS/PBS) was applied for 2 hours at room temperature. After the secondary antibody was washed off in several changes of PBS, the slices were mounted in mounting medium (Dako, Hamburg, Germany).

For immunostaining the $\mathrm{OB}$, tadpoles were electroporated with biocytin within their nasal cavities. The animals were anaesthetized with $0.02 \%$ tricaine (Sigma) prior to this procedure. Electroporation was perfomed using a custom build device (Kludt, 2009). First, biocytin crystals were placed in the nasal cavities. After the crystals had dissolved, two platinum wire electrodes were put in both nasal cavities. Twelve square pulses of $30 \mathrm{~V}$ and $20 \mathrm{~ms}$ duration were manually applied at about $1 \mathrm{~Hz}$ and with alternating polarity. The animals were put back in the water and sacrificed about 2 hours after electroporation. A block of tissue containing the olfactory epithelia, the olfactory nerves and anterior part of the brain was cut out. The fixation steps, sectioning, streptavidin staining and NGS blocking was done the same way as for OE slices. In order to visualize the projections of the VNO axons, sections were incubated overnight at $4^{\circ} \mathrm{C}$ with a primary rabbit monoclonal antibody against calretinin 
(Abcam, Cambridge, UK; 1:1000 in 2\% NGS/PBST). The primary antibody was then washed off with PBS and an ALEXA 488 conjugated anti-rabbit antibody (Molecular Probes; 1:250 in 1\% NGS/PBS) was applied for 2 hours at room temperature. After washing off the secondary antibody in PBS, the sections were incubated for 15 minutes with DAPI (Sigma; 1:500) and finally mounted in mountin medium (Dako). All preparations were viewed and imaged under a laser scanning confocal microscope (LSM 510/Axiovert 100, Zeiss). 


\section{3}

\section{RESULTS}

\subsection{Double-nested RT-PCR}

In the following I describe the method that was developed for RT-PCR using single ORNs.

If reverse transcription-PCR (RT-PCR) is employed to investigate the expression of $\mathrm{OR}$ and V1R genes, the caveat of false positive results by contaminating gDNA will need to be considered as chemoreceptor genes consist of only one exon. When much mRNA material, e.g. the whole olfactory organ, is available for RT-PCR, gDNA can simply be digested using DNAses. But when material from just a single cell is available, a more sophisticated approach is required (see section 2.4.1). A double-nested RT-PCR protocol, which considers these obstacles, was developed for single ORNs and is presented in Figure 16.

The first step in this protocol is to reverse transcribe all collected mRNAs using oligo(dT) primers (for details see section 2.4.3). The second step, at which gDNA is strongly diluted and cDNA simultaneously amplified, uses degenerate forward and oligo(dT) reverse primers (see Table 2). The degenerate forward primers thereby produce the complement strand of the cDNA. Subsequently, both forward and reverse primers anneal to cDNA material. Since the oligo(dT) primer anneals at the Poly $(A)$ tail of the complementary cDNA strand, but not at a gDNA template, just cDNAs of olfactory and vomeronasal receptors will be amplified. The third step aims to further amplify even low amounts of all expressed receptor transcripts to which the degenerate primers potentially annealed. This goal is achieved by an amplification of respective targets within the previous PCR product using another set of degenerate OR/V1R primers. In the fourth step, primers being specific for certain chemoreceptor sequences are employed to show whether a particular receptor is contained in the previous PCR product. This step is only carried out when a degenerate product has been detected by agarose-gelelectrophoresis after the $2^{\text {nd }} P C R$. 


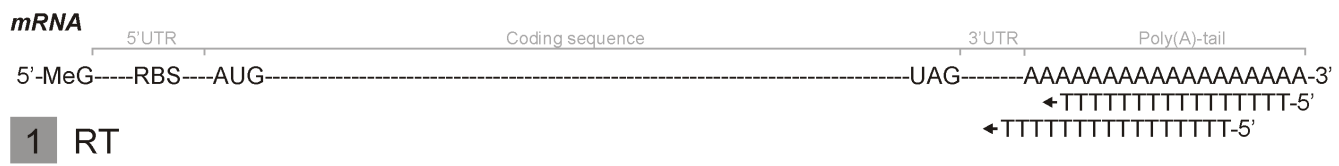

CDNA
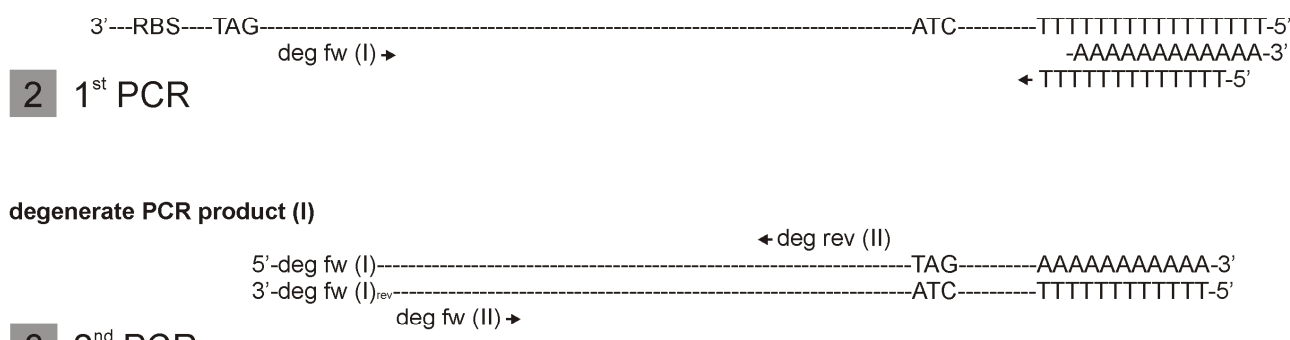

$32^{\text {nd }} \mathrm{PCR}$

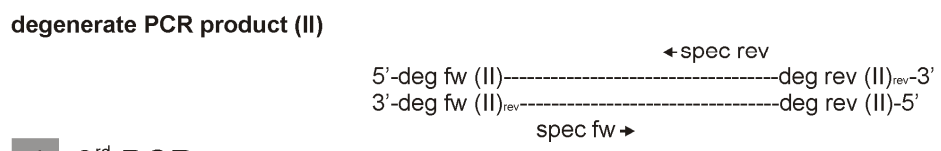

$43^{\text {rd }}$ PCR

specific PCR product

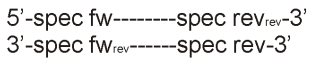

Figure 16: Reverse transcription and double nested PCR.

Reverse transcription using oligo $(\mathrm{dT})_{20}$ primer (1) was followed by amplification of cDNA using a degenerate forward primer for ORs/V1Rs (fw I) and a reverse oligo $(\mathrm{dT})_{40 / 45}$ primer (2). A second set of degenerate primers for ORs and V1Rs (fw II, rev II) was used for amplification of a target sequence within the previous PCR product (3). Specific PCRproducts were obtained with gene specific primers (4).

Abbreviations: UTR, untranslated region; MeG, methylguanosin; RBS, ribosomal entry site; AUG, adenosine uracil guanosin (startcodon); UAG, uracil adenosin guanosin (stopcodon); RT, reverse transcription; deg, degenerate; fw, forward; rev, reverse; spec, specific. 


\subsection{Expression of chemoreceptors in the olfactory epithelium of Xenopus laevis tadpoles}

Olfactory and vomeronasal type 1 receptors were both shown to be expressed in the main olfactory epithelium of Xenopus laevis (Freitag et al., 1995; Mezler et al., 2001; Date-Ito et al., 2008). The onset of class I and class II OR expression was thereby shown to be from stage 39 and 49 respectively (Mezler et al., 2001). Therefore it was probable that at least some receptors are expressed in the OE of the investigated larval stages (52-54). In order to validate expression of some selected ORs and V1Rs, mRNA content of the olfactory organ was analyzed using a nested RT-PCR. By this method it was investigated (i) whether the designed primer work as predicted and (ii) which of the chemoreceptors are expressed during the investigated stages.

As agarose gelelectrophoresis revealed a product after each PCR, the results validated mRNA for almost all tested ORs and V1Rs (Figure 17). Direct sequencing of the PCR products (Seqlab Sequence Laboratories, Göttingen, Germany) verified the specificity of the selected primers at DNA level (Supplementary figures 1-3). Regarding ORs, the sequence identity was at least 99\%, whereas the PCR product for X.1. V1Rs showed a sequence identity of up to $90 \%$ compared to each of the four Xenopus tropicalis (X.t.) V1Rs. With respect to the PCR-product obtained with the $\mathrm{Xb}$ 238/239/107 primer, sequencing revealed expression of only Xb 238.

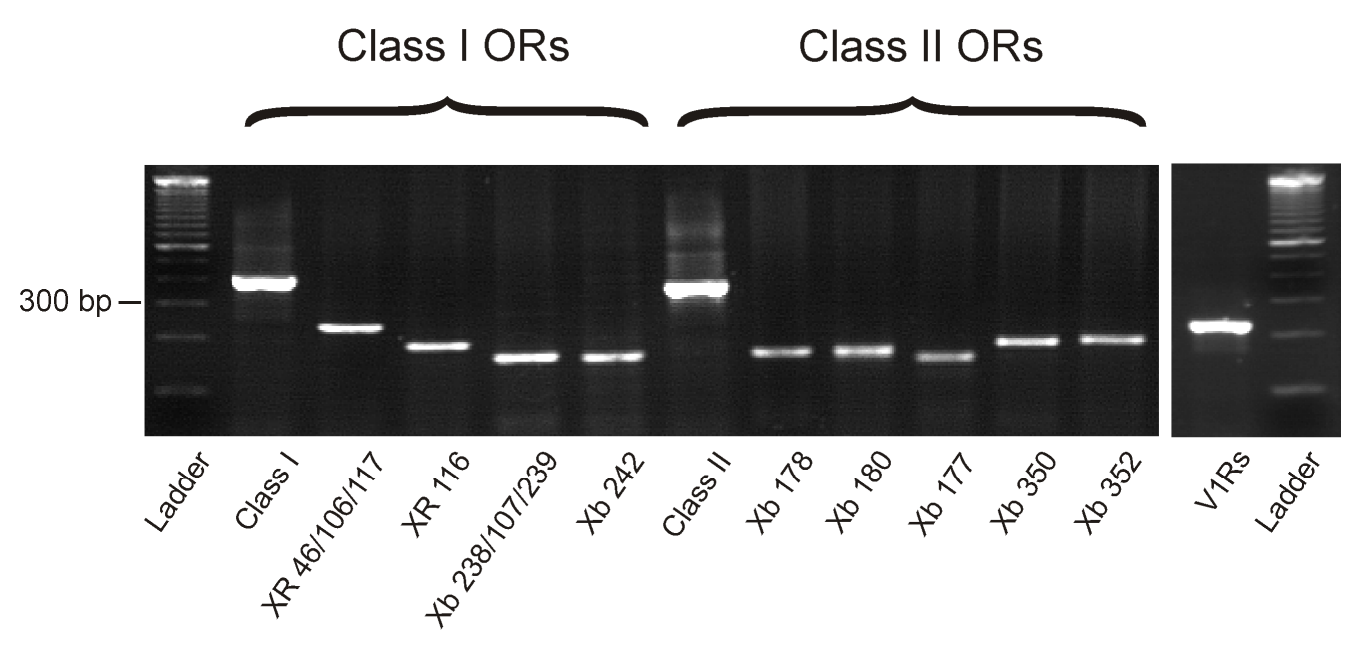

Figure 17: Identification of OR and V1R mRNA in the olfactory organ of larval Xenopus laevis (stages 52-54). The PCR products Class I, II and VIR were obtained with degenerate primers. 


\subsection{Expression of multiple receptors in single receptor neurons}

The above data demonstrated expression of almost all investigated ORs and V1Rs and that the designed primers work in a nested RT-PCR. Subsequently, the question whether an ORN expresses more than one OR/V1R gene simultanously was approached by two independent sets of experiments. Thereby ORNs were identified and collected either in patch-clamp or calcium imaging experiments.

\subsubsection{Patch-clamp measurements of single ORNs}

In acute OE slice preparations, cells were patch-clamped and identified as ORNs by the oberservation of spontaneous spiking acitivity in the on-cell mode and typical voltage-gated inward sodium and outward potassium currents in the whole-cell configuration (Figure 18). After cytoplasm was allowed to diffuse into the pipette during whole-cell mode, the single cell was collected from the OE under optical and electrophysiological control.

A

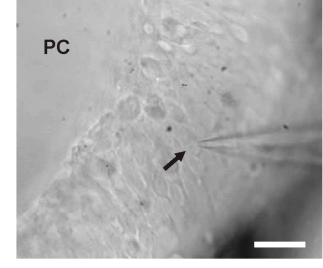

C

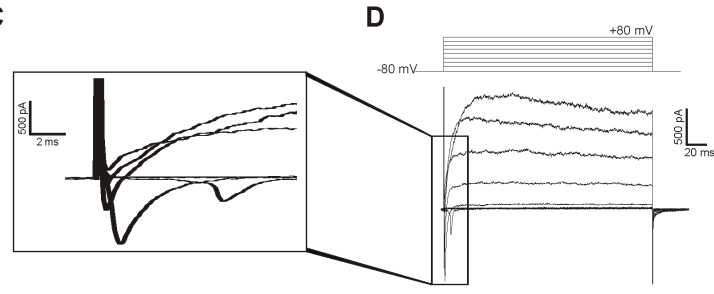

B
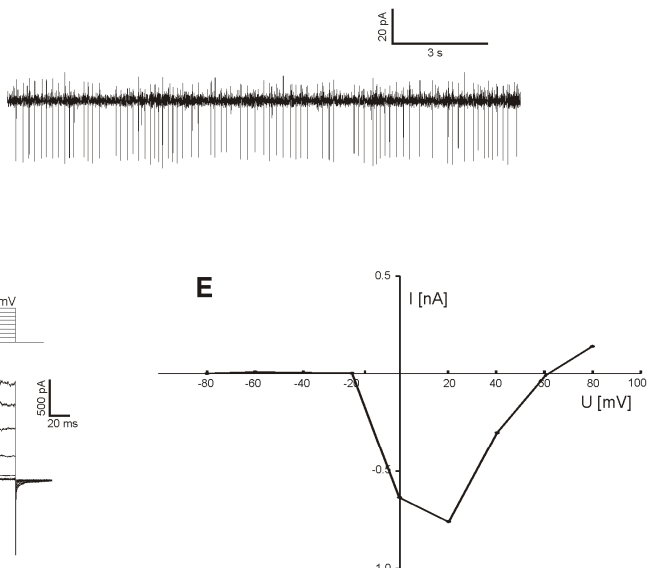

Figure 18: Patch-clamp recordings from a single ORN. (A,B) After an ORN was patchclamped, the holding potential was set to $0 \mathrm{mV}$ which normally resulted in spontaneous electrical activity in intact ORNs. (C-D) In the whole-cell mode net inward and outward currents (lower traces) were recorded, triggered by $200 \mathrm{~ms}$ step depolarizations to the potentials indicated (upper traces, D). (E) A current-voltage (I-V) curve illustrates the relationship between the electric currents and the corresponding voltages shown in D. Abbreviations: PC, principal cavity; Scale bar, $20 \mu \mathrm{m}$. 


\subsubsection{Simultaneous expression of multiple ORs in individual ORNs}

After the single cells were collected, they were subjected to reverse transcription. Altogether 55 cells were patch-clamped and harvested ( $n=12$ slices). Out of these, 44 cells were reverse transcribed whereas 11 were used as negative controls. In total, PCR-amplified OR products were found in 16 ORNs (Table 4). Reverse transcription was validated in all of these cells by the detection of $\beta$-actin.

Table 4: OR-expression patterns of reverse transcribed ORNs. The table shows which ORs are expressed in 16 reverse transcribed cells. An "X" indicates "OR-expression"; a blank field indicates "no OR-expression". PCR products Cl I and II were obtained with deg. primers.

\begin{tabular}{|c|c|c|c|c|c|c|c|c|c|c|}
\hline \multicolumn{7}{|c|}{ Class I ORs } & \multicolumn{5}{|c|}{ Class II ORs } \\
\hline $\begin{array}{c}\text { ORN } \\
\text { \# }\end{array}$ & $\begin{array}{c}\beta- \\
\text { actin }\end{array}$ & Cl I & $\begin{array}{c}\text { XR } \\
46 / 106 / 117\end{array}$ & $\begin{array}{c}\text { XR } \\
116\end{array}$ & $\begin{array}{c}\text { Xb } \\
238 / 239 / 107\end{array}$ & $\begin{array}{c}\text { Xb } \\
242\end{array}$ & Cl II & $\begin{array}{c}\text { Xb } \\
178\end{array}$ & $\begin{array}{c}\text { Xb } \\
180\end{array}$ & $\begin{array}{c}\text { Xb } \\
177\end{array}$ \\
\hline 1 & $\mathrm{X}$ & $\mathrm{X}$ & & $\mathrm{X}$ & $\mathrm{X}$ & $\mathrm{X}$ & $\mathrm{X}$ & $\mathrm{X}$ & & $\mathrm{X}$ \\
\hline 2 & $\mathrm{X}$ & & & & & & $\mathrm{X}$ & & & \\
\hline 3 & $\mathrm{X}$ & & & & & & $\mathrm{X}$ & & $\mathrm{X}$ & \\
\hline 4 & $\mathrm{X}$ & & & & & & $\mathrm{X}$ & & & \\
\hline 5 & $\mathrm{X}$ & & & & & & $\mathrm{X}$ & $\mathrm{X}$ & $\mathrm{X}$ & $\mathrm{X}$ \\
\hline 6 & $\mathrm{X}$ & & & & & & $\mathrm{X}$ & $\mathrm{X}$ & $\mathrm{X}$ & $\mathrm{X}$ \\
\hline 7 & $\mathrm{X}$ & $\mathrm{X}$ & & $\mathrm{X}$ & & $\mathrm{X}$ & $\mathrm{X}$ & & & \\
\hline 8 & $\mathrm{X}$ & $\mathrm{X}$ & & $\mathrm{X}$ & & & $\mathrm{X}$ & & & \\
\hline 9 & $\mathrm{X}$ & $\mathrm{X}$ & $\mathrm{X}$ & $\mathrm{X}$ & & $\mathrm{X}$ & & & & \\
\hline 10 & $\mathrm{X}$ & & & & & & $\mathrm{X}$ & & & \\
\hline 11 & $\mathrm{X}$ & & & & & & $\mathrm{X}$ & $\mathrm{X}$ & & \\
\hline 12 & $\mathrm{X}$ & $\mathrm{X}$ & $\mathrm{X}$ & $\mathrm{X}$ & & $\mathrm{X}$ & & & & \\
\hline 13 & $\mathrm{X}$ & $\mathrm{X}$ & & & & & $\mathrm{X}$ & & & \\
\hline 14 & $\mathrm{X}$ & $\mathrm{X}$ & & & & & & & & \\
\hline 15 & $\mathrm{X}$ & & & & & & $\mathrm{X}$ & & & \\
\hline 16 & $\mathrm{X}$ & $\mathrm{X}$ & & & & & & & & \\
\hline
\end{tabular}


With regard to the amount of PCR products that were found per single cell, several ORNs seemed to contain more than one kind of chemoreceptor transcript. One example for this striking finding is shown in Figure 19 (A, B), where the PCR products obtained from a single receptor neuron (\#6, Table 4) are depicted. This particular cell showed expression of $\beta$-actin and the tested class II subgroup but not of class I. A subsequent PCR then revealed that this receptor neuron expressed three of the tested ORs, namely Xb 178, Xb 180 and Xb 177. Direct sequencing of the $\beta$ actin and OR fragments validated this finding (Supplementary figure 4). In total, specificity of PCR products was reconfirmed for 6 more PCR products (not shown). Regarding possible contamination derived from gDNA, no PCR product was observed in those samples that had not undergone the reverse transcriptase reaction (Figure 19, C).

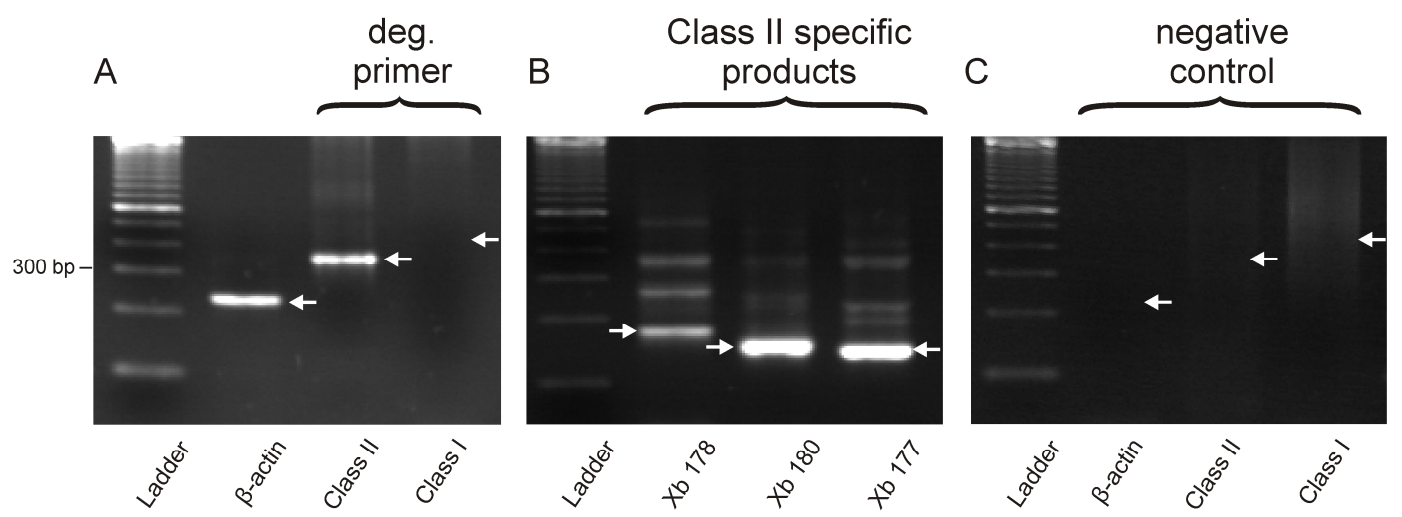

Figure 19: Expression of multiple ORs per single ORN. (A) Single cell RT-PCR revealed mRNA of $\beta$-actin and class II ORs but not of class I ORs. (B) A subsequent PCR with specific primers for class II ORs showed expression of Xb 178 Xb 180 and Xb 177 (6). (C) In contrast, no PCR products were obtained from ORNs that had not undergone reverse transcription.

Concerning the amplicons of all ORNs, the frequency by which a PCR product was found was highest for Class II degenerate primers and lowest for Xb 238/239/107 primers (for more details see Figure 20). For eight investigated ORNs expression of at least two ORs could be observed (Figure 21). Out of these, six ORNs were found that expressed a minimum of three receptors. One cell even expressed at least five receptors. 


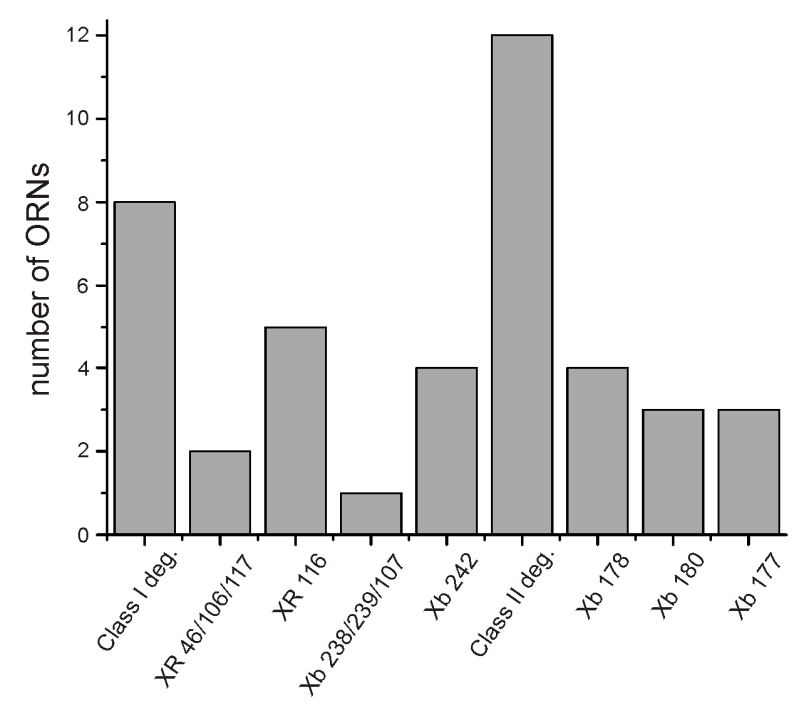

Figure 20: Frequency of OR-expression in single ORNs. The histogram shows for each of the employed primers in how many of the 16 ORNs a PCR product was found. ORexpression in detail: Class I degenerate primers $=8$ ORNs; XR 46/106/117 = 2 ORNs; $\mathrm{XR} 116=5$ ORNs; Xb 238/239/107 = 1 ORNs; Xb $242=4$ ORNs; Class II degenerate primers $=12$ ORNs; Xb $178=4$ ORNs; Xb $180=3$ ORNs; Xb $177=3$ ORNs.

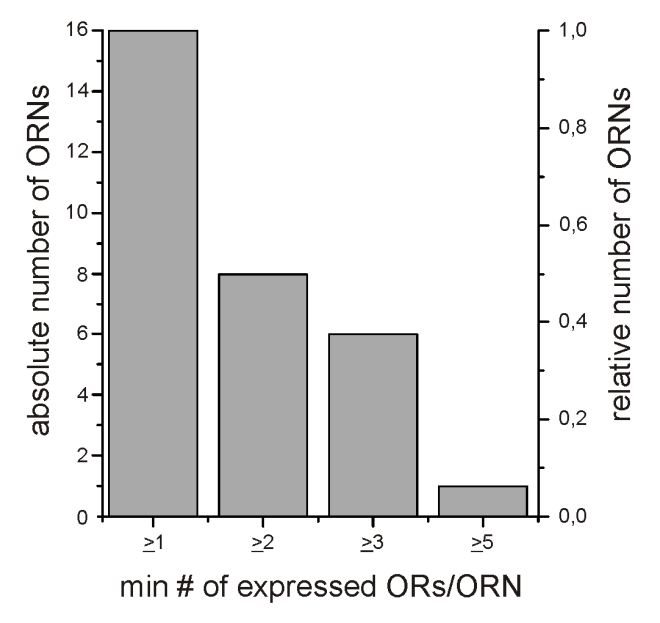

Figure 21: Rate of expressed OR per ORN. PCR products of ORs were found in 16 cells ( $\mathrm{n}=12$ slices). Half of them expressed at least two receptors. A minimum of three expressed ORs was found in six of these, while one cell expressed at least five receptors. 


\subsubsection{Calcium imaging of ORNs}

In order to obtain a more detailed understanding about the ligand-sensitivities of the expressed receptors, it was reasoned that an odorant response assay, combined with single cell RT-PCR, would lead to a correlation between the physiological responses and the investigated receptors. Amino acids were selected as odorants as they are well known olfactory stimuli in larval Xenopus laevis (Manzini et al., 2002; Manzini et al., 2003a). In this study, ORNs of Fluo-4/AM stained slices were stimulated with three amino acids, namely arginine, lysine and methionine. These amino acids were chosen based on a previous study that predicted a subset of ORNs expressing at least two olfactory receptors that exhibit different sensitivities to these three stimuli (Gutermann, 2006). In addition, the use of three stimuli implied a differentiated response spectrum with up to 7 possible patterns. With respect to the application, the odorant stimuli were applied separately as well as a mixture of all three $(200 \mu \mathrm{M}$ each). After $\left[\mathrm{Ca}^{2+}\right]_{\mathrm{i}}$ transients were recorded, responsive ORNs were collected and subjected to reverse transcription (see section 2.4.3). Figure 22 illustrates this procedure. For demonstration purposes the pipette was filled with fluorescein. The Figure depicts the increase in $\left[\mathrm{Ca}^{2+}\right]_{\mathrm{i}}$ upon stimulus application (Figure 22, C) and illustrates that the responsive cell was individually collected from the tissue slice (D).
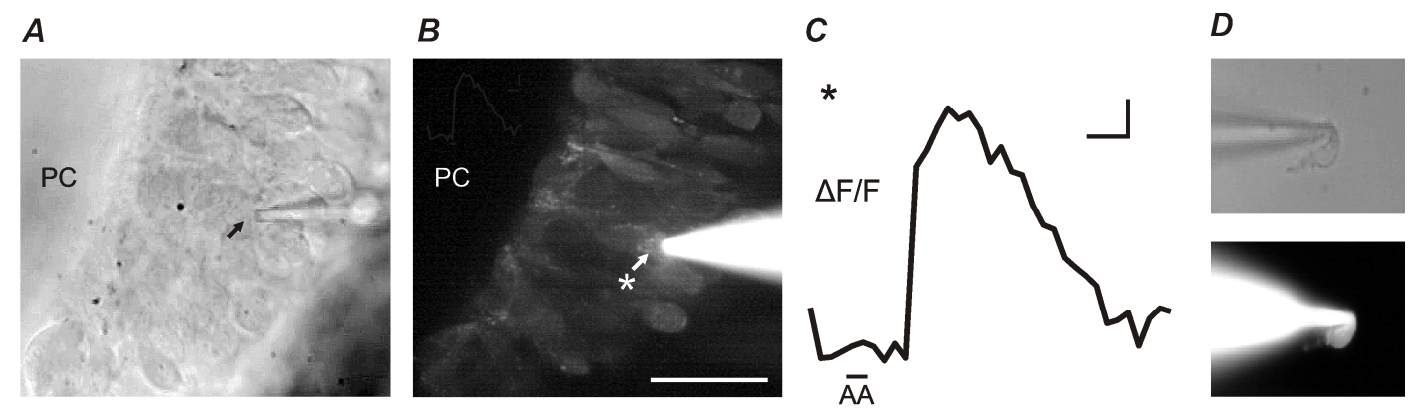

Figure 22: Calcium imaging and cell harvesting. (A) Widefield image showing an acute slice of the $\mathrm{OE}$ with a patch pipette on an individual receptor neuron (arrow). (B) Fluorescence image showing the odorant response of this ORN was determined by calcium imaging of the Fluo-4/AM-stained slice. (C) Time course of $\left[\mathrm{Ca}^{2+}\right]_{\mathrm{i}}$ transients of the cell marked in B evoked by application of amino acids. (D) Responsive cells were individually collected with a patch pipette. Abbreviations: PC, principal cavity; AA, amino acids. Scale bars, $20 \mu \mathrm{m}(\mathrm{B}), 5 \mathrm{~s}$ and $\Delta \mathrm{F} / \mathrm{F} 10 \%(\mathrm{C})$. 


\subsubsection{RT-PCR analysis of preimaged ORNs}

Altogether 45 receptor neurons were harvested ( $\mathrm{n}=11$ slices). Out of these, 34 cells were reverse transcribed whereas 11 were used as negative controls. In total, $\beta$-actin was detected in 14 ORNs whereas PCR-amplified OR/V1R products were found in 10 of these. Expressed receptors and response profiles of these cells are shown in Table 5.

Table 5: OR/V1R-expression patterns of preimaged ORNs. The table shows which ORs are expressed in 14 reverse transcribed cells. An "X" indicates "OR-expression"; a blank field indicates "no OR-expression". In addition, response profiles of these ORNs are depicted. An "O" indicates a "response" to a particular stimulus; a blank field indicates "no response". Abbreviations: VR, vomeronasal receptor; Arg, arginine; Met, methionine; Lys, lysine; Mix, Arg+Met+Lys. PCR products Cl I and II were obtained with degenerate primers.

\begin{tabular}{|c|c|c|c|c|c|c|c|c|c|c|c|c|c|c|c|c|c|}
\hline & & \multicolumn{5}{|c|}{ Class I ORs } & \multicolumn{6}{|c|}{ Class II ORs } & VR & \multicolumn{4}{|c|}{ Odorant stimuli } \\
\hline $\begin{array}{c}\text { ORN } \\
\#\end{array}$ & $\begin{array}{c}\beta- \\
\text { actin }\end{array}$ & $\mathrm{Cl} \mathrm{I}$ & $\begin{array}{c}\text { XR } \\
46 / \\
106 / \\
117\end{array}$ & $\begin{array}{l}\text { XR } \\
116\end{array}$ & $\begin{array}{c}\mathrm{Xb} \\
238 / \\
239 / \\
107\end{array}$ & $\begin{array}{l}\mathrm{Xb} \\
242\end{array}$ & Cl II & $\begin{array}{l}\mathrm{Xb} \\
178\end{array}$ & $\begin{array}{l}\mathrm{Xb} \\
180\end{array}$ & $\begin{array}{l}\mathrm{Xb} \\
177\end{array}$ & $\begin{array}{l}\mathrm{Xb} \\
350\end{array}$ & $\begin{array}{l}\mathrm{Xb} \\
352\end{array}$ & $\begin{array}{l}\text { V1R } \\
\text { Deg }\end{array}$ & $\operatorname{Arg}$ & Met & Lys & Mix \\
\hline 1 & $\mathrm{X}$ & & & & & & $\mathrm{X}$ & & & & & & & & $\mathrm{O}$ & & $\mathrm{O}$ \\
\hline 2 & $\mathrm{X}$ & & & & & & $\mathrm{X}$ & & $\mathrm{X}$ & $\mathrm{X}$ & & & & $\mathrm{O}$ & $\mathrm{O}$ & & $\mathrm{O}$ \\
\hline 3 & $\mathrm{X}$ & & & & & & & & & & & & & & $\mathrm{O}$ & & $\mathrm{O}$ \\
\hline 4 & $\mathrm{X}$ & & & & & & $\mathrm{X}$ & & & & & & & $\mathrm{O}$ & & & $\mathrm{O}$ \\
\hline 5 & $\mathrm{X}$ & & & & & & & & & & & & & & $\mathrm{O}$ & & $\mathrm{O}$ \\
\hline 6 & $\mathrm{X}$ & & & & & & $\mathrm{X}$ & & & $\mathrm{X}$ & $\mathrm{X}$ & & $\mathrm{X}$ & $\mathrm{O}$ & $\mathrm{O}$ & & $\mathrm{O}$ \\
\hline 7 & $\mathrm{X}$ & & & & & & $\mathrm{X}$ & & $\mathrm{X}$ & & & & $\mathrm{X}$ & $\mathrm{O}$ & & & $\mathrm{O}$ \\
\hline 8 & $\mathrm{X}$ & & & & & & & & & & & & $\mathrm{X}$ & $\mathrm{O}$ & $\mathrm{O}$ & & $\mathrm{O}$ \\
\hline 9 & $\mathrm{X}$ & & & & & & & & & & & & & & $\mathrm{O}$ & & $\mathrm{O}$ \\
\hline 10 & $\mathrm{X}$ & & & & & & $\mathrm{X}$ & & & & & & & $\mathrm{O}$ & $\mathrm{O}$ & $\mathrm{O}$ & $\mathrm{O}$ \\
\hline 11 & $\mathrm{X}$ & $\mathrm{X}$ & & $\mathrm{X}$ & $\mathrm{X}$ & & $\mathrm{X}$ & & & & & & $\mathrm{X}$ & $\mathrm{O}$ & $\mathrm{O}$ & $\mathrm{O}$ & $\mathrm{O}$ \\
\hline 12 & $\mathrm{X}$ & $\mathrm{X}$ & & $\mathrm{X}$ & $\mathrm{X}$ & $\mathrm{X}$ & $\mathrm{X}$ & & X & $\mathrm{X}$ & & & $\mathrm{X}$ & $\mathrm{O}$ & $\mathrm{O}$ & $\mathrm{O}$ & $\mathrm{O}$ \\
\hline 13 & $\mathrm{X}$ & & & & & & $\mathrm{X}$ & & $\mathrm{X}$ & & & & $\mathrm{X}$ & & $\mathrm{O}$ & $\mathrm{O}$ & $\mathrm{O}$ \\
\hline 14 & $\mathrm{X}$ & & & & & & & & & & & & & $\mathrm{O}$ & & & $\mathrm{O}$ \\
\hline
\end{tabular}


The frequency by which a PCR product was found in reverse transcribed cells was highest for Class II degenerate primers. No PCR products were found for XR 46/106/117, Xb 178 and Xb 352 (for more details see Figure 23). For six investigated ORNs expression of at least two ORs could be observed (Figure 24). Out of these, two ORNs were found that expressed a minimum of five receptors. One cell even expressed at least six receptors.

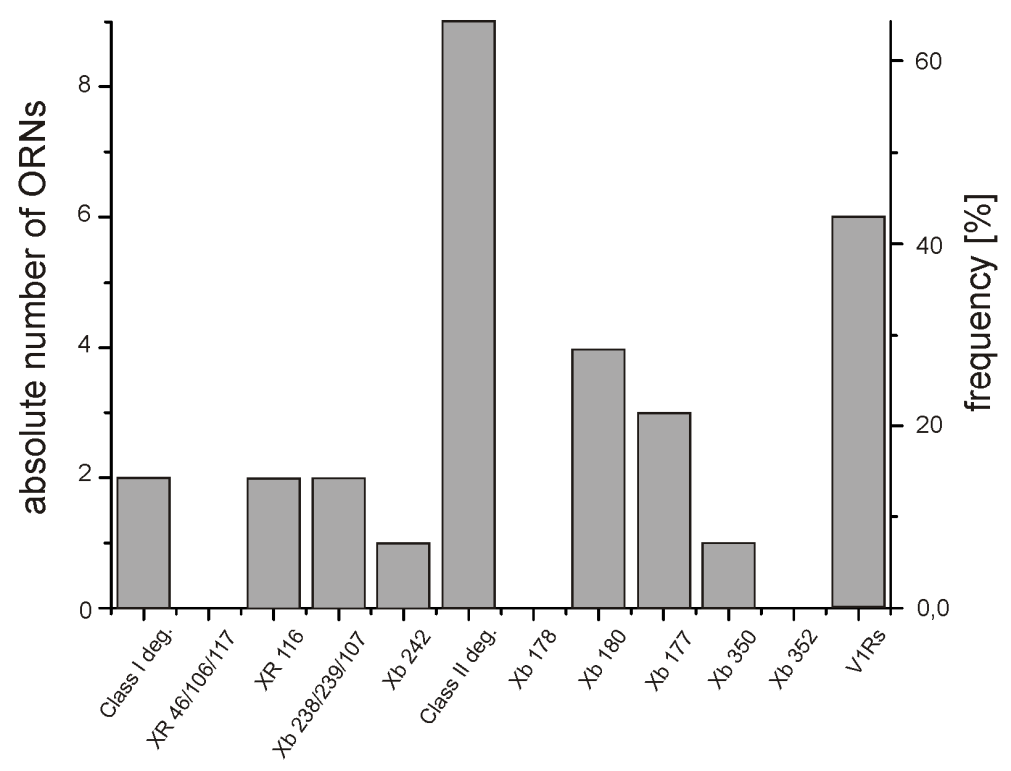

Figure 23: Frequency of OR-expression in preimaged ORNs. The histogram shows for each of the employed primers in how many of the 14 ORNs a PCR product was found. OR-expression in detail: Class I degenerate primers $=14,3 \%$; XR 46/106/117 $=0 \%$; XR $116=14.3 \% ; \mathrm{Xb} 238 / 239 / 107=14.3 \% ; \mathrm{Xb} 242=7.1 \% ;$ Class II degenerate primers $=$ $64.3 \% ; \mathrm{Xb} 178=0 \% ; \mathrm{Xb} 180=28.6 \% ; \mathrm{Xb} 177=21.4 \% ; \mathrm{Xb} 350=7.1 \% ; \mathrm{Xb} 352=0 \%$; $\mathrm{V} 1 \mathrm{Rs}=42.9 \%$. 


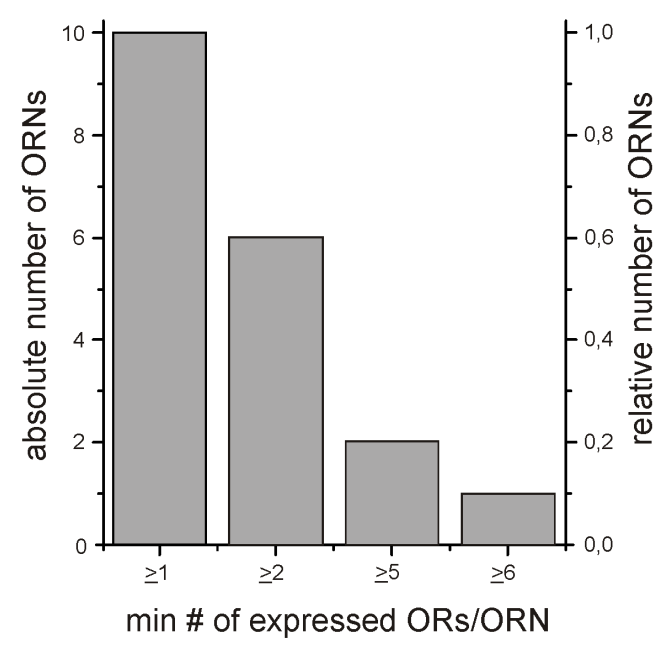

Figure 24: Rate of expressed ORs per preimaged ORN. PCR products of ORs were found in 10 cells $(\mathrm{n}=11$ slices). Six of them expressed at least two receptors. A minimum of five expressed ORs was found in two of these, while one cell expressed at least six receptors.

Representatively for the investigated cells, Figure 25 (A-D) shows the results obtained from a single preimaged ORN (\# 12, Table 5). Time courses of the $\left[\mathrm{Ca}^{2+}\right]_{\mathrm{i}}$ transient upon stimuli application and the PCR products found for this cell are depicted. Application of each single amino acid and of the amino acid mixture elicited $\left[\mathrm{Ca}^{2+}\right]_{\mathrm{i}}$ increases in this olfactory neuron. With regard to receptor expression in this cell, PCR-amplified products were found for $\beta$-actin, the tested class II and I subgroups and for the V1R subgroup. After a subsequent PCR, products were found for five of the tested ORs, namely Xb 180, Xb 177, XR 116, Xb 238/239/107 and Xb 242. Concerning possible contamination derived from gDNA, no PCR product was observed in those samples that had not undergone the reverse transcriptase reaction (Figure 24, E). 
A
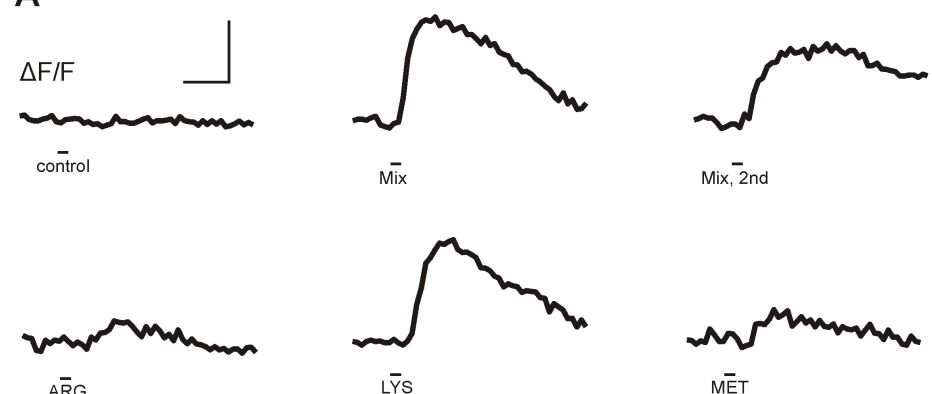

LYs
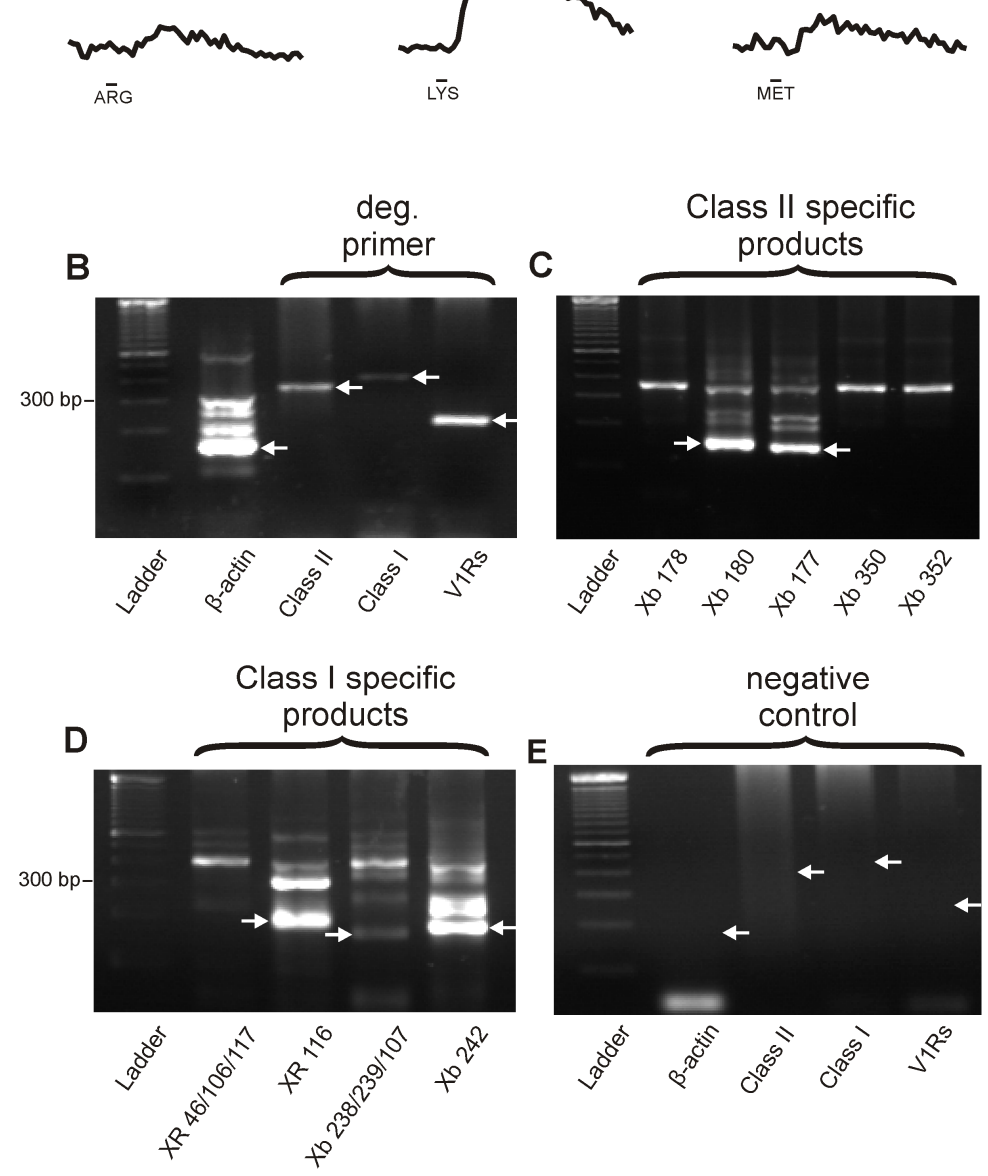

Figure 25: Expression of multiple ORs in a preimaged ORN. (A) Time courses of $\left[\mathrm{Ca}^{2+}\right]_{\mathrm{i}}$ transients of a preimaged ORN (\#12, Table 5). Responses were observed upon application of each single amino acid and for the amino acid mixture, which was applied twice $\left(2^{\text {nd }}\right)$. Application of bath solution as a control showed no comparable response. (B) Single cell RT-PCR of this ORN revealed mRNA of $\beta$-actin, class II ORs, class I ORs and of V1Rs. (C) PCR with specific primers for class II ORs showed expression of Xb 180 and Xb 177, but not of Xb 178, Xb 350 and Xb 352. (D) PCR with specific primers for class I ORs showed expression of XR 116, Xb 238/239/107 and Xb 242 but not of XR 46/106/117. (E) In contrast, no PCR products were obtained from ORNs that had not undergone reverse transcription. Abbreviations: Arg, arginine; Met, methionine; Lys, lysine; Mix, Arg+Met+Lys. Scale bars, $10 \mathrm{~s}$ and $\triangle \mathrm{F} / \mathrm{F} 75 \%$ (A). 


\subsection{Deorphanisation of expressed chemoreceptors}

In order to reconstitute odorant-receptor interactions, the observed physiological responses to each single amino acid were correlated to the expressed receptors. Deorphanisation was thereby based on the following considerations: If one odor molecule can activate multiple ORs, no particular chemoreceptor will always have to be expressed by a cell that responds to this substance. But if a certain ligand Xsensitive receptor is expressed, a response to ligand $\mathrm{X}$ should always be observed. Consequently Table 6 depicts a chemoreceptor/response matrix which gives the response profiles with respect to each of the detected receptors (including degenerate PCR products).

Concerning the two ORNs which expressed class I receptors, it was found that they responded to all three stimuli. While PCR products for XR 116 and $\mathrm{Xb}$ 238/239/107 were found in both cells, the receptor Xb 242 seemed to be expressed in only one of both.

A more differentiated result was obtained with respect to V1 and class II receptors. V1Rs were found to be expressed in six ORNs which responded at least to arginine and/or methionine. Each of the two stimuli initiated responses in five cells, whereas lysine elicited responses in three cells.

With regard to ORNs that expressed class II receptors, it was found that seven out of nine cells responded at least to arginine and/or methionine. The OR Xb 180 was found in four ORNs. Responses upon application of arginine or methionine were observed in three cells respectively, whereas lysine elicited a response in one cell. However, $\mathrm{Xb} 177$ was found in three ORNs which all responded at least to arginine and methionine. One ORN expressed $\mathrm{Xb} 350$ and responded to arginine and methionine.

In summary, the most prominent observations were as follows:

(i) The receptors XR 46/106/117, Xb 178 and Xb 352 were not found to be expressed in amino acid-responsive ORNs.

(ii) ORNs that expressed $\mathrm{Xb} 177$ always responded to arginine and methionine. 
Table 6: Response profiles of expressed chemoreceptors. The table shows a chemoreceptor/response matrix extracted from Table 5. It represents the response profiles of cells with respect to each detected receptor. An "O" indicates a "response" to a particular stimulus; a blank field indicates "no response". Abbreviations: Arg, arginine; Met, methionine; Lys, lysine; Mix, Arg+Met+Lys.

\begin{tabular}{|c|c|c|c|c|c|c|c|c|c|}
\hline Receptor & Arg & Met & Lys & Mix & Receptor & Arg & Met & Lys & Mix \\
\hline Class I deg & & & & & Class II deg & & & & \\
\hline Cell 11 & $\mathrm{O}$ & $\mathrm{O}$ & $\mathrm{O}$ & $\mathrm{O}$ & Cell 1 & & $\mathrm{O}$ & & $\mathrm{O}$ \\
\hline Cell 12 & $\mathrm{O}$ & $\mathrm{O}$ & $\mathrm{O}$ & $\mathrm{O}$ & Cell 2 & $\mathrm{O}$ & & & $\mathrm{O}$ \\
\hline XR 116 & & & & & Cell 4 & $\mathrm{O}$ & & & $\mathrm{O}$ \\
\hline Cell 11 & $\mathrm{O}$ & $\mathrm{O}$ & $\mathrm{O}$ & $\mathrm{O}$ & Cell 6 & $\mathrm{O}$ & $\mathrm{O}$ & & $\mathrm{O}$ \\
\hline Cell 12 & $\mathrm{O}$ & $\mathrm{O}$ & $\mathrm{O}$ & $\mathrm{O}$ & Cell 7 & $\mathrm{O}$ & & & $\mathrm{O}$ \\
\hline $\mathrm{Xb} 238 / 239 / 107$ & & & & & Cell 10 & $\mathrm{O}$ & $\mathrm{O}$ & $\mathrm{O}$ & $\mathrm{O}$ \\
\hline Cell 11 & $\mathrm{O}$ & $\mathrm{O}$ & $\mathrm{O}$ & $\mathrm{O}$ & Cell 11 & $\mathrm{O}$ & $\mathrm{O}$ & $\mathrm{O}$ & $\mathrm{O}$ \\
\hline Cell 12 & $\mathrm{O}$ & $\mathrm{O}$ & $\mathrm{O}$ & $\mathrm{O}$ & Cell 12 & $\mathrm{O}$ & $\mathrm{O}$ & $\mathrm{O}$ & $\mathrm{O}$ \\
\hline $\mathrm{Xb} 242$ & & & & & Cell 13 & & $\mathrm{O}$ & $\mathrm{O}$ & $\mathrm{O}$ \\
\hline Cell 12 & $\mathrm{O}$ & $\mathrm{O}$ & $\mathrm{O}$ & $\mathrm{O}$ & $\mathrm{Xb} 180$ & & & & \\
\hline V1R deg & & & & & Cell 2 & $\mathrm{O}$ & $\mathrm{O}$ & & $\mathrm{O}$ \\
\hline Cell 6 & $\mathrm{O}$ & $\mathrm{O}$ & & $\mathrm{O}$ & Cell 7 & $\mathrm{O}$ & & & $\mathrm{O}$ \\
\hline Cell 7 & $\mathrm{O}$ & & & $\mathrm{O}$ & Cell 12 & $\mathrm{O}$ & $\mathrm{O}$ & $\mathrm{O}$ & $\mathrm{O}$ \\
\hline Cell 8 & $\mathrm{O}$ & $\mathrm{O}$ & & $\mathrm{O}$ & Cell 13 & & $\mathrm{O}$ & $\mathrm{O}$ & $\mathrm{O}$ \\
\hline Cell 11 & $\mathrm{O}$ & $\mathrm{O}$ & $\mathrm{O}$ & $\mathrm{O}$ & $\mathrm{Xb} 177$ & & & & \\
\hline Cell 12 & $\mathrm{O}$ & $\mathrm{O}$ & $\mathrm{O}$ & $\mathrm{O}$ & Cell 2 & $\mathrm{O}$ & $\mathrm{O}$ & & $\mathrm{O}$ \\
\hline \multirow[t]{4}{*}{ Cell 13} & & $\mathrm{O}$ & $\mathrm{O}$ & $\mathrm{O}$ & Cell 6 & $\mathrm{O}$ & $\mathrm{O}$ & & $\mathrm{O}$ \\
\hline & & & & & Cell 12 & $\mathrm{O}$ & $\mathrm{O}$ & $\mathrm{O}$ & $\mathrm{O}$ \\
\hline & & & & & $\mathrm{Xb} 350$ & & & & \\
\hline & & & & & Cell 6 & $\mathrm{O}$ & $\mathrm{O}$ & & $\mathrm{O}$ \\
\hline
\end{tabular}




\section{4}

\section{DISCUSSION}

\subsection{Olfactory receptors}

Accumulated evidence in the past has undoubtedly proven that vertebrate ORNs detect odorant molecules by expression of OR genes (Mombaerts, 1999; Breer, 2003). Discovered in 1991, OR genes have intronless coding regions and encode proteins with seven putative transmembrane helices (Buck and Axel, 1991). Within these proteins, hypervariable regions exist that likely contribute to selective binding of different odorants (Buck and Axel, 1991; Katada et al., 2005). According to genome-wide analysis, it is nowadays assumed that ORs comprise one of the largest, if not the largest, gene family in the genome of many species (Zhang and Firestein, 2002; Niimura and Nei, 2005a,b). Although the great majority of ORNs in the main olfactory epithelium expresses ORs for odor detection, recent studies showed that there are also other kinds of chemoreceptors expressed that are involved in the detection of odorants. These include trace amine-associated receptors (TAARs, Liberles and Buck, 2006; Gliem et al., 2009), receptor guanylyl cyclase GC-D (Leinders-Zufall et al., 2007) and vomeronasal receptors type 1 (V1Rs, Rodriguez and Mombaerts, 2002; Date-Ito et al., 2008).

However, each ORN that is activated by a certain stimulus encodes the odor information and transmits it to glomerula which are the basic units in the odor map of the olfactory bulb. Different spatio-temporal patterns of activated glomerula thereby encode the different odor identities (Wachowiak and Shipley, 2006; Junek et al., 2010). But as there are by far more odorant substances than chemoreceptors, conclusive theories were needed to explain how odorants are generally perceived. A widely accepted hypothesis assumes a combinatorial receptor code for odor detection and incorporates that there is exclusively one OR gene expressed per ORN. The theory thereby based on results of different studies. First, several expression assays revealed that one type of OR can bind several odor molecules and that one odor molecule can activate multiple ORs (Raming et al., 1993; Kiefer et al., 1996; Krautwurst et al., 1998; Speca et al., 1999; Hatt et al., 2001; Kajiya et al., 2001; 
Liberles and Buck, 2006). Second, in situ and single cell RT-PCR studies found only one OR gene expressed per single ORNs (Ressler et al., 1993; Vassar et al., 1993; Malnic et al., 1999; Touhara et al., 1999; Kajiya et al., 2001; Hamana et al., 2003). Furthermore, a negative feedback mechanism by OR proteins themselves was proposed to prevent expression of multiple ORs per single olfactory neuron (Serizawa et al., 2003; Lewcock and Reed, 2004).

But however seductive and plausible this one receptor-one neuron theory may be, several caveats (see section 1.4) do not allow it to be considered proven beyond doubt. As a matter of fact, the one receptor-one neuron theory is difficult to prove as the challenge is to demonstrate not only that one expressed OR gene can be detected per cell but also to ensure that none of the other, often few to many hundred, OR genes are expressed. Therefore it remains a hypothesis, especially since recent studies demonstrated pieces of evidence against it by directly illustrating multiple OR expression in single olfactory neurons (Rawson et al., 2000; Sato et al., 2007; Tian and Ma, 2008).

\subsubsection{How to verify multiple OR gene expression}

In order to find solutions how to substantiate whether single ORNs express one or multiple OR genes simultaneously, past studies and their applied techniques were critically evaluated. One of the main problems for single cell RT-PCR and in situ hybridization was that single ORNs could hardly be tested on the expression of numerous ORs. Since few studies worked with rodents, the lack of many highly conserved regions in their OR genes caused problems designing adequate degenerate primers or in situ probes that cover numerous OR sequences simultaneously (Mombaerts, personal communication). However, these studies employed some degenerate primer pairs (Malnic et al., 1999; Touhara et al., 1999) and degenerate in situ probes (Vassar et al., 1993).

With regard to single cell RT-PCR, it is desirable to solve another apparent obstacle: A relatively high rate of false negative OR-detection. This rate may be explained by insufficient amounts of mRNA isolated or too much digested mRNA respectively. Thus, RT-PCR can only determine the minimum, but not the maximum number of OR genes expressed per ORN (Mombaerts, 2004). 
But despite all substantial technical obstacles, single cell RT-PCR and in situ hybridization are both the most promising techniques to directly test the one receptor-one neuron hypothesis in single ORNs, especially if both techniques were applied in a combined approach. A nested single cell RT-PCR could then be conducted first to find possible coexpressed ORs. Subsequently, probes for in situ hybridization could be created based on the PCR findings. This has two advantages. (i) The efficiency of in situ experiments is increased, which accelerates to (ii) independently verify the results obtained from the PCR experiments.

\subsubsection{Transition to own experiments}

When considering a new study that investigates OR expression in single ORNs, it is also important to realize that the majority of past studies used the olfactory epithelium or single ORNs of adult animals. But what would be the result in olfactory neurons of developing animals? Since the main olfactory system progressively develops, these ORNs may exhibit different features than during adulthood.

A developmental phase of oligogenic OR expression was already proposed in the past (Mombaerts, 2004). This hypothesis incorporates that the low probability of OR gene choice does not necessarily have to be singular in every cell and that oligogenic expression could be governed by a Poisson distribution. It is further speculated that gene choice is followed by positive (for cells expressing one OR) and negative selection (against cells expressing more than one OR) resulting usually in ORNs with only one expressed receptor. ORNs that express multiple OR genes may thereby disappear over time, because there might not be enough of them to form stable glomerula (Ebrahimi and Chess, 2000) or they could be eliminated by activity dependent mechanisms (Mombaerts, 2004; Tian and Ma, 2008). However, if the examined cell population from adults is already shaped by these selective processes, results might not be directly informative regarding the mechanisms of OR gene choice (Mombaerts, 2004). Therefore it was suggested to pay more attention to developing animals and investigate ORNs at a time when they make their OR gene choices. One recent study, which may have followed that advice, investigated the development of OR expression patterns in the olfactory epithelium of the mouse septal organ (Tian and Ma, 2008). Extensive double in situ labeling with combinations of nine mouse OR probes indicated coexpression of any two ORs in single ORNs from stage P0 up to one 
month after birth. The findings confirmed the developmental oligogenic hypothesis as the frequency of coexpression drops from about $2 \%$ to $0.2 \%$ within this month.

Future experiments, which focus on the developing animal, may therefore contribute to revise the one receptor-one neuron theory for vertebrates.

Since our lab works with larval Xenopus laevis and since previous physiological experiments indicated expression and functionality of at least two amino acidresponsive ORs in single ORNs of the tadpoles' OE (Manzini and Schild, 2004; Schild and Manzini, 2004; Gutermann, 2006; Manzini et al., 2007), this animal model seemed to be promising for directly supporting either the developmental oligogenic hypothesis or the one receptor-one neuron theory.

\subsection{Evaluation of the applied method}

Since single cell RT-PCR exhibits the big advantage of testing on multiple ORs simultaneously, this method was selected for this present study. In addition to known olfactory receptors, this study also investigated expression of vomeronasal receptors of type 1 (V1Rs) as it was recently demonstrated that V1R genes are also expressed by ORNs in the main olfactory epithelium of Xenopus (Date-Ito et al., 2008).

However, the technical obstacles of single cell RT-PCR needed to be solved first. These comprised the design of suitable primer pairs and the design of a RT-PCR protocol which considers possible gDNA contamination and amplification from eventually low-expressed receptor transcripts (see section 2.4.1).

\section{Primerdesign}

In order to test on multiple receptor sequences simultaneously degenerate primers were designed for selected ORs and V1Rs based on an alignment of the receptors sequences. The ORs were thereby divided into a class I and class II subgroup.

With respect to sequence homology, several regions within the OR and V1R genes were found that exhibited a high similarity. This observation offered adequate possibilities to design degenerate primers for PCR. In contrast, few variable regions were also found within the OR sequences which enabled the design of specific primers. According to these findings, consecutive nested PCRs could be conducted exhibiting the advantage of detecting even low-expressed receptor transcripts. The possibility of mature ORNs coexpressing one or multiple OR genes at lower levels was thereby already proposed in the past (Mombaerts, 2004). 
Considering the PCR products obtained with degenerate primers, it is noteworthy to mention that these may not only contain amplicons of the investigated chemoreceptors. Degenerate primers may additionally also bind to templates of other, so far unknown receptor sequences as it seems not unlikely that other receptors comprise a similar homology in those coding regions for which the primers were created. The result of a nested PCR could then be that a product is obtained employing degenerate primers but none in a subsequent PCR using specific ones. As such results repeatedly occurred in this study, it was reasoned that the degenerate product was derived from at least one expressed OR gene that was not among the tested ones.

\section{Reverse transcription and cDNA amplification}

Following primer design, a method was developed in order to isolate mRNA material from single ORNs. A patch pipette was employed to collect single ORNs which were either identified electrophysiologically or by calcium-imaging experiments. Subsequently the single cells were expelled into tubes containing diverse agents for reverse transcription (RT). In order to prevent a loss of RNA by RNase-mediate degradation, an RNase inhibitor was added. Reverse transcription was carried out using oligo(dT) primers and a highly sensitive reverse transcriptase (see section 2.4.3). The process was thereby similar to the procedure of previous studies (Matsunami and Buck, 1997; Malnic et al., 1999).

However, after reverse transcription, the probes did not only contain cDNA material but also still the cellular genomic DNA which was a possible contamination factor, eventually leading to false positive results. Initial experiments that directly employed cDNA for PCR produced such false positive data: Using gene specific primers, it was observed that (i) almost each cell seemed to express several of the tested receptors and (ii) that the negative control experiments were occasionally positive (data not shown). Therefore a way had to be found to minimize the risk of creating such contaminating PCR products derived from gDNA. The above mentioned older studies (Matsunami and Buck, 1997; Malnic et al., 1999) approached this problem by a nested PCR, where cDNA, but no gDNA material, was amplified in a first step. Thereby gDNA was diluted prior to a second PCR, where primers were employed which matched conserved regions within the coding sequence of OR genes.

According to this method a similar approach was conducted in the present study. cDNA was amplified using a OR/V1R degenerate forward and an oligo(dT) 
reverse primer. Initially, the degenerate forward primer produced the complement strand of the cDNA. Consequently, both forward and reverse primers could anneal to cDNA material. Since the oligo(dT) primer anneals at the Poly $(A)$ tail of the complementary cDNA strand but not at a gDNA template, just cDNAs of olfactory and vomeronasal receptors will be amplified. As it was shown that the 3'-untranslated region of mRNA transcripts generally differ in length and contain about 400 base pairs on average for cold-blooded vertebrates (Mazumder et al., 2003), the elongation time of the cDNA amplification protocol was set to 3 min. This ensured amplification of cDNA strands (including $3^{6}$-UTR and Poly(T) tail) with a length of up to a few thousand basepairs and thereby considered the possibility of $3^{6}$-UTRs of OR/V1R transcripts being longer than the estimated mean value. These considerations were also taken into account at previous single cell PCR studies working with warmblooded vertebrates, where the elongation time was set between 2 (Touhara et al., 1999) and 6 min (Dulac and Axel, 1995; Matsunami and Buck, 1997; Malnic et al., 1999).

However, if an aliquot of this first PCR reaction is now taken and employed in a subsequent PCR where primers theoretically also match regions of gDNA, the gDNA will have to be diluted twice before contaminating PCR products could be sufficiently produced in a PCR reaction.

In order to calculate this dilution factor, it was assumed that the chromosomes of the gDNA were randomly distributed after cDNA synthesis as the temperature protocol of the RT makes degradation of the nuclear envelope probable. With regard to the first PCR, where only cDNA is amplified, the initial solution was diluted by 4:46. The aliquot that was then used for the second PCR was also diluted by 4:46. In total, the aliquot of the initial cDNA/gDNA-containing solution was diluted by 1:132. This dilution factor seemed to be sufficient to minimize the risk of gDNA contamination, as no PCR products were obtained in the negative control experiments. In addition, the observation of an occasional and unequal distribution of receptor expression (see Figure 19 and 23) further suggest a reliable result of the single cell RT-PCR experiments, especially compared to the initial results where false positive results for receptor expression were probably found in the majority of the investigated cells.

However, an ideal single cell RT-PCR approach would involve a DNase digestion prior to cDNA synthesis. By this, results would be most conclusive. A previous study pursued that strategy and eliminated gDNA of single cells by a DNase-mediated digestion step on a RNA isolation spin cartridge (Touhara et al., 
1999). Unfortunately, the cartridge production was finally stopped when the company (GIBCO-BRL) was overtaken by Invitrogen in the year 2000. Nontheless, a DNase digestion step was also tried to be incorporated in the RT-protocol of this study. But when gDNA was aimed to be eliminated, the modified RT-protocol failed to succeed (data not shown). As the reverse transcriptase is a highly sensitive enzyme with requires its own buffer system, the addition of a DNase with another buffer system, probably caused inefficiency of the enzyme.

In summary, the developed method for detecting expression of OR/V1Rs in single ORNs of larval Xenopus led to (i) the possibility of detecting even lowexpressed chemoreceptor transcripts and (ii) a minimization of contaminating PCR products derived from gDNA.

\subsection{Olfactory and vomeronasal receptors are expressed in larval olfactory tissue}

After the primers and the RT-PCR protocol were successfully designed, it was verified which of the investigated chemoreceptors are expressed during the investigated larval stages of the animal. With regard to OR gene expression in Xenopus laevis, an earlier study demonstrated that expression of class I ORs is initiated quite early in development (stage 32) whereas classes II ORs were found from stage 49 onwards (Mezler et al., 2001).

According to these findings it seemed probable to detect some of the selected ORs (see section 2.4.1) in animals of the investigated larval stages (52-54). In addition to ORs, gene expression of V1Rs was also investigated in this study. A recent study characterized the expression of these receptors exclusively in adult animals of Xenopus (Date-Ito et al., 2008), which motivated to examine expression in ORNs of tadpoles. As $2 / 3$ of all V1R-positive ORNs were shown to express one out of just four V1Rs, these four were selected and investigated in this study.

In order to show expression of the selected ORs and V1Rs and find candidate genes for the upcoming single cell RT-PCR, the mRNA content of the olfactory organ was analyzed. cDNA was synthesized and tested with degenerate and specific primers in a nested PCR protocol (see section 2.4.2). Surprisingly, the results revealed that all designed primers produced a positive result. The specificity of the PCR products and thereby the specificity of the primers were confirmed by sequencing of the specific PCR products. Since this finding was validated by two independent methods (Trizol 
method and RNeasy Mini Kit) which both incorporated a DNase digestion step in the experimental protocol, it seems probable that tadpoles of the investigated stages indeed express the found receptors.

However, as it was only possible to generate "overlapping" primers for $\mathrm{Xb}$ 238/239/107, XR 46/106/117 and V1R10/11/12/23, it can not be reliably stated whether each of these embedded receptors was contained in the PCR product. This especially accounts for Xb 238/239/107 where sequencing revealed expression of only $\mathrm{Xb} 238$. With regard to the other PCR products it can only be stated, that at least one of the embedded receptors is expressed, but not which.

With respect to the expression of vomeronasal receptors in Xenopus, the general results of the expression assay demonstrated that V1Rs seem to be already expressed during the larval stages. Concerning the sequence alignment (see Supplementary figure 3) between the four database X.t. nucleotide sequences and the PCR product of X.1., the identity was found to be around $90 \%$. This is consistent with the finding of a previous study which showed that the sequence identity of another kind of chemoreceptors, namely trace amine-associated receptors, is around $94 \%$ between both species (Gliem et al., 2009).

In summary, this expression assay revealed that almost each of the tested chemoreceptors is expressed in the olfactory tissue during the investigated stages. It was shown for the first time that V1 receptor genes are expressed in the olfactory organ of larval Xenopus. Furthermore, the observed specificity of the primers implicated that they were also suitable for the upcoming single cell RT-PCR.

\subsection{Multiple receptors are expressed in single ORNs}

After the expression of OR and V1R genes was verified in the olfactory tissue, a single cell RT-PCR was conducted to validate whether single or multiple chemoreceptors are expressed in ORNs of larval animals. mRNA was thereby collected from single ORNs in two different sets of experiments which were patch-clamp measurements or calcium-imaging experiments respectively. Subsequently, mRNA was subjected to the above mentioned double nested RT-PCR.

The general outcome of both sets of experiements was quite striking. Out of 78 ORNs that were collected in total and subjected to reverse transcription, coexpression of at least two OR/V1R genes was found in about 18\% (=14 ORNs). In 33\% (=26 ORNs) expression of at least one receptor gene was validated. The specificity of the PCR products and the respective primers was reconfirmed by direct sequencing, 
which was successfully conducted for 9 tested PCR products (partly shown in Supplementary figure 4). Secondary to the specific products, additional bands were occasionally obtained in the agarose gel. One usually originated from the degenerate PCR product itself, while the others were probably created according to the long amplification process in three successive PCRs.

With respect to the efficiency of chemoreceptor detection, the above mentioned result $(33 \%)$ is in agreement with the results of ealier single cell RT-PCR studies, where OR genes were reported to be detected in 30-50\% of all investigated cells (Malnic et al., 1999; Hamana et al., 2003; Mombaerts, 2004).

In detail for this study, the success rate for chemoreceptor detection was 16/44 in experiments, where ORNs were chosen without any knowledge of their ligand spectrum. In contrast, when amino acid-responsive ORNs were examined after calcium-imaging experiments, the success rate was 10/34. The rate for preimaged ORNs was thereby comparable to those of previous studies. One group found PCRproducts in 14 out of 47 responsive ORNs, while the success rate was 18/26 in ORNs that did not respond to applied odors (Malnic et al., 1999). A more recent study obtained a success rate of 28/103 for preimaged and responsive ORNs and a ratio of $5 / 6$ with no calcium-imaging assay (Hamana et al., 2003). In addition to the accordance regarding the rates of preimaged ORNs, another observation could be deduced from the comparison between the success rates. All studies obtained a decrease in their success rate when they investigated only odorant-responsive ORNs, which was most probably due to the bias of the selected cells. The decrease was more significant for the studies of Hamana et al. (56.1\%) and Malnic et al. (29.6\%), whereas the difference was about $10 \%$ in this study (considering only PCR-products derived from those primer pairs that were used in both sets of experiments). The reasons for this divergence may be of variable origins. Both previous studies used ORNs of adult mice, whereas this study used ORNs of larval Xenopus. Mice ORNs were first dissociated from the epithelium and then selected if they were responsive to aliphatic alcohols and acids (Malnic et al., 1999) as well as to enantiomeric carvone (Hamana et al., 2003). This study used acute tissue slices and selected ORNs that responded to amino acids. With regard to dissociated cells it is noteworthy to mention that some functions of ORNs, e.g. odor sensitivity, may get impaired if the cells are not anymore embedded in their epithelial assembly (Breunig et al., 2010). In addition to these observations, the bias of the primers may have unintentionally contributed to the obtained findings as the success rate also depends on (i) the number of sequence 
templates which are matched by the primers and on (ii) the amount of receptors among these that are sensitive to the applied odorants.

However, if the mechanism of OR gene expression is different between larval and adult animals (Mombaerts, 2004) and if multiple ORs are expressed in ORNs of larval animals, the success rates between both groups of selected cells will anyway not vary greatly with respect to larval animals. A preconditions is of course that the applied primers cover multiple sequences simultaneously.

In summary, this study demonstrated that a subset of ORNs exists in the OE of larval Xenopus, which expresses two or more chemoreceptors simultaneously. With regard to amino acid-responsive cells, the results confirm suggestions of previous studies done in our lab (Manzini and Schild, 2004; Schild and Manzini, 2004; Gutermann, 2006; Manzini et al., 2007). Cross-adaptation experiments conclusively demonstrated that a subset of amino acid-responsive ORNs exists which expresses at least two functional amino acid-sensitive receptors simultaneously (Gutermann, 2006). In addition, the present study approves a previously stated model of a developmental phase of oligogenic OR expression in the olfactory organ (Mombaerts, 2004). It supports the consideration of larval animals being promising candidates to satisfactorily test this hypothesis (Mombaerts, 2004) and confirms recent findings observed in new-born mice (Tian and Ma, 2008). However, the presented data of this thesis are still consistent with the body of literature and do not disprove a one receptor-one neuron hypothesis for ORNs in adult animals. But they may contribute to shift the focus from a rather dogmatic understanding of OR-expression to a more dynamic view of the olfactory epithelium.

Accordingly, Figure 26 illustrates how OR-expression could be accomplished in Xenopus. The olfactory epithelium of larval animals thereby contains a subset of ORNs expressing multiple ORs. On the contrary this subset is hypothesized to be eliminated in adults. 
larval stage
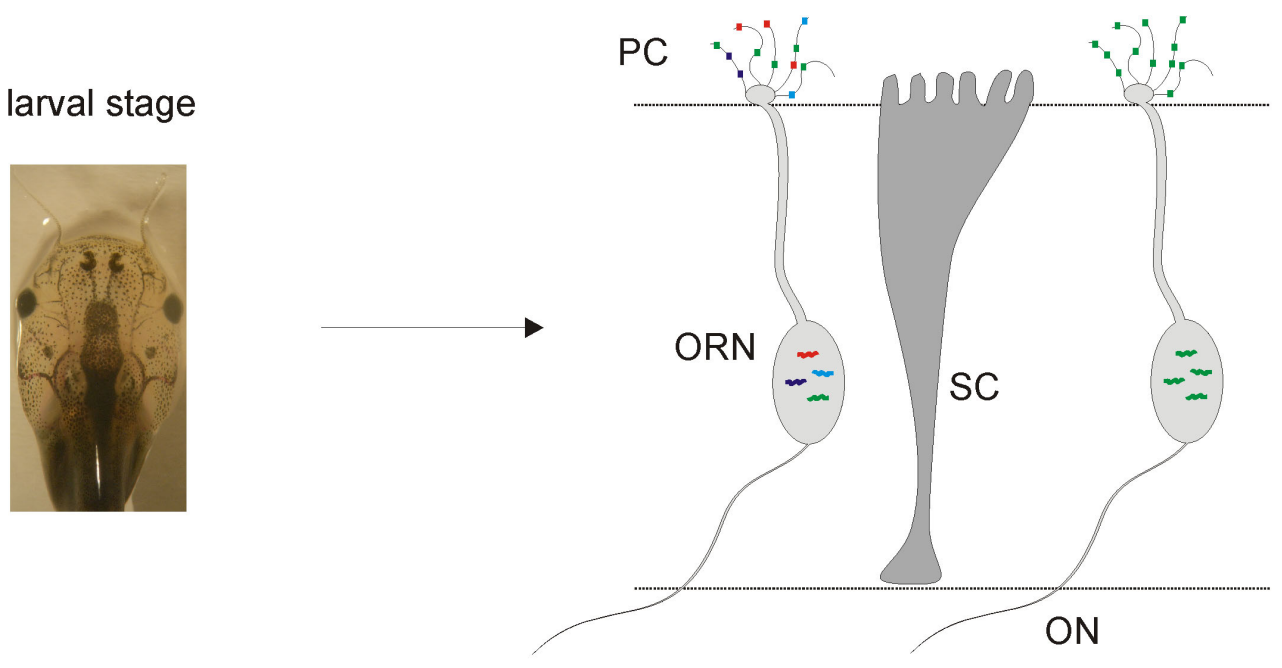

adult stage
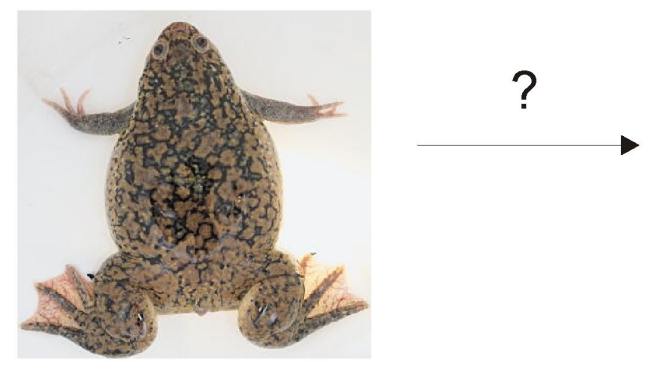

Figure 26: Model of an oligogenic OR expression during the developmental phase of Xenopus laevis. This schematic respresentation illustrates a subset of ORNs in larval Xenopus that express multiple kinds of functional ORs simultaneously. On the contrary, it is proposed, although not proven yet, that ORNs of adult animals express only one kind of receptor. Abbreviation: SC, sustentacular cell; PC, principal cavity; ON, olfactory nerve. The image of the adult frog was modified after Freeze et al., 2009. 


\subsection{Deorphanisation of chemoreceptors}

In order to identify whether one of the expressed chemoreceptors is sensitive to the applied amino acids, the expressed receptors were correlated to the observed response patterns of those responsive ORNs which were found to express the respective receptors. The recognition profiles led to some concluding remarks about ligandsensitivities of the investigated receptors.

With regard to the investigated class I receptors, not much can be interpreted about their sensitivities as class I OR expression was just observed in two ORNs, which both responded to all three odorant stimuli (arginine, methionine, lysine). But as one of both cells did not express the OR Xb 242, it may be stated that this receptor is not solely, if at all, necessary for the detection of one of the three amino acids. Regarding the other expressed class I receptors, no further conclusions can be drawn about their ligand-sensitivities, especially as class II and V1 receptors were also found to be expressed in these cells. With respect to the class I OR Xb 107, a previous study demonstrated in a heterologous cell expression assay that this receptor responds to a mixture of long-chain neutral amino acids (proline, valine, leucine, isoleucine, methionine) but not to short-chain neutral amino acids (glycine, alanine, serine, threonine, cysteine) and basic amino acids (arginine, lysine, histidine) (Mezler et al., 2001). However, as this receptor does not seem to be expressed during the investigated larval stages (see Supplementary figure 1) the present study was not able to confirm the above mentioned findings.

With regard to class II ORs, specific PCR products of three receptors were found. Xb 180 was thereby expressed in four ORNs. But since their response profiles were not congruent, the receptor $\mathrm{Xb} 180$ may not be considered to either detect arginine, methionine or lysine. On the contrary, the receptor Xb 177 was found in three ORNs which always responded to arginine and methionine. Therefore Xb 177 can be considered as a candidate receptor being sensitive to arginine and/or methionine. In addition to the already mentioned class II receptors, Xb 350 was once found to be expressed by an ORN that responded to arginine and methionine. But as this cell also expressed Xb 177 and V1Rs, no conclusive argument would speak in favor of or against the hypothesis that this receptor is sensitive to both amino acids.

Furthermore, deorphanisation yielded a final observation with regard to ORNs expressing degenerate class II or V1 receptor PCR products: Each cell responded to arginine and/or methionine. One might therefore speculate whether class II and V1R products regularly contain sequences from receptors that are sensitive to the amino 
acids arginine and/or methionine. As the degenerate primers may cover multiple receptor sequences simultaneously, the proposed option would be feasible.

Taken together, the deorphanisation study demonstrated an approach for the functional identification of chemoreceptors from single ORNs. It was concluded that the class II OR Xb 177 can be considered as a promising candidate receptor that is sensitive to arginine and/or methionine, whereas Xb 180 was suggested not to detect one of the tested amino acids. In addition, the obtained data suggested a hypothesis that if ORNs express certain class II ORs and/or V1Rs, the respective cells will always respond to arginine and/or methionine. However, the presented results should be seen as preliminary. A higher number of e.g. Xb 177-expressing ORNs is desirable to convincingly claim knowledge about the receptors ligand-sensitivities.

\subsection{Future experiments}

The reported observations motivate a number of future experiments that are partly planned already:

- To improve the success rate for OR-detection, all 410 previously proposed functional OR sequences of Xenopus (Niimura and Nei, 2005a) may be extracted from the database and investigated in an accurate alignment. The results could eventually lead to the generation of new primer combinations which match template sites of more receptor sequences. This would be beneficial (i) for an extension of the OR-expression assay and (ii) for future deorphanisation studies.

- In order to (i) validate results of the OE-expression assay and (ii) show in which parts of the olfactory epithelium the investigated chemoreceptors are preferentially expressed, in situ experiments could be conducted. With regard to V1 receptors, in situ experiments could help to characterize the expression of all 21 putatively functional receptors, which would certainly become a project of its own.

- A confirmation of the presented single cell RT-PCR results is desirable. The finding of some ORNs expressing multiple chemoreceptors simultaneously 
needs to be independently verified, especially as the one receptor-one neuron hypothesis elevated to the status of a rule or even of a dogma for ORexpression in vertebrates.

a. Double or eventually multiple labeling in situ experiments could directly and, in particular, independently prove the results obtained by single cell RT-PCR.

b. Physiological experiments, such as cross-adaptation data (Gutermann, 2006) or studies investigating odor antagonism (Oka et al., 2004), already produced supportive arguments for an oligogenic OR expression, even with regard to the functionality of simultaneously expressed receptors. The latter information is thereby quite valuable as no reliable and specific antibodies or aptamers are available to detect olfactory receptor proteins so far. Although some cross-adaptation data was already produced in the past, the number of trials eventually needs to be increased.

- In addition to the validation of single cell RT-PCR results, multiple labeling in situ experiments would also allow to examine the total epithelial proportion of ORNs coexpressing chemoreceptors.

- In order to verify whether ORNs of adult animals exclusively express one kind of chemoreceptor per cell, in situ experiments would be the most efficient ones to choose

- To validate the above mentioned data on ligand-sensitivities of Xb 177 and class II/V1R expressing ORNs, a higher number of experiments is desirable in order to substantiate the preliminary results.

- In order to gain more knowledge about the ligand-sensitivities of the expressed receptors, a more elaborated application system may be employed to test on more odorants during one experiment. 


\section{5 \\ SUMMARY}

This thesis aimed at investigating gene expression of odorant receptors in olfactory receptor neurons of larval Xenopus. Odorant receptors are ciliary proteins and located in the mucus layer of the olfactory epithelium. Their main task is to detect odorants and contribute to the transduction of odorant information. In vertebrates, gene expression of these proteins was assumed to follow the widely accepted rule of a one receptor-one neuron hypothesis. According to this theory and observations that one kind of receptor can detect multiple odorant molecules, a combinatorial code for odor detection was proposed to explain peripheral coding of olfactory stimuli. But since a few studies found or suggested ORNs coexpressing olfactory receptors, the one receptor-one neuron hypothesis was begun to be critically revised, which eventually resulted in the hypothesis of a developmental phase of oligogenic receptor expression. This theory assumes that ORNs can express two or more olfactory receptors during the developing phase of the olfactory organ. To date only three studies have obtained evidence speaking against the dogma of a one receptor-one neuron hypothesis. Out of these, just one obtained results that speak in favor of the above mentioned alternative theory. This motivated to examine OR-expression in larval Xenopus and validate whether an oligogenic expression of ORs can be observed in ORNs of this species.

First, known olfactory receptors of Xenopus were searched in databases to enable the design of degenerate and specific primers for a nested RT-PCR approach. Subsequently, these receptors were examined on their expression in the olfactory tissue. Almost each of the tested receptors was thereby found to be expressed in animals of the investigated larval stages. Vomeronasal receptors of type 1, which were recently reported to be expressed in ORNs of adult Xenopus, were additionally tested and were shown for the first time to be expressed in the olfactory tissue of tadpoles.

Following this expression assay, a double-nested single cell RT-PCR protocol was developed to analyze receptor-expression in single ORNs. The crucial point was thereby to simultaneously amplify cDNA and dilute any traces of gDNA. By this, the risk of contaminating PCR products, derived by gDNA, was minimized.

Subsequently single ORNs were identified and collected either after patch-clamp measurements or calcium-imaging experiments. In total, 78 cells were harvested and 
subjected to reverse transcription, whereas 22 were used as negative controls. The result of the RT-PCRs revealed a subset of ORNs that express two or multiple chemoreceptors simultaneously. This finding thus approves the hypothesis of an oligogenic expression in developing animals and confirms recent data obtained from new-born mice.

In addition, this study demonstrated a method to functionally identify chemoreceptors from single olfactory neurons, using a combined experimental approach that included calcium-imaging and single cell RT-PCR. Following the application of three amino acids as olfactory stimuli, the responsive ORNs were harvested and examined on their receptor expression. The expressed receptors were then correlated to the observed response patterns of the respective cells. It was reasoned that if a certain receptor is expressed and sensitive to the applied odorants, every ORN that showed expression of that receptor will have always responded to the applied substance(s). With regard to the investigated receptors of this study, the class II OR Xb 177 was found to be a promising candidate receptor for the detection of arginine and/or methionine, whereas $\mathrm{Xb} 180$ was suggested not to detect one of the tested amino acids. In addition, the obtained data suggested the hypothesis that if ORNs express certain class II ORs and/or V1Rs, the respective cells will always respond to arginine and/or methionine. Although the result should be regarded as preliminary, the method turned out to be a promising tool for agonist-directed screening of chemoreceptors in olfactory neurons of larval Xenopus. 


\section{REFERENCES}

Abaffy T, Malhotra A and Luetje CW (2007) The molecular basis for ligand specificity in a mouse olfactory receptor: a network of functionally important residues. J Biol Chem 282:1216-1224.

Altner H (1962). Untersuchungen über Leistungen und Bau der Nase des südafrikanischen Krallenfrosches Xenopus laevis (Daudin, 1803). J Comp Physiol A Neuroethol Sens Neural Behav Physiol 45:272-306

Avila VL and Frye PG (1978) Feeding behavior of the African Clawed frog (Xenopus laevis Daudin): effect of prey type. J Herpetol 12:391-396.

Barth AL, Justice NJ and Ngai J (1996) Asynchronous onset of odorant receptor expression in the developing zebrafish olfactory system. Neuron 16:23-34.

Berkowicz DA, Trombley PQ and Shepherd GM (1994) Evidence for glutamate as the olfactory receptor cell neurotransmitter. J Neurophysiol 71:2557-2561.

Boekhoff I and Breer H (1992) Termination of second messenger signaling in olfaction. Proc Natl Acad Sci U S A 89:471-474.

Boekhoff I, Schleicher S, Strotmann J and Breer H (1992) Odor-induced phosphorylation of olfactory cilia proteins. Proc Natl Acad Sci U S A 89:1198311987.

Boekhoff I, Michel WC, Breer H and Ache BW (1994) Single odors differentially stimulate dual second messenger pathways in lobster olfactory receptor cells. $J$ Neurosci 14:3304-3309.

Borisy FF, Ronnett GV, Cunningham AM, Juilfs D, Beavo J and Snyder SH (1992) Calcium/calmodulin-activated phosphodiesterase expressed in olfactory receptor neurons. J Neurosci 12:915-923.

Bozza T, Feinstein P, Zheng C and Mombaerts P (2002) Odorant receptor expression defines functional units in the mouse olfactory system. J Neurosci 22:3033-3043.

Bozza T, Vassalli A, Fuss S, Zhang JJ, Weiland B, Pacifico R, Feinstein P and Mombaerts P. (2009) Mapping of class I and class II odorant receptors to glomerular domains by two distinct types of olfactory sensory neurons in the mouse. Neuron 61:220-233. 
Bradley J, Bönigk W, Yau KW and Frings S (2004) Calmodulin permanently associates with rat olfactory CNG channels under native conditions. Nat Neurosci 7:705-710.

Breer H and Shepherd GM (1993) Implications of the NO/cGMP system for olfaction. Trends Neurosci 16:5-9.

Breer H (2003) Olfactory receptors: molecular basis for recognition and discrimination of odors. Anal Bioanal Chem 377:427-433.

Breipohl W, Laugwitz HJ and Bornfeld N (1974) Topological relations between the dendrites of olfactory sensory cells and sustentacular cells in different vertebrates. An ultrastructural study. J Anat 117:89-94.

Brennan PA (2001) The vomeronasal system. Cell Mol Life Sci 58:546-555.

Breunig E, Manzini I, Piscitelli F, Gutermann B, Di Marzo V, Schild D and Czesnik D (2010) The endocannabinoid 2-arachidonoyl-glycerol controls odor sensitivity in larvae of Xenopus laevis J Neurosci 30:8965-8973.

Broillet MC and Firestein S (1996) Gaseous second messengers in vertebrate olfaction. J Neurobiol 30:49-57.

Bruch RC (1996) Phosphoinositide second messengers in olfaction. Comp Biochem Physiol B Biochem Mol Biol 113:451-459.

Buck L and Axel R (1991) A novel multigene family may encode odorant receptors: a molecular basis for odor recognition. Cell 65:175-187.

Buck LB (2004) Olfactory receptors and odor coding in mammals. Nutr Rev 62:S184188.

Byrd CA and Burd GD (1991) Development of the olfactory bulb in the clawed frog, Xenopus laevis: amorphological and quantitative analysis. J Comp Neurol 314:7990.

Caprio J and Byrd RP Jr (1984) Electrophysiological evidence for acidic, basic, and neutral amino acid olfactory receptor sites in the catfish. J Gen Physiol 84:403-422.

Chen TY and Yau KW (1994) Direct modulation by $\mathrm{Ca}^{2+}$-calmodulin of cyclic nucleotide-activated channel of rat olfactory receptor neurons. Nature 368:545-548.

Chen S, Lane AP, Bock R, Leinders-Zufall T and Zufall F (2000) Blocking adenylyl cyclase inhibits olfactory generator currents induced by "IP(3)-odors". $J$ Neurophysiol 84:575-580. 
Chess A, Simon I, Cedar H and Axel R (1994) Allelic inactivation regulates olfactory receptor gene expression. Cell 78:823-834.

Date-Ito A, Ohara H, Ichikawa M, Mori Y and Hagino-Yamagishi K (2008) Xenopus V1R vomeronasal receptor family is expressed in the main olfactory system. Chem Senses 33:339-346.

Dawson TM, Arriza JL, Jaworsky DE, Borisy FF, Attramadal H, Lefkowitz RJ and Ronnett GV (1993) Beta-adrenergic receptor kinase-2 and beta-arrestin-2 as mediators of odorant-induced desensitization. Science 259:825-829.

Dhallan RS, Yau KW, Schrader KA and Reed RR (1990) Primary structure and functional expression of a cyclic nucleotide-activated channel from olfactory neurons. Nature 347:184-187.

Doty RL (2008) The olfactory vector hypothesis of neurodegenerative disease: is it viable? Ann Neurol 63:7-15.

Doty RL (2009) The olfactory system and its disorders. Semin Neurol 29:74-81.

Dulac C and Axel R (1995) A novel family of genes encoding putative pheromone receptors in mammals. Cell 83:195-206.

Ebrahimi FA and Chess A (2000) Olfactory neurons are interdependent in maintaining axonal projections. Curr Biol 10:219-222.

Fadool DA and Ache BW (1992) Plasma membrane inositol 1,4,5-trisphosphateactivated channels mediate signal transduction in lobster olfactory receptor neurons. Neuron 9:907-918.

Feinstein P and Mombaerts P (2004) A contextual model for axonal sorting into glomeruli in the mouse olfactory system. Cell 117:817-831.

Feinstein P, Bozza T, Rodriguez I, Vassalli A and Mombaerts P (2004) Axon guidance of mouse olfactory sensory neurons by odorant receptors and the beta2 adrenergic receptor. Cell 117:833-846.

Firestein S, Darrow B and Shepherd GM. (1991) Activation of the sensory current in salamander olfactory receptor neurons depends on a $G$ protein-mediated cAMP second messenger system. Neuron 6:825-835.

Firestein S, Picco C and Menini A (1993) The relation between stimulus and response in olfactory receptor cells of the tiger salamander. J Physiol 468:1-10. 
Firestein S and Shepherd GM (1995) Interaction of anionic and cationic currents leads to a voltage dependence in the odor response of olfactory receptor neurons. $J$ Neurophysiol 73:562-567.

Firestein S (2001) How the olfactory system makes sense of scents. Nature 413:211218.

Firestein S (2004) A code in the nose. Sci STKE 227:pe15.

Fleischmann A, Shykind BM, Sosulski DL, Franks KM, Glinka ME, Mei DF, Sun Y, Kirkland J, Mendelsohn M, Albers MW and Axel R (2008) Mice with a "monoclonal nose": perturbations in an olfactory map impair odor discrimination. Neuron 60:1068-1081.

Freitag J, Krieger J, Strotmann J and Breer H (1995) Two classes of olfactory receptors in Xenopus laevis. Neuron 15:1383-1392.

Freitag J, Ludwig G, Andreini I, Rössler P and Breer H (1998) Olfactory receptors in aquatic and terrestrial vertebrates. J Comp Physiol A 183: 635-650.

Freeze HH, Vacquier VD and Esko JD (2009) Deuterostomes. Essentials of Glycobiology. 2nd edition. Cold Spring Harbor (NY): Cold Spring Harbor Laboratory Press; Chapter 25.

Frings S, Lynch JW and Lindemann B (1992) Properties of cyclic nucleotide-gated channels mediating olfactory transduction. Activation, selectivity, and blockage. $J$ Gen Physiol 100:45-67.

Fülle HJ, Vassar R, Foster DC, Yang RB, Axel R and Garbers DL (1995) A receptor guanylyl cyclase expressed specifically in olfactory sensory neurons. Proc Natl Acad Sci U S 92:3571-3575.

Fuss SH and Ray A (2009) Mechanisms of odorant receptor gene choice in Drosophila and vertebrates. Mol Cell Neurosci 41:101-112.

Gaudin A and Gascuel J (2005) 3D atlas describing the ontogenic evolution of the primary olfactory projections in the olfactory bulb of Xenopus laevis. J Comp Neurol 489:403-424.

Getchell ML and Getchell TV (1992) Fine structural aspects of secretion and extrinsic innervation in the olfactory mucosa. Microsc Res Tech 23:111-127.

Getchell TV (1986) Functional properties of vertebrate olfactory receptor neurons. Physiol Rev 66:772-818. 
Gliem S, Schild D and Manzini I (2009) Highly specific responses to amine odorants of individual olfactory receptor neurons in situ. Eur J Neurosci 29:2315-2326.

Glusman G, Bahar A, Sharon D, Pilpel Y, White J and Lancet D (2000) The olfactory receptor gene superfamily: data mining, classification, and nomenclature. Mamm Genome 11:1016-1023.

Glusman G, Yanai I, Rubin I and Lancet D (2001) The complete human olfactory subgenome. Genome Res 11:685-702.

Godfrey PA, Malnic B and Buck LB (2004) The mouse olfactory receptor gene family. Proc Natl Acad Sci U S A 101:2156-2161.

Gold GH (1999) Controversial issues in vertebrate olfactory transduction. Annu Rev Physiol 61:857-871.

Grosmaitre X, Vassalli A, Mombaerts P, Shepherd GM and Ma M (2006) Odorant responses of olfactory sensory neurons expressing the odorant receptor MOR23: a patch clamp analysis in gene-targeted mice. Proc Nat1 Acad Sci U S A 103:19701975.

Gutermann B (2006) Charakterisierung spezifischer Duftstoffantworten olfaktorischer Rezeptorneurone von Xenopus-laevis-Larven (doctoral dissertation).

Halpern M (1987) The organization and function of the vomeronasal system. Annu Rev Neurosci 10:325-362.

Hagino-Yamagishi K, Moriya K, Kubo H, Wakabayashi Y, Isobe N, Saito S, Ichikawa $\mathrm{M}$ and Yazaki K (2004) Expression of vomeronasal receptor genes in Xenopus laevis. J Comp Neurol 472:246-256.

Hamana H, Hirono J, Kizumi M and Sato T (2003) Sensitivity-dependent hierarchical receptor codes for odors Chem Senses 28:87-104.

Hamill OP, Marty A, Neher E, Sakmann B and Sigworth FJ (1981) Improved patchclamp techniques for high-resolution current recording from cells and cell-free membrane patches. Pflugers Arch 391:85-100.

Hansen A, Reiss J, Gentry C and Burd G (1998) Ultrastructure of the Olfactory Organ in the Clawed Frog, Xenopus laevis, During Larval Development and Metamorphosis. J Comp Neurol 398:273-288. 
Hassenklöver T, Kurtanska S, Bartoszek I, Junek S, Schild D and Manzini I (2008) Nucleotide-induced $\mathrm{Ca}^{2+}$ signaling in sustentacular supporting cells of the olfactory epithelium. Glia 56:1614-1624.

Hassenklöver T, Schwartz P, Schild D and Manzini I (2009) Purinergic Signaling Regulates Cell Proliferation of Olfactory Epithelium Progenitors. Stem Cells 27:2022-2031.

Hatt H, Lang K and Gisselmann G (2001) Functional expression and characterization of odorant receptors using the Semliki Forest virus system. Biol Chem 382:12071214

Hegg CC and Lucero MT (2006) Purinergic receptor antagonists inhibit odorantinduced heat shock protein 25 induction in mouse olfactory epithelium. Glia 53:182-190.

Iida A and Kashiwayanagi M (1999) Responses of Xenopus laevis water nose to water-soluble and volatile odorants. J Gen Physiol 114:85-92.

Imanaka Y and Takeuchi H (2001) Spiking properties of olfactory receptor cells in the slice preparation. Chem Senses 26:1023-1027.

Ishii T, Serizawa S, Kohda A, Nakatani H, Shiroishi T, Okumura K, Iwakura Y, Nagawa F, Tsuboi A and Sakano H (2001) Monoallelic expression of the odourant receptor gene and axonal projection of olfactory sensory neurones. Genes Cells 6:71-78.

Ivic L, Pyrski MM, Margolis JW, Richards LJ, Firestein S and Margolis FL (2000) Adenoviral vector-mediated rescue of the OMP-null phenotype in vivo. Nat Neurosci 3:1113-1120.

Iwema CL, Fang H, Kurtz DB, Youngentob SL and Schwob JE (2004) Odorant receptor expression patterns are restored in lesion-recovered rat olfactory epithelium. J Neurosci 24:356-369.

Jia C, Doherty JP, Crudgington S and Hegg CC (2009) Activation of purinergic receptors induces proliferation and neuronal differentiation in Swiss Webster mouse olfactory epithelium. Neuroscience 163:120-128.

Jia C and Hegg CC (2010) NPY mediates ATP-induced neuroproliferation in adult mouse olfactory epithelium. Neurobiol Dis. 38:405-413. 
Jones DT and Reed RR (1989) Golf: an olfactory neuron specific-G protein involved in odorant signal transduction. Science 244:790-795.

Juilfs DM, Fülle HJ, Zhao AZ, Houslay MD, Garbers DL and Beavo JA (1997) A subset of olfactory neurons that selectively express cGMP-stimulated phosphodiesterase (PDE2) and guanylyl cyclase-D define a unique olfactory signal transduction pathway. Proc Natl Acad Sci U S A 94:3388-3395.

Junek S, Chen T-W, Alevra M and Schild D (2009) Activity correlation imaging: visualizing function and structure of neuronal populations. Biophys J 96:3801-3809.

Junek S, Kludt E, Wolf F and Schild D (2010) Olfactory coding with patterns of response latencies. Neuron in press.

Kajiya K, Inaki K, Tanaka M, Haga T, Kataoka H and Touhara K (2001) Molecular bases of odor discrimination: reconstitution of olfactory receptors that recognize overlapping sets of odorants. J Neurosci 21:6018-6025.

Kang J and Caprio J (1995) In vivo responses of single olfactory receptor neurons in the channel catfish, Ictalurus punctatus. J Neurophysiol 73:172-177.

Katada S, Tanaka M and Touhara K (2004) Structural determinants for membrane trafficking and G protein selectivity of a mouse olfactory receptor. J Neurochem 90:1453-1463.

Katada S, Hirokawa T, Oka Y, Suwa M and Touhara K (2005) Structural basis for a broad but selective ligand spectrum of a mouse olfactory receptor: mapping the odorant-binding site. J Neurosci 25:1806-1815.

Kato A, Katada S and Touhara K (2008) Amino acids involved in conformational dynamics and $\mathrm{G}$ protein coupling of an odorant receptor: targeting gain-of-function mutation. J Neurochem 107:1261-1270.

Kaur R, Zhu XO, Moorhouse AJ and Barry PH (2001) IP3-gated channels and their occurrence relative to $\mathrm{CNG}$ channels in the soma and dendritic knob of rat olfactory receptor neurons. J Membr Biol 181:91-105.

Kiefer H, Krieger J, Olszewski JD, Von Heijne G, Prestwich GD and Breer H (1996) Expression of an olfactory receptor in Escherichia coli: purification, reconstitution, and ligand binding. Biochemistry 35:16077-16084.

Kleene SJ and Gesteland RC. (1991) Calcium-activated chloride conductance in frog olfactory cilia. J Neurosci 11:3624-3629. 
Kleene SJ and Gesteland RC. (1993) Origin of the chloride current in olfactory transduction. Neuron 11:123-132.

Kleene SJ (2008) The electrochemical basis of odor transduction in vertebrate olfactory cilia. Chem Senses 33:839-859.

Klein SL and Graziadei PP (1983) The differentiation of the olfactory-placode in Xenopus laevis. a light and electron microscope study. J Comp Neurol 217:17-30.

Kludt E (2009) Bilateral processing of thermoreception in the olfactory system of Xenopus laevis tadpoles. (doctoral dissertation)

Ko HJ and Park TH (2006) Dual signal transduction mediated by a single type of olfactory receptor expressed in a heterologous system. Biol Chem 387:59-68.

Kobayakawa K, Kobayakawa R, Matsumoto H, Oka Y, Imai T, Ikawa M, Okabe M, Ikeda T, Itohara S, Kikusui T, Mori K and Sakano H (2007) Innate versus learned odour processing in the mouse olfactory bulb. Nature 450:503-508.

Kramer RH and Siegelbaum SA (1992) Intracellular Ca2+ regulates the sensitivity of cyclic nucleotide-gated channels in olfactory receptor neurons. Neuron 9:897-906.

Kratz E, Dugas JC and Ngai J (2002) Odorant receptor gene regulation: implications from genomic organization. Trends Genet 18:29-34.

Krautwurst D, Yau KW and Reed RR (1998) Identification of ligands for olfactory receptors by functional expression of a receptor library. Cell 95:917-926.

Krieger J, Mameli M and Breer H (1997) Elements of the olfactory signaling pathways in insect antennae. Invert Neurosci 3:137-144.

Kurahashi T and Menini A (1997) Mechanism of odorant adaptation in the olfactory receptor cell. Nature 385:725-729.

Laing DG, Cain WS, McBride RL and Ache BW (1989) Perception of Complex Smell and Tastes. Sydney, Australia: Academic Press.

Lang F and Lang P (2007) Basiswissen Physiologie, 2nd edition (Springer Berlin Heidelberg).

Lazard D, Zupko K, Poria Y, Nef P, Lazarovits J, Horn S, Khen M and Lancet D (1991) Odorant signal termination by olfactory UDP glucuronosyl transferase. Nature 349:790-793. 
Lazic SE, Goodman AO, Grote HE, Blakemore C, Morton AJ, Hannan AJ, van Dellen A and Barker RA (2007) Olfactory abnormalities in Huntington's disease: decreased plasticity in the primary olfactory cortex of R6/1 transgenic mice and reduced olfactory discrimination in patients. Brain Res 1151:219-226.

Leinders-Zufall $\mathrm{T}$ and Zufall F (1995) Block of cyclic nucleotide-gated channels in salamander olfactory receptor neurons by the guanylyl cyclase inhibitor LY83583. J Neurophysiol 74:2759-2762.

Leinders-Zufall T, Ma M and Zufall F (1999) Impaired odor adaptation in olfactory receptor neurons after inhibition of $\mathrm{Ca}^{2+} /$ calmodulin kinase II. J Neurosci 19:RC19.

Leinders-Zufall T, Cockerham RE, Michalakis S, Biel M, Garbers DL, Reed RR, Zufall F and Munger SD (2007) Contribution of the receptor guanylyl cyclase GCD to chemosensory function in the olfactory epithelium. Proc Natl Acad Sci U S A 104:14507-14512.

Lewcock JW and Reed RR (2004) A feedback mechanism regulates monoallelic odorant receptor expression. Proc Natl Acad Sci U S A 101:1069-1074.

Li J, Ishii T, Feinstein P and Mombaerts P (2004) Odorant receptor gene choice is reset by nuclear transfer from mouse olfactory sensory neurons. Nature 428:393399.

Liberles SD and Buck LB (2006) A second class of chemosensory receptors in the olfactory epithelium. Nature 442:645-650.

Liu M, Chen TY, Ahamed B, Li J and Yau KW (1994) Calcium-calmodulin modulation of the olfactory cyclic nucleotide-gated cation channel. Science 266:1348-1354.

Lledo PM, Gheusi G and Vincent JD (2005) Information processing in the mammalian olfactory system. Physiol Rev 85:281-317.

Lombion-Pouthier S, Vandel P, Nezelof S, Haffen E and Millot JL (2006) Odor perception in patients with mood disorders. J Affect Disord 90:187-191.

Ma M (2007) Encoding olfactory signals via multiple chemosensory systems. Crit Rev Biochem Mol Biol 42:463-480.

Malnic B, Hirono J, Sato T and Buck LB (1999) Combinatorial receptor codes for odors. Cell 96:713-723. 
Malnic B, Godfrey PA and Buck LB (2004) The human olfactory receptor gene family. Proc Natl Acad Sci US A 101:2584-2589.

Manzini I, Rössler W and Schild D (2002) cAMP-independent responses of olfactory neurons in Xenopus laevis tadpoles and their projection onto olfactory bulb neurons. J Physiol 545:475-484.

Manzini I and Schild D (2003a) cAMP-independent olfactory transduction of amino acids in Xenopus laevis tadpoles. J Physiol 551:115-123.

Manzini I and Schild D (2003b) Multidrug resistance transporters in the olfactory receptor neurons of Xenopus laevis tadpoles. J Physiol 546:375-385.

Manzini I and Schild D (2004) Classes and narrowing selectivity of olfactory receptor neurons of Xenopus laevis tadpoles. J Gen Physiol 123:99-107.

Manzini I, Brase C, Chen TW and Schild D (2007) Response profiles to amino acid odorants of olfactory glomeruli in larval Xenopus laevis. J Physiol 581:567-579.

Manzini I, Schweer TS and Schild D (2008) Improved fluorescent (calcium indicator) dye uptake in brain slices by blocking multidrug resistance transporters. J Neurosci Methods 167:140-147.

Matsunami H and Buck LB (1997) A multigene family encoding a diverse array of putative pheromone receptors in mammals. Cell 90:775-784.

Mazumder B, Seshadri V and Fox PL (2003) Translational control by the 3-UTR: the ends specify the means. Trends Biochem Sci 28:91-98.

McClintock TS and Sammeta N (2003) Trafficking prerogatives of olfactory receptors. Neuroreport 14:1547-1552.

Meyer MR, Angele A, Kremmer E, Kaupp UB and Muller F (2000) A cGMPsignaling pathway in a subset of olfactory sensory neurons. Proc Natl Acad Sci $U S A$ 97:10595-10600.

Mezler M, Konzelmann S, Freitag J, Rössler P and Breer H (1999) Expression of olfactory receptors during development in Xenopus laevis. J Exp Biol 202:365-376.

Mezler M, Fleischer J and Breer H (2001) Characteristic features and ligand specificities of the two olfactory receptor classes from Xenopus laevis. J Exp Biol 204:2987-2997. 
Michel WC and Ache BW (1994) Odor-evoked inhibition in primary olfactory receptor neurons. Chem Senses 19:11-24.

Mombaerts P (1999) Molecular biology of odorant receptors in vertebrates. Annu Rev Neurosci 22:487-509.

Mombaerts P (2004) Odorant receptor gene choice in olfactory sensory neurons: the one receptor-one neuron hypothesis revisited. Curr Opin Neurobiol 14:31-36.

Mombaerts P, Wang F, Dulac C, Chao SK, Nemes A, Mendelsohn M, Edmondson J and Axel R (1996) Visualizing an olfactory sensory map. Cell 87:675-686.

Mombaerts P (1996) Targeting olfaction. Curr Opin Neurobiol 6(4):481-486.

Morales B, Ugarte G, Labarca P and Bacigalupo J (1994) Inhibitory K+ current activated by odorants in toad olfactory neurons. Proc Biol Sci 22:235-242.

Morales B, Labarca P and Bacigalupo J (1995) A ciliary K+ conductance sensitive to charibdotoxin underlies inhibitory responses in toad olfactory receptor neurons. FEBS Lett 359:41-44.

Morales B and Bacigalupo J (1996) Chemical reception in vertebrate olfaction: evidence for multiple transduction pathways. Biol Res 29:333-341.

Morales B, Madrid R and Bacigalupo J (1997) Calcium mediates the activation of the inhibitory current induced by odorants in toad olfactory receptor neurons. FEBS Lett 402:259-264.

Mori K, Nagao H and Yoshihara Y (1999) The olfactory bulb: coding and processing of odor molecule information. Science 286:711-715.

Mori K, Takahashi YK, Igarashi KM and Yamaguchi M (2006) Maps of odorant molecular features in the Mammalian olfactory bulb. Physiol Rev 86:409-433.

Munger SD, Leinders-Zufall T and Zufall F (2009) Subsystem organization of the mammalian sense of smell. Annu Rev Physiol 71:115-140.

Nagawa F, Yoshihara S, Tsuboi A, Serizawa S, Itoh K and Sakano H (2002) Genomic analysis of the murine odorant receptor MOR28 cluster: a possible role of gene conversion in maintaining the olfactory map. Gene 292:73-80.

Nakamura T and Gold GH (1987) A cyclic nucleotide-gated conductance in olfactory receptor cilia. Nature 325:442-444. 
Nef P, Hermans-Borgmeyer I, Artières-Pin H, Beasley L, Dionne VE and Heinemann SF (1992) Spatial pattern of receptor expression in the olfactory epithelium. Proc Natl Acad Sci U S A 89:8948-8952.

Nezlin LP and Schild D (2000) Structure of the olfactory bulb in tadpoles of Xenopus laevis Cell Tissue Res 302:21-29.

Nezlin LP and Schild D (2005) Individual olfactory sensory neurons project into more than one glomerulus in Xenopus laevis tadpole olfactory bulb. J Comp Neurol 481:233-239.

Ngai J, Dowling MM, Buck L, Axel R and Chess A (1993) The family of genes encoding odorant receptors in the channel catfish. Cell 72:657-666.

Nguyen MQ, Zhou Z, Marks CA, Ryba NJ and Belluscio L (2007) Prominent roles for odorant receptor coding sequences in allelic exclusion. Cell 131:1009-1017.

Nieuwkoop PD and Faber J (1994) Normal Table of Xenopus laevis (Daudin) (Garland, New York).

Niimura Y and Nei M (2005a) Evolutionary dynamics of olfactory receptor genes in fishes and tetrapods. Proc Natl Acad Sci U S A 102:6039-6044

Niimura Y and Nei M (2005b) Evolutionary changes of the number of olfactory receptor genes in the human and mouse lineages. Gene 346:23-28.

Niimura Y and Nei M (2006) Evolutionary dynamics of olfactory and other chemosensory receptor genes in vertebrates. J Hum Genet 51:505-517.

Nimmermark S (2004) Odour influence on well-being and health with specific focus on animal production emissions. Ann Agric Environ Med 11:163-173.

Nordin S and Brämerson A (2008) Complaints of olfactory disorders: epidemiology, assessment and clinical implications. Curr Opin Allergy Clin Immunol 8:10-15.

Oka Y, Omura M, Kataoka H and Touhara K (2004) Olfactory receptor antagonism between odorants. EMBO J 23:120-126.

Oka Y, Takai Y and Touhara K (2009) Nasal airflow rate affects the sensitivity and pattern of glomerular odorant responses in the mouse olfactory bulb. J Neurosci 29:12070-12078.

Pilpel Y and Lancet D (1999) The variable and conserved interfaces of modeled olfactory receptor proteins. Protein Sci 8:969-977. 
Raming K, Krieger J, Strotmann J, Boekhoff I, Kubick S, Baumstark C and Breer H (1993) Cloning and expression of odorant receptors. Nature 361:353-356.

Rawson NE, Gomez G, Cowart B, Brand JG, Lowry LD, Pribitkin EA and Restrepo D (1997) Selectivity and response characteristics of human olfactory neurons. $J$ Neurophysiol 77:1606-1613.

Rawson NE, Eberwine J, Dotson R, Jackson J, Ulrich P and Restrepo D (2000) Expression of mRNAs encoding for two different olfactory receptors in a subset of olfactory receptor neurons. J Neurochem 75:185-195.

Ressler KJ, Sullivan SL and Buck LB (1993) A zonal organization of odorant receptor gene expression in the olfactory epithelium. Cell 73:597-609.

Ressler KJ, Sullivan SL and Buck LB (1994) Information coding in the olfactory system: evidence for a stereotyped and highly organized epitope map in the olfactory bulb. Cell 79:1245-1255.

Restrepo D, Okada Y, Teeter JH, Lowry LD, Cowart B and Brand JG (1993) Human olfactory neurons respond to odor stimuli with an increase in cytoplasmic Ca2+. Biophys J 64:1961-1966.

Revial MF, Sicard G, Duchamp A and Holley A (1982) New studies on odour discrimination in frog's olfactory receptor cells. I. Experimental results ${ }^{6}$ Chem Senses 7:175-190

Rodriguez I, Greer CA, Mok MY and Mombaerts P (2000) A putative pheromone receptor gene expressed in human olfactory mucosa. Nat Genet 26:18-19.

Rodriguez I and Mombaerts P (2002) Novel human vomeronasal receptor-like genes reveal species-specific families. Curr Biol 2002 12:R409-411.

Rolls ET (2005) Taste, olfactory, and food texture processing in the brain, and the control of food intake. Physiol Behav 85:45-56.

Ronnett GV and Moon C (2002) G proteins and olfactory signal transduction. Annu Rev Physiol 64:189-222.

Royet JP, Souchier C, Jourdan F and Ploye H (1988) Morphometric study of the glomerular population in the mouse olfactory bulb: numerical density and size distribution along the rostrocaudal axis. J Comp Neurol 270:559-568. 
Saito H, Kubota M, Roberts RW, Chi Q and Matsunami H (2004) RTP family members induce functional expression of mammalian odorant receptors. Cell 119:679-691.

Sato Y, Miyasaka N and Yoshihara Y (2007) Hierarchical regulation of odorant receptor gene choice and subsequent axonal projection of olfactory sensory neurons in zebrafish. $J$ Neurosci 27:1606-1615.

Schild D (1985) A computer-controlled device for the application of odours to aquatic animals. J Electrophysiol Techn 12:71-79.

Schild D (1989) Whole-cell currents in olfactory receptor cells of Xenopus laevis. Exp Brain Res 78:223-232.

Schild D, Jung A and Schultens HA (1994) Localization of calcium entry through calcium channels in olfactory receptor neurones using a laser scanning microscope and the calcium indicator dyes Fluo-3 and Fura-Red. Cell Calcium 15:341-348.

Schild D, Gennerich A and Schultens HA (1996) Microcontrollers as inexpensive pulse generators and parallel processors in electrophysiological experiments. Med Biol Eng Comput 34:305-307.

Schild D (1995) Signal integration in the olfactory system. Trends Neurosci 17:366367.

Schild D and Manzini I (2004) Cascades of response vectors of olfactory receptor neurons in Xenopus laevis tadpoles. Eur J Neurosci 20:2111-2123.

Schild D and Restrepo D (1998) Transduction mechanisms in vertebrate olfactory receptor cells. Physiol Rev 78:429-466.

Schleicher S, Boekhoff I, Arriza J, Lefkowitz RJ and Breer H (1993) A betaadrenergic receptor kinase-like enzyme is involved in olfactory signal termination. Proc Natl Acad Sci U S A0:1420-1424.

Schultz EF and Tapp JT (1973) Olfactory control of behavior in rodents. Psychol Bull 79:21-44.

Schwob JE (2002) Neural regeneration and the peripheral olfactory system. Anat Rec 269:33-49.

Serizawa S, Ishii T, Nakatani H, Tsuboi A, Nagawa F, Asano M, Sudo K, Sakagami J, Sakano H, Ijiri T, Matsuda Y, Suzuki M, Yamamori T, Iwakura Y and Sakano 
H (2000) Mutually exclusive expression of odorant receptor transgenes. Nat Neurosci 3:687-693.

Serizawa S, Miyamichi K, Nakatani H, Suzuki M, Saito M, Yoshihara Y and Sakano H (2003) Negative feedback regulation ensures the one receptor-one olfactory neuron rule in mouse. Science 302:2088-2094.

Serizawa S, Miyamichi K and Sakano H (2004) One neuron-one receptor rule in the mouse olfactory system. Trends Genet 20:648-653.

Shirley SG, Robinson CJ, Dickinson K, Aujla R and Dodd GH (1987) Olfactory adenylate cyclase of the rat. Stimulation by odorants and inhibition by $\mathrm{Ca} 2+$. Biochem J 240: 605-607.

Shirokova E, Schmiedeberg K, Bedner P, Niessen H, Willecke K, Raguse JD, Meyerhof W and Krautwurst D (2005) Identification of specific ligands for orphan olfactory receptors. G protein-dependent agonism and antagonism of odorants. $J$ Biol Chem 280:11807-11815.

Shykind BM, Rohani SC, O’Donnell S, Nemes A, Mendelsohn M, Sun Y, Axel R and Barnea G (2004) Gene switching and the stability of odorant receptor gene choice. Cell 117:801-815.

Singer MS, Oliveira L, Vriend G and Shepherd GM (1995) Potential ligand-binding residues in rat olfactory receptors identified by correlated mutation analysis. Receptors Channels 3:89-95.

Singer MS (2000) Analysis of the molecular basis for octanal interactions in the expressed rat 17 olfactory receptor. Chem Senses 25:155-165.

Sinnarajah S, Dessauer CW, Srikumar D, Chen J, Yuen J, Yilma S, Dennis JC, Morrison EE, Vodyanoy V and Kehrl JH (2001) RGS2 regulates signal transduction in olfactory neurons by attenuating activation of adenylyl cyclase III. Nature 409:1051-1055.

Speca DJ, Lin DM, Sorensen PW, Isacoff EY, Ngai J and Dittman AH (1999) Functional identification of a goldfish odorant receptor. Neuron 23:487-498.

Spehr M, Gisselmann G, Poplawski A, Riffell JA, Wetzel CH, Zimmer RK and Hatt $\mathrm{H}$ (2003) Identification of a testicular odorant receptor mediating human sperm chemotaxis. Science 299:2054-2058. 
Strotmann J, Wanner I, Krieger J, Raming K and Breer H (1992) Expression of odorant receptors in spatially restricted subsets of chemosensory neurones. Neuroreport 3:1053-1056.

Strotmann J, Conzelmann S, Beck A, Feinstein P, Breer H and Mombaerts P (2000) Local permutations in the glomerular array of the mouse olfactory bulb. $J$ Neurosci 20:6927-6938.

Strotmann J, Levai O, Fleischer J, Schwarzenbacher K and Breer H (2004) Olfactory receptor proteins in axonal processes of chemosensory neurons. J Neurosci 24:77547761.

Takahashi LK, Nakashima BR, Hong H and Watanabe K (2005) The smell of danger: a behavioral and neural analysis of predator odor-induced fear. Neurosci Biobehav Rev 29:1157-1167.

Tareilus E, Noé J and Breer H (1995) Calcium signals in olfactory neurons. Biochim Biophys Acta 1269:129-138.

Tian H and Ma M (2008) Activity plays a role in eliminating olfactory sensory neurons expressing multiple odorant receptors in the mouse septal organ. Mol Cell Neurosci 38:484-488.

Toller SV (1999) Assessing the impact of anosmia: review of a questionnaire's findings. Chem Senses 24:705-712.

Touhara K, Sengoku S, Inaki K, Tsuboi A, Hirono J, Sato T, Sakano H and Haga T (1999) Functional identification and reconstitution of an odorant receptor in single olfactory neurons. Proc Natl Acad Sci U S A 96:4040-4045

Touhara K (2001) Functional cloning and reconstitution of vertebrate odorant receptors. Life Sci 68:2199-2206.

Treloar HB, Feinstein P, Mombaerts P and Greer CA (2002) Specificity of glomerular targeting by olfactory sensory axons. J Neurosci 22:2469-2477.

Trudeau MC and Zagotta WN (2003) Calcium/calmodulin modulation of olfactory and rod cyclic nucleotide-gated ion channels. J Biol Chem 278:18705-18708.

Tsuboi A, Yoshihara S, Yamazaki N, Kasai H, Asai-Tsuboi H, Komatsu M, Serizawa S, Ishii T, Matsuda Y, Nagawa F and Sakano H (1999) Olfactory neurons expressing closely linked and homologous odorant receptor genes tend to project 
their axons to neighboring glomeruli on the olfactory bulb. J Neurosci 19:84098418.

Tsuboi A, Miyazaki T, Imai T and Sakano H (2006) Olfactory sensory neurons expressing class I odorant receptors converge their axons on an antero-dorsal domain of the olfactory bulb in the mouse. Eur $J$ Neurosci 23:1436-1444.

Vassalli A, Rothman A, Feinstein P, Zapotocky M and Mombaerts P (2002) Minigenes impart odorant receptor-specific axon guidance in the olfactory bulb. Neuron 35:681-696.

Vassar R, Ngai J and Axel R (1993) Spatial segregation of odorant receptor expression in the mammalian olfactory epithelium. Cell 74:309-318.

Vassar R, Chao SK, Sitcheran R, Nuñez JM, Vosshall LB and Axel R (1994) Topographic organization of sensory projections to the olfactory bulb. Cell 79:981991.

Vogl A, Noé J, Breer H and Boekhoff I (2000) Cross-talk between olfactory second messenger pathways. Eur J Biochem 267:4529-4535.

Vogler C and Schild D (1999) Inhibitory and excitatory responses of olfactory receptor neurons of Xenopus laevis tadpoles to stimulation with amino acids. $J$ Exp Biol 202:997-1003.

Von Dannecker LE, Mercadante AF and Malnic B (2006) Ric-8B promotes functional expression of odorant receptors. Proc Natl Acad Sci U S A 103(24):9310-9314.

Wachowiak M and Shipley MT (2006) Coding and synaptic processing of sensory information in the glomerular layer of the olfactor bulb Semin Cell Dev Biol 17:411-423.

Wakabayashi Y, Mori Y, Ichikawa M, Yazaki K and Hagino-Yamagishi K (2002) A putative pheromone receptor gene is expressed in two distinct olfactory organs in goats. Chem Senses 27:207-213.

Wang S, Sato K, Giurfa M and Zhang S (2008) Processing of sting pheromone and its components in the antennal lobe of the worker honeybee. J Insect Physiol 54:833841.

Weth F, Nadler W and Korsching S (1996) Nested expression domains for odorant receptors in zebrafish olfactory epithelium. Proc Natl Acad Sci U S A 93:1332113326. 
Wilson RI and Mainen ZF (2006) Early events in olfactory processing. Annu Rev Neurosci 29:163-201.

Yan C, Zhao AZ, Bentley JK, Loughney K, Ferguson K and Beavo JA (1995) Molecular cloning and characterization of a calmodulin-dependent phosphodiesterase enriched in olfactory sensory neurons. Proc Natl Acad Sci USA 92:9677-9681.

Yeomans MR (2006) Olfactory influences on appetite and satiety in humans. Physiol Behav 87:800-804.

Young JM, Friedman C, Williams EM, Ross JA, Tonnes-Priddy L and Trask BJ (2002) Different evolutionary processes shaped the mouse and human olfactory receptor gene families. Hum Mol Genet 11:1683.

Young JM and Trask BJ (2002) The sense of smell: genomics of vertebrate odorant receptors. Hum Mol Genet 11:1153-1160.

Zhang X and Firestein S (2002) The olfactory receptor gene superfamily of the mouse. Nat Neurosci 5:124-133.

Zhang X, Rodriguez I, Mombaerts P and Firestein S (2004) Odorant and vomeronasal receptor genes in two mouse genome assemblies. Genomics 83:802-811.

Zhao H, Ivic L, Otaki JM, Hashimoto M, Mikoshiba K and Firestein S (1998) Functional expression of a mammalian odorant receptor. Science 279:237-242.

Zozulya S, Echeverri F and Nguyen T (2001) The human olfactory receptor repertoire. Genome Biol 2:RESEARCH0018.

Zufall F and Leinders-Zufall T (1998) Role of cyclic GMP in olfactory transduction and adaptation. Ann N Y Acad Sci 855:199-204.

Zufall F, Kelliher KR and Leinders-Zufall T (2002) Pheromone detection by mammalian vomeronasal neurons. Microsc Res Tech 58:251-260.

Zufall F and Leinders-Zufall T (2007) Mammalian pheromone sensing. Curr Opin Neurobiol 17:483-489. 


\section{SUPPLEMENTARY FIGURES}

\section{(1) $X R 46 / 106 / 117$}

XR46/106/117_nested PCR TATCAGTGATGACTTACATGATCCTTAAATTGCCCTTT TGTGGTCCAAAT 50 XR46_database TATCAGTGATGACTTACATGATCCTTAAATTGCCСTTTTGTGGTCCAAAT 50 XR106_databese TATCAGTGATGACTTACATGATCCTTAAATTGCCCTTTTGTGGTCCAAAT 50 XR117_databese TATCAGTGATGACTTACATGATCCTTAAATTGCCCTTTTGTGGTCCAAAT 50

XR46/106/117_nested PCR AATATCACTGGCTGTTTTTGTTCTAGTTCAGTGATATTTCCTTTGGCTTG 100 XR46_database AATATCACTGGCTGTTTTTGTTCTAGTTCAGTGATATTTCCTTTGGCTTG 100 XR108 database AATATCACTGGCTGTTTTTGTTCTAGTTCAGTGATATTTCCTTTGGCTTG 100 XR117_database AATATCACTGGCTGTTTTTGTTCTAGTTCAGTGATATTTCCTTTGGCTTG 100 XR46/108/117_nested PCR TACGGATGTCACGTATGTTCGGCAAGTAAGTTTAATCTTTGCGCTGAGTG 150 XR46 database TACAGATGTCACGTATGTTCGGCAAGTAAGTTTAATCT TTGCGCTGAGTG 150 XR106 database TACGGATGTCACGTATGTTCGGCAAGTAAGTTTAATCT T TGCGTGAGTG 150 XR117_database TACGGATGTCACGTATGTTCGGCAAGTAAGTTTAATCTTTGCGCTGAGTG 150

XR46/106/117 nested PCR TTCTCCTAATACCATTGGCTTTCATCATATTGTCCTATGCCCTCATAGTC 200 XR46 database TTCTCCTAATACCATTGGCTTTCATCATATTGTCCTATGCCCTCATAGTC 200 XR106_database TTCTCCTAATACCATTGGCTTTCATCATATTGTCCTATGCCCTCATAGTC 200 XR117_database TTCTCCTAATACCATTGGCTTTCATCATATTGTCCTATGCCCTCATAGTC 200

XR46/106/117_nested PCR CTCACCATCCACTCCATGTTACACTCGGACAACT 234 XR4̄6_database CTCACCATCCACTCCATGTTACACTCGGACAACT 234 XR106_database CTCACCATCCACTCCATGTTACACTCGGACAACT 234 XR117_database CTCACCATCCACTCCATGTTACACTCGGACAACT 234

\section{(2) $X R 116$}

XR116 nested PCR GTGACTCTCCTCTGCTACTTTTTCTGGGTCCTTGCTGCCCTAATTGGCTT 50 XR116_database GTGACTCTCCTCTGCTACTTTTTCTGGGTCCTTGCTGCCCTAATTGGCTC 50

XR116_nested PCR CATTGTTGCAGTCATAGCTGGACAACTGCCTTACTGTGGGCCCAATCGTG 100 XR116_database TATTGTTGCAGTCATAGCTGGACAACTGCCTTACTGTGGGCCCAATCGTG 100 XR116_nested PCR TCAGGAACTGTTTCTGTGTCAATTCAGCAGTCACAGTGTTGGCGTGTGTA 150 XR116_database TCAGGAACTGTTTCTGTGTCAATTCAGCAGTCACAGTGTTGGCGTGTGTA 150

XR116_nested PCR GATGTTACATTGGCAAGACGGACGGTTTTTACT 183 XR116_database GATGTTACATTGGCAAGACGGACGGTTTTTACT 183

\section{(3) $X b$ 238/Xb 107/239}

Xb238/107_nested PCR CTGCTACTTTTGCT TGGTATGTGCTGCGCTAAT TGGAT TAGCTATTACTT 50 Xb238_database CTGCTACT TTTGCTTGGTATGTGCTGCGCTAAT TGGAT TAGCTAT TACT T 50 Xb107_database CTGCTACTTTTGCTCGGTTTGTGCTGCGCTAAT TGGATTAGCTCTTACT 50

Xb238/107 nested PCR TAATTGCTGGAATTCTTTCTTACTGTGGACCCAACCGTGTCAAGAACTGT 100 Xb238_database TAATTGCTGGAAT TCT TTCTTACTGTGGACCCAACCGTGTCAAGAACTGT 100 Xb107_database TAATTGCTGGAAT TCTTCCTTACTGTGGACCCAACCGTGTCAAGAACTGT 100

Xb238/107_nestod PCR TTCTGTGCCAGCCAATCTGTAATAGT T T TGGCATGTGT TGATGTTTCT TT 150 Xb238_database TTCTGTGCCAGCCAATCTGTAATAGTTTTGGCATGTGT TGATGTTTCTTT 150 Xb107_database TTCTGTGCCACACAATCTGTAATAGTTTTGGCATGTGTTGATGTTTCTTT 150

Xb238/107 nested PCR GGAAAGA 157 Xb238_database GGAAAGA 157 Xb107_database GGAAAGA 157

\section{(4) $X b 242$}

Xb242 nested PCR TTGTTGGTTTTGGTGGCTCTGTGCTGCTCTAATTGGATTGATGATTGCTT 50 Xb242_database TTGTTGGTTTGGTGGCTCTGTGCTGCTCTAATTGGATTGATGATTGCTT 50 Xb242_nested PCR TAATGACCGGTCAACTCCCTTACTGTGGACGTAACCGTGTTGAGAACTGT 100 Xb242_database TAATGACCGGTCAACTCCCTTACTGTGGACGTAACCGTGTTGAGAACTGT 100

Xb242_nested PCR TTCTGTACCAATGCAGTGGTATTAGTGTTGGCATGTGCCGATATCAC 147 Xb242_database TTCTGTACCAATGCAGTGGTATTAGTGTTGGCATGTGCCGATATCAC 147

Supplementary figure 1: Sequence alignments. Alignments of the partial DNA sequences encoding the tested class I ORs of the PCR amplicons and the GenBank database. Differences are highlighted in light grey. 


\section{(7) $X b 178$}

Xb178_nested PCR CTCACTTGTTCATTGCGTCTCACCAATATCATGGCCACACTACAGTTTTG 50 Xb178_database CTCACTTGTTCATTGCGTCTCACCAATATCATGGCCACACTACAGTTTTG 50

Xb178_nested PCR TGACCAAAATATAATTTACCATTTCTTCTGTGATTTCTTTCCTCTTCTAG 100 Xb178_database TGACCAAAATATAATTTACCATTTCT TCTGTGATTTCTTTCCTCTTCTAG 100

Xb178 nested PCR AACTTTCCTGCTCAGATACATTTT TAATGCAGATAACTAT TACCTTACAG 150 Xb178_database AACTTTCCTGCTCAGATACATTTTTAATGCAGATAACTATTACCTTACAG 150 Xb178_nested PCR TC 152 Xb178_database TC 152

\section{(8) $X b 180$}

Xb180_nested PCR TGCT AGCCTCATTGGCGTACTCATTATTGCCAAAATTATGGCTACCTTA 50 Xb180_database TGCT TAGCCTCATTGGCGTACTCATTATTGCCAAAATTATGGCTACCTTA 50

Xb180 nested PCR CAGT TCTGTGACCAAAACACGATTAACCATTTCTTCTGTGATTTCTTTCC 100 Xb180_database CAGTTCTGTGACCAAAACACGATTAACCATTTCTTCTGTGATTTCTTTCC 100

Xb180 nested PCR TATAGTAGAGCT TTCTTGCTCAGACACTTACCTGGTGCATATAAATATTA 150 Xb180_database TATAGTAGAGCTTTCTTGCTCAGACACTTACCTGGTGCATATAAATATTA 150 Xb180 nested PCR TG 152 Xb180_database TG 152

\section{(9) $X b 177$}

Xb177_nested PCR TTTCAGTGAATCCAATAACAATGTTACAGTTTTGTGATCGAAACACCATT 50 Xb177_database TTTCAGTGAATCCAATAACAATGTTACAGTTTTGTGATCGAAACACCATT 50

Xb177_nestød PCR AATCATTTCTTTTGCGATTTCTTTCCCCTTCTTGGGCTTATTTGCTCAGA 100 Xb177_database AATCATTTCTTTTGCGATTTCTTTCCCCTTCTTGGGCTTATTTGCTCAGA 100

Xb177_nested PCR CACTTCTTTTGTTCAAATACAAGCAATCATACAGTCAT 138 Xb177_database CACTTCTTTTGTTCAAATACAAGCAATCATACAGTCAT 138

$$
\text { (10) } X b 350
$$

Xb350_nestedPCR CTGCTTGGTGTTATTATAACGT TCAATACTGGAAATGCCATATGCAAGCT 50 Xb350_database CTGCTTGGTGTTATTATAACGTTCAATACTGGAAATGCCATATGCAAGCT 50

Xb350_nestedPCR CCAATTTGGTAATCAAAATTCTATTGACCATTTTTTTGTGATTTCTTCC 100 Xb350_database CCAATTTGGTAATCAAAAT TCTATTGACCATTTTTTTGTGATTTCTTCC 100

Xb350_nested PCR CTCTTGTTGAACTTTCATACTCAAACAATTTCTTCTTTCATATAGAAGTA 150 Xb350_database CTCTTGTTGAACTTTCATACTCAAACAATTTCTTCTTTCATATAGAAGTA 150

Xb350_nestedPCR ATTTTATCGTCGGT 164 Xb350_database ATTTTATCGTCGGT 164

\section{(11) $X b 350$}

Xb352_nested PCR AGCAAATCTAATAGGAGCAT TAGAGTTTTGTGACCAAAATACCAT TAATC 50 Xb352_database AGCAAATCTAATAGGAGCAT TAGAGT T T TGTGACCAAAATACCAT TAATC 50

Xb352_nested PCR ATTTCTTCTGTGATTTCTACCCTCTTTTAGAACTTTCCTGCTCAGATACT 100 Xb352_database ATTTCTTCTGTGATTTCTACCCTCTTTTAGAACTTTCCTGCTCAGATACT 100

Xb352_nested PCR TTTTCTCTGCAATTTGAAGCATTTTTTTATTTGTCCCTATGGTTTTTCT 150 Xb352_database TTT TCTCTGCAAT T TGAAGCATTTTTTTATTTGTCCCTATGGTTTTTCT 150

Xb352_nested PCR ACCAT TCATACT TGTCATTG 170 Xb352_database ACCAT TCATACT TGTCAT TG 170

Supplementary figure 2: Sequence alignments. Alignments of the partial DNA sequences encoding the tested class II ORs of the PCR amplicons and the GenBank database. Differences are highlighted in light grey. 


\section{V1R deg}

V1R deg_PCR CAGTTTGCTCAGCTGTTATCAGTGTATCATCATTGCTCCACAAACAAGAC 50 Xt_V1R10_database Xt_V1R11_database Xt_V1R12_database Xt_V1R23_database CAGTTTGCTCAGCTGT TATCAGTGTATCATCATTGCTCCACAAACTAAAA 50 CAGTTTGCTCAGCTGTTATCAGTGTATTATCATTGCTCCACAAACTAGGT 50 CAGTTTGCTCAGCTGTTATCAGTGTATCATCATTGCTCCACAAACTAGAC 50 V1R deg_PCR CAGTTTGCTCAGCTGTTATCAGTGTATCATCATTGCTCCACAAACTAGAC 50 Xt_V1R10_database TCTGGGCATATCTGAAGCAAAAGGTGATGCAGAACGTATTCTTGATAACT 100 Xt_V1R11_database Xt V1R12 database TCTGGGCATATCTGAAGCAAAAGGCAATGCAGAACGTGTTGCTAATAACT 100 TGTGGGCATATCTGAAGCAGAAGGCAATGCAGAATGTATTCTTCATAACT 100 TCTGGGCATATCTGAGGCAAAAGGCAATGCAGAATGTGTTGCTAATAACT 100

Xt_V1R23_database V1R deg_PCR

Xt_V1R10_database TCTGGGCATATCTGAAGCAAAAGGCAATGCAGAACGTGTTGCTAATAACT 100

ACAGCTGTCCTACTAATTAACCTCATAATATACCATAGTACCATTTTGTA 150 Xt V1R12 database ACTGCTGTCTTAATAGCCAACCTCATACTCTACCGCAATACCATTATGTA 150 Xt_v1R23_database ACTGCTGTCCTACTAGTCAACCTCATACTCTACCGTACTAGCATTATGTA 150 V1R deg_PCR TGCTATAGTGAGAAGAAATTCTACAACTTCACCATATACACTGCATTTAG 200 Xt V1R10 database TGCCATAGTAAAAAAAAAT TCTACAACCTCACCATATACATTGCGTTTAG 200 Xt_V1R11_database TGCTATAGCCAAAAACAAT TCTACAACT TCACCATATACTCTGCGTTTAG 200 Xt V1R12 database TGCTATAGTTAAAAAAAAT TCTACAACCTCACCGTATACGCTTCATTTAG 200 Xt_V1R23_database TGCCATAGTAAAAAAAAAT TCTACAACCTCACCATATGCATTGCGTTTAG 200 V1R deg_PCR TTTACTGTGACACGGACTATCTCAC 225 Xt V1R10_database TTTACTGTGACATGGACTATCTGAC 225 Xt_V1R11_database TTTACTGTGACATGGACTATCTGAC 225 XtV1R12_database TTTACTGTGACATGGACTATCTCAC 225 Xt_V1R23_database TTTACTGTGACACGGACTATCTGAC 225

Supplementary figure 3: Sequence alignments. Alignments of the partial DNA sequences encoding the tested V1Rs of the PCR amplicon and the Ensembl database. Differences are highlighted in light grey. 


\section{beta-actin}

beta-actin Cell 6 TACAGCT TCACCACCACAGCCGAAAGAGAAATCGTTCGTGATATCAAGGA 50 beta-actin_database TACAGCT TCACCACCACAGCCCAAAGAGAAATCGT TCGTGATATCAAGGA 50

beta-actin_Cell 6 GAAAT TGTGCTATGTTGCTCTGGACTTTGAGCAGGAGATGGCCACAGCTG 100 betactin_database GAAATTGTGCTATGTTGCTCTGGACT T TGAGCAGGAGATGGCCACAGCTG 100

beta-actin_Cell 6 CCTCTTCTTCATCATTGGAAAAGAGCTATGAGCTGCCTGANGGACAAGTC 150 beta-actin_database CCTCTTCTTCATCATTGGAAAAGAGCTATGAGCTGCCTGACGGACAAGTC 150

beta-actin_Cell 6 ATCACCAT TGGNAACGAGCGTTTTAGATGTCCAGAGGCCCTCTTCCAGCC 200 beta-actin_database ATCACCAT TGGTAACGAGCGTTTTAGATGTCCAGAGGCCCTCT TCCAGCC 200

beta-actin_Cell 6 ATCTTTCCTTGGTATGGAATCCTGCGGTAT 230

betaractn_database ATCTTTCCTTGGTATGGAATCCTGCGGTAT 230

\section{$X b 178$}

Xb178_nested PCR_Cell6 ATTAANCATTTCTTCTGTGATTGCTTTCCTCTTCTAGAACTTTCCTGCTC 50 Xb178_database ATTTACCATTTCTTCTGTGATTTCTTTCCTCTTCTAGAACT TCCTGCTC 50

Xb178_nested PCR_Cell 6 AGATACATTTTTAATGCAGATAACTATTACCTT 83

Xb178_database AGATACATTTTTAATGCAGATAACTATTACCTT 83

\section{$X b 180$}

Xb180_nested PCR_Cenl 6 TATGGCTACCT TACAGTTCTGTGACCAAAACACTAT TAACCATT TCT TTT 50 Xb180_database TATGGCTACCT TACAGTTCTGTGACCAAAACACGAT TAACCATTTCTTCT 50

Xb180_nested PCR_Cell 6 GTGATT TATT TCCTATAGTAGAGCTTTCTTGCTCAGACACT TACCTGGTG 100 Xb180_database GTGATTTCTTTCCTATAGTAGAGCTTTCTTGCTCAGACACT TACCTGGTG 100

Xb180_nestedPCR_Cell 6 CATATAAATATTATC 115

Xb180_database CATATAAATATTATO 115

\section{$X b 177$}

Xb177_nested PCR_Cell 6 TTTGTGATCGAAACACCATTAATCATTTCTTTTGTGATTTCTTTCCCCTT 50 Xb177_database TTTGTGATCGAAACACCATTAATCATTTCTTTTGCGATTTCTTTCCcCTT 50

Xb177_nested PCR_Cell 6 CTTGGGCTTGTTTGCTCAGACACCTCTTTTGTTCAAATACAAGCAATCAT 100 Xb177_database CTTGGGCTTATTTGCTCAGACACTTCTTTGTTCAAATACAAGCAATCAT 100

Xb177_nested PCR_Cell 6 ACAGTCAT 108

Xb177_databas $\theta$ ACAGTCAT 108

Supplementary figure 4: Sequence alignments. Alignments of the partial DNA sequences encoding $\beta$-actin and the tested receptors Xb 178, Xb 180 and Xb 177 of the Class II PCR amplicon and the GenBank database. Differences are highlighted in light grey. 


\section{ACKNOWLEDGEMENTS}

First of all, I want to thank my supervisors Prof. Detlev Schild and Ivan Manzini for the opportunity to work in the lab for the past years. Both gave me an incredible freedom to explore different techniques and methods, which helped to broaden my scientific horizon. The many discussion and suggestions were helpful throughout this thesis. Thanks to Ivan for his guidance, patience and simply for always being there with advice whenever I needed it.

Many thanks to Prof. Heinrich, Prof. Wienands and Prof. Ponimaskin from my $\mathrm{PhD}$ committee, who evaluated my work and gave useful advices and comments regularly.

Many thanks to Esther for a great time as a labmate and for many fruitful discussion concerning PCR experiments. Your expertise helped me in my struggle with some technical obstacles. Particularly, thanks for many nice after-work sessions and your grandmother's Blutwurz.

I am grateful to Arwed, for all his expertise and knowledge he shared and the support he gave regarding all optic devices. Particularly, thanks for many nice games evenings together with Gesa and the nice ambience during the Feuerzangenbowle sessions. Additionally I want to thank you for our wedding platform.

Thanks to Gudrun who helped and adviced me a lot in immunohistochemistry. Without her being the good soul in this lab, my time here would not have been so pleasant.

I want to thank all the people from the mechanical and electronic workshop for their great support and help whenever I needed it.

Thanks to everybody from the (old and current) lab, Arnaud, Bao, Belle, Dirk, Eiko, Eugen, Josko, Lars, Mihai, Robin, Sabine, Stephan, Stefanie, Thomas, TsaiWen and Valentin, for a great atmosphere and much advice.

Special thanks to Esther, Thomas, Mihai, Ivan and Uta for reading parts of this thesis and to Stephan, Mihai and Thomas for their help with MATLAB.

I want to thank the Göttingen $\mathrm{MSc} / \mathrm{PhD}$ Neurosciences program, and in particular Michael Hörner and Sandra Drube for their constant support and organization.

Many thanks go to Prof. Roeper and Prof. Liss, my former Professors in Marburg, who both motivated me to explore the field of neurosciences and finally encouraged me to join the Göttingen MSc/PhD Neurosciences program. 
Many thanks to the state of lower saxony, the Center for Molecular Brain Physiology and the DFG priority program/ SPP 1392, who provided funding for my work during these years.

My warmest thanks go to my parents, my brother Samuel and my wife Uta, who strenghtend and continuously encouraged me on my way. 


\title{
CURRICULUM VITAE
}

\author{
Personal details \\ Name Sebastian Gliem \\ Date of birth \\ March $31^{\text {st }} 1982$ \\ Place of birth \\ Rotenburg a.d. Fulda, Germany \\ Address Petrosilienstr. 14, 37073 Göttingen, Germany \\ Phone $\quad+49-551-3912203$ \\ E-mail sgliem@gwdg.de \\ Graduate Studies \\ since 2007 \\ Academic Degree \\ Master's thesis \\ 2007 \\ Undergraduate \\ Studies \\ $2005-2006$ \\ 2004 \\ $2002-2005$ \\ Education \\ International MSc/PhD/MD-PhD Program Neurosciences, \\ Department of Neurophysiology and Cellular Biophysics, \\ University Göttingen, Supervisors: Prof. Dr. Dr. D. Schild \\ and $\mathrm{PhD}$ I. Manzini \\ Master of Science \\ Optical characterization of amine olfactory receptors in \\ larval Xenopus laevis \\ Department of Neurophysiology and Cellular Biophysics, \\ University Göttingen, Supervisors: Prof. Dr. Dr. D. Schild \\ and PhD I. Manzini \\ High School \\ 2001 University entrance diploma, "Jakob Grimm Gymnasium" \\ 1999 - $2001 \quad$ "Jakob Grimm Gymnasium" in Rotenburg a.d. Fulda
}


$2001-2002$

\begin{tabular}{|c|c|}
\hline & Scholarships/Stipends \\
\hline 2010 & $\begin{array}{l}\text { Travel grant, European Chemoreception Research } \\
\text { Organisation }\end{array}$ \\
\hline $2007-2008$ & Lichtenberg Stipend \\
\hline $2005-2006$ & Max Planck Stipend \\
\hline & Laboratory experiences \\
\hline 2006 & $\begin{array}{l}\text { Calcium-imaging at odorant receptors of Xenopus laevis } \\
\text { tadpoles } \\
\text { Dept. of Neurophysiology and Cellular Biophysics, } \\
\text { University Göttingen }\end{array}$ \\
\hline 2006 & $\begin{array}{l}\text { Characterization of NSF-mediated SNARE-disassembly } \\
\text { applying a monoclonal antibody directed against the } N \text { - } \\
\text { terminal domain of NSF } \\
\text { Dept. of Neurobiology, Max-Planck-Institute for } \\
\text { Biophysical Chemistry, Göttingen }\end{array}$ \\
\hline 2006 & $\begin{array}{l}\text { Cholera toxin-sensitive proteins are involved in the } \\
\text { modulation of single } K_{A T P} \text {-channels by BDNF and ATP } \\
\text { Dept. of Neuro- and Sensoryphysiology, University } \\
\text { Göttingen) }\end{array}$ \\
\hline 2006 & $\begin{array}{l}\text { Kinetic correlation of spontaneous synaptic vesicle fusion } \\
\text { and evoked neurotransmission } \\
\text { Dept. of Membranebiophysics, Max-Planck-Institute for } \\
\text { Biophysical Chemistry, Göttingen }\end{array}$ \\
\hline
\end{tabular}




\section{LIST OF PUBLICATIONS}

Gliem S, Schild D and Manzini I (2009). Highly specific responses to amine odorants of individual olfactory receptor neurons in situ. Eur J Neurosci 29:2315-2326.

Gliem S, Kludt E, Schild D and Manzini I Mapping of water-borne odorants to subsystems of the olfactory system. In preparation.

Characterization of olfactory receptor gene expression in the olfactory epithelium of larval Xenopus laevis. In preparation. 